University of Louisville

ThinkIR: The University of Louisville's Institutional Repository

Electronic Theses and Dissertations

$5-2007$

\title{
The concept of peace : tracing its development through three historical periods in the west using artistic and literacy evidence.
}

Allan Berry McGuffey 1952-

University of Louisville

Follow this and additional works at: https://ir.library.louisville.edu/etd

\section{Recommended Citation}

McGuffey, Allan Berry 1952-, "The concept of peace : tracing its development through three historical periods in the west using artistic and literacy evidence." (2007). Electronic Theses and Dissertations. Paper 951.

https://doi.org/10.18297/etd/951

This Doctoral Dissertation is brought to you for free and open access by ThinkIR: The University of Louisville's Institutional Repository. It has been accepted for inclusion in Electronic Theses and Dissertations by an authorized administrator of ThinkIR: The University of Louisville's Institutional Repository. This title appears here courtesy of the author, who has retained all other copyrights. For more information, please contact thinkir@louisville.edu. 


\title{
THE CONCEPT OF PEACE: TRACING ITS DEVELOPMENT THROUGH THREE HISTORICAL PERIODS IN THE WEST USING ARTISTIC AND LITERARY EVIDENCE
}

$$
\text { By }
$$

\author{
Allan Berry McGuffey \\ B.A., University of Louisville, 1973 \\ M.A., University of Louisville, 1982

\begin{abstract}
A Dissertation
Submitted to the Faculty of the

Graduate School of the University of Louisville in Partial Fulfillment of the Requirements for the Degree of
\end{abstract}

Doctor of Philosophy

Department of Humanities

University of Louisville

Louisville, Kentucky

May 2007 
Copyright $\odot 2007$ by Allan B. McGuffey

All rights reserved 
THE CONCEPT OF PEACE: TRACING ITS DEVELOPMENT THROUGH THREE HISTORICAL PERIODS IN THE WEST USING ARTISTIC AND LITERARY EVIDENCE

By

\author{
Allan Berry McGuffey \\ B.A., University of Louisville, 1973 \\ M.A., University of Louisville, 1982
}

A Dissertation Approved on

March 20, 2007

by the following Dissertation Committee:

Dissertation Director 


\section{DEDICATION}

This dissertation is dedicated to my family,

Paula, Price, and Parker,

the 3Ps,

who have supported me tirelessly as I pursued

my third Humanities degree.

Love takes us where we need to go. 


\section{ACKNOWLEDGMENTS}

I cannot adequately convey my appreciation for the support I have received from my major professor, Dr. Mark E. Blum. His effort, always immediate and helpful, stands as a model for a true Mentor. He understood my project from the start, immediately seeing value in the description of my initial idea. Our mutual interest in the project never waned. I view his example as an expression of his extensive scholarly inquiry. We met on the ground of true friendship.

I must thank my other committee members to whom I also express my great appreciation. Dr. Annette C. Allen opened a door I had long ago closed. Her scholarly hospitality invited me into this new Humanities $\mathrm{Ph}$. D. program allowing me to fulfill a dream I'd long had. Dr. Carl R. Hausman has been a source of delight on many levels, none of which I want to name in favor of another. I am grateful to Dr. Osborne P. Wiggins for his intellectual example and his recognition of the Reality Maintenance Crew, a group to which he does not belong, thank goodness. Dr. Charles E. Ziegler to my benefit has made time for me during a busy semester.

I want to acknowledge two professors whose influence remains with me years beyond their presence in my life, Charles Breslin and E. R. Hagemann. The Graduate School awarded me a 2006 Project Completion Grant, which enabled me to take my exams and write my dissertation. Finally, S. Beth Atlee was a formative influence on my selection of a topic. 


\begin{abstract}
THE CONCEPT OF PEACE: TRACING ITS DEVELOPMENT THROUGH THREE HISTORICAL PERIODS IN THE WEST USING ARTISTIC AND LITERARY
\end{abstract}

\title{
EVIDENCE
}

Allan B. McGuffey

May 2007

The purpose of this dissertation is to suggest that peace is an idea that changes throughout the history of the west, rather than to show how nations may achieve peace or to define what it is. It begins as a concept the power brokers refer to or represent in their own terms. In Rome the concept of peace expressed the emperor's ability to end civil war. In Siena, the concept substantiated the Nine's claim that communal prosperity and absence of regional wars had happened during their rule. By the Westphalia period the power brokers began to realize the populace was entering the realm of political discussion with ideas of how to organize society in a way that would obviate the need for war. The absence of great war held for a couple of hundred years, without expunging the possibility of war's recurrence. During the world wars of the 20th century, the voice of the populace against war grew too strong for the culture to avoid. These periods are watershed points in western history. The socio-political structure of Rome followed republic with empire. The Sienese period emerged from the western medieval era. The Westphalia period followed the Thirty Years' War. The United Nations developed from the catastrophic $20^{\text {th }}$-century world wars. 
It is possible to view the development of the concept of peace through cultural achievements in the arts, specifically painting and literature. As the culture evolved, the expressions of artists and writers gained more capacity to anticipate the direction in which the culture would move regarding peace. As power brokers found they must recognize the expressions of the people who were gaining influence over their own lives and the cultural directions the people wanted to follow, western culture itself ultimately advanced to the point in the $20^{\text {th }}$ century when war was not the only acceptable response to international tensions.

The development of the concept of peace brought to the west an "atmosphere favorable to the activities of the mind." The concept of peace opened up the culture to a development of the west's collective qualities, which essentially were the measure of its humanity. 


\section{PREFACE}

When I began my dissertation I found a way to view the concept of peace as no one has done before. In my estimation, it is possible to use western artistic and literary evidence in their historiological and socio-political contexts to trace the development of the concept of peace. Doing so identifies the concept of peace as a manner, that is, a condition under which a quality of western humanity evolved. That quality is an indicator of the west's level of civilization. The western concept of peace developed from the era of the Roman empire until the mid-20 2 century when by the fact of the establishment of the United Nations the concept was represented as fully developed aspect of the western cultural socio-political framework.

I am able to deduce my claim because of my $21^{\mathrm{st}}$-century perspective on western culture and history. Arnold Hauser in his magnum opus, The Sociology of Art, notes that Henri Bergson "maintains that the present does not merely reveal hidden sides of the past but actually produces moments which were never present before, not only revealing them, but actually creating them for the first time" (527). Bergson's perspective, partially filtered through Hauser's own, intriguingly offers a possible reason why cultural historians can explicate, using historical research, the undercurrents of socio-political, artistic, and literary expressions in order to articulate in contemporary language and method the west's ability to evolve emotionally and humanely. 
The genesis of this dissertation came when I was searching for a topic for my semester paper in Humanities 661, Humanistic Studies I. It was Fall 2004 and I wanted to study an artistic artifact I could write about in an interdisciplinary way. Having an equal desire to write about something I had not previously studied, I asked my professor for a suggestion. She mentioned the Allegory of Good and Bad Government by Lorenzetti. "Have you heard of it?" I had not.

The painting, a fresco, dated from a period about which I knew little. I had little reason to expect the painting would later fascinate me. I could tell the fresco turned on the image of Peace near the center of the primary panel. The paper I wrote discussed the way in which the Sienese power brokers, the Nine, had commissioned the fresco to serve as positive propaganda for the success of their rule, one point being their ability to maintain peace in a region known for conflict among rival city/states.

I found intriguing the idea of peace as a propaganda point. It occurred to me that I could also employ a similar perspective to view the Forum of Augustus in imperial Rome. However, there seemed to be a difference in the effect each artifact achieved on behalf of the power brokers in each era. In Rome, the emperor Augustus seemed to want to declare the existence of a state of peace within Rome even though the empire had to maintain its hold on the territories it had accumulated in its republican phase. The Forum served as a reminder of Roman achievements preceding his rule. As our class surmised from discussions, the usefulness of the Forum was to legitimize the rule of Augustus in the presence of reminders of the great Roman past. The Lorenzetti fresco in The Sienese era seemed to play such a role in the legitimizing of the Nine less than 20 years before the 
end of their own rule. The fresco links the Nine to previous Sienese governments as well as Rome itself in the shared heritage of a descent from Remus.

The issue of peace has interested me for decades. However, I always equated it with struggles relating to wars and strife contemporary to my lifetime, a myopic view to be sure. The possibility of other periods to balance those of Rome and Siena occurred to me when I realized I was limiting my concentrating to socio-political orders on either side of the Middle Ages. The Westphalia and the $20^{\text {th }}$-century eras struck me as equally significant post-war periods for western culture as the Roman and Sienese periods. One may always discuss the results of such periods historically. I wondered if there were artworks in each of the two later periods that might speak to the culture's move to the achievement of peace in the west. After I discovered Rubens' painting, Horrors of War and Picasso's two post-war murals, War and Peace, I looked for literature that might serve as cultural evidence that would allow me to discern the movement in the west toward peace. I found them in The Aeneid, The Divine Comedy, and Four Quartets. The Westphalia period ushering in the European conglomeration of nations gave me the work of Hobbes, Locke, and Rousseau. My conception, while not entirely parallel, was complete in my mind.

I decided to use Rome as a base period, rather than a full period for study, because the empire's reach established the geography on which the development of the concept of peace would occur. My concern, then, was Europe, that is, western culture. In the development, it is easy to see the movement from the power brokers' own control of the concept of peace to the slow acquisition of control of the concept of peace by the populace through the agency of their own voice and desire. The three forms of evidence I 
employ, the historical, the artistic, and the literary, present me with ways of thinking about the culture and the emotional impact of events on the populace of the eras. 1 employed the thinking of Arnold Hauser, expressed in his book The Sociology of Art, to help me speak to the idea of generational points of view on the development of the concept of peace. The establishment of the United Nations after World War II seemed to be an ideal period with which to end. The United Nations was an organization charged with the task of maintaining peace, which implied the west had achieved peace. In actual fact, I think the west had achieved the ability to define peace and work from there. 
TABLE OF CONTENTS

PAGE

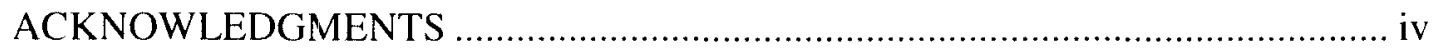

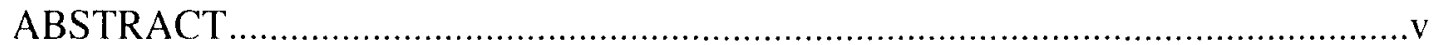

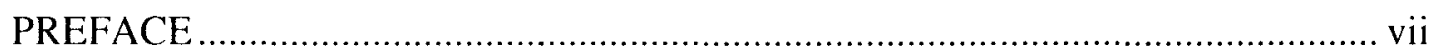

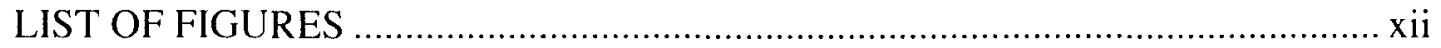

CHAPTER

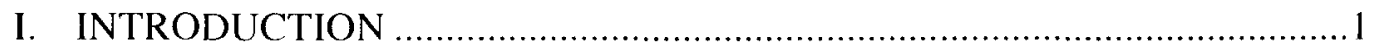

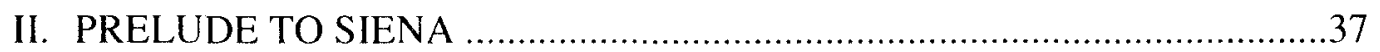

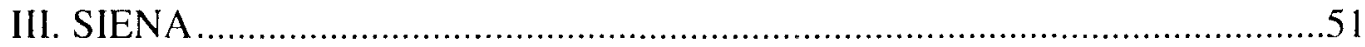

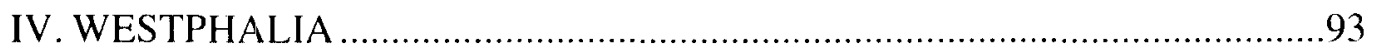

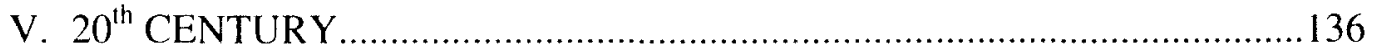

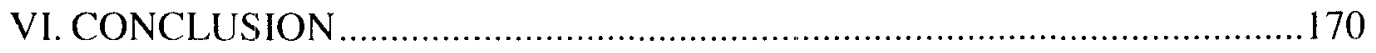

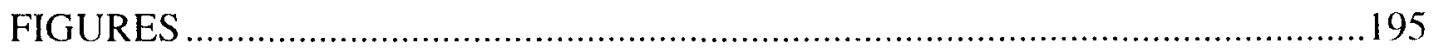

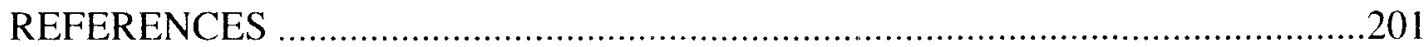

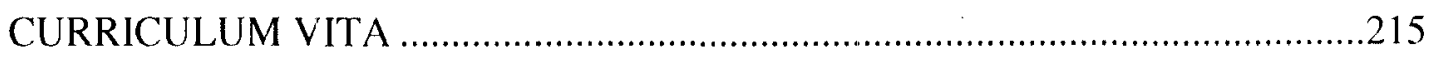




\section{LIST OF FIGURES}

FIGURE

PAGE

1. Allegory of Good Government 195

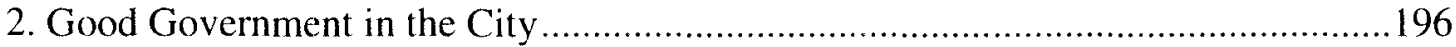

3. Good Government in the Country........................................................... 197

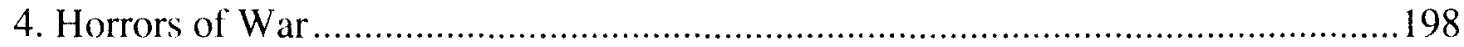

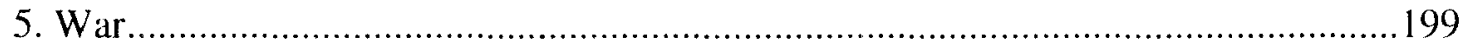

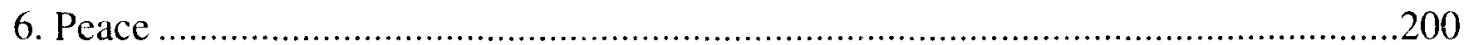




\section{CHAPTER I}

\section{INTRODUCTION}

When we think about peace, we also think about the conflicts that caused the need for achieving and maintaining peace. What will it take to end a conflict? What resolutions will we accept as the true end of the conflict? What is the meaning of the peace? What structures do we establish so that peace will take root initially and thrive in the future? Recent discussions of peace define the term in complex ways that generally situate the issue within the broader subject of conflict studies and resolutions. Conrad G. Brunk cites "the primary concern of Peace Studies [as understanding] how conflicts among human beings arise, what causes them to become harmful for some or all parties, and what means are most likely to deal with them in less harmful ways" (17). In the transformation of ideas into acts, the applicability of conflict-resolution strategies depends on the relations between two parties with a dispute. On the scale of nations and the multitude of subtle problems that may daunt efforts at peace, new ideas, such as, Roland Paris' may help. He notes "limitations of the liberal peace thesis itself" (151). It is his contention that before liberal approaches to government, such as, democracy, can be grafted successfully onto another political system, efforts at resolution should include the creation of an order on which democracy can first function.

The history of humankind presents a history of conflicts. Some conflicts grow heated, turning into wars; some remain cool, but tense. In the west, conflict has seemed 
continuous even though the cultural mind has contained an idea of peace, at least, since the time of the pax romana of the Roman empire. Throughout western history the contrast of the prevalence of war with the difficulty of living in peace spurs inquiries into the reasons for the difficulty of attaining a lasting peace. Nations in the west have fought war after war. Even so, the west has had a strong desire for peace. It is difficult at times to reconcile an awareness of both sides of the issue. Until one realizes the drive to war results from the wills of governments clashing and the will to peace emerges from the desires of the populace to take governments to task for their wars, the desire for peace presents problems.

Peace has developed its meanings and uses through different eras in the west. One may view the roots of peace in the history of the west, in which the meaning of the term, peace, seems to shift. More recently, in the $1960 \mathrm{~s}$, people, who saw iconoclastic televised images of various events designed to express an urgency for a resolution to a conflict, remember citizens marching or rallying for the cause of peace, for example, in relation to war in Vietnam or civil strife in the American South. Today, people's images of peace efforts may focus on African nations where questions of civil wars and genocides remain unresolved. In this case, the meaning of peace encompasses both the nature of the conflict and its resolution. Usually the official discussions of solutions to these world problems occur at the United Nations, whose charter established the organization as a peacekeeping institution. Again today, the world watches as the need for peace changes as well as the resolutions to the problems of human strife that prevent peace.

This dissertation shows that the governments of the periods surveyed and, by extension others, continually exercised the power of waging wars and declaring peace. 
Their power focused on their own interests over those of their people. The powerful took what they could get from many sources. This kind of grabbing for greater power created enough of a disparity in power for the populace eventually to express its disapproval of policy. The dissertation offers details in increasing degrees from all the periods to show that as the eras passed, it was possible to select artistic and literary evidence to indicate the growing will of the people to achieve peace. The arts cause scholars to view peace in a way that helps the culture comprehend what it wants to express in given eras. The question of socio-political order as a basis for peace seems critical today. Having found its way to a developed concept of peace, the west embodied the concept in a building that houses the United Nations, an organization established to oversee the maintenance of peace in the world. Since its inception the United Nations has monitored efforts of peacekeeping around the world. With both successes and failures to its credit, the United Nations represents the developed concept of peace, which is a result of the will to peace in the west.

The purpose of this dissertation is to suggest that throughout the history of the west from the period of the Roman empire through the period when the United Nations is established after World War II peace is an idea that evolves. The dissertation does not show how nations may achieve peace or how they define what it is. It begins as a concept the power brokers refer to or represent in their own terms. In Rome the concept of peace expressed the emperor's ability to end civil war. In Siena, the concept substantiated the Nine's claim that communal prosperity and absence of regional wars had happened during their rule. By the Westphalia period the power brokers began to realize the populace was entering the realm of political discussion with ideas of how to organize 
society in a way that would obviate the need for war. The absence of war held for a

couple of hundred years, without expunging the possibility of war's occurrence. During

the world wars of the 20th century, the voice of the populace against war grew too strong

for the culture to avoid. These periods are watershed points in western history. The socio-

political structure of Rome followed republic with empire. The Sienese period emerged

from the western medieval era. The Westphalia period followed the Thirty Years' War.

The United Nations, whose charge is to maintain peace, developed from the catastrophic $20^{\text {th }}$-century world wars. Selected artistic and literary evidence from each period indicates the strengthening popular voice throughout these historical periods.

Discussions of peace apply to a wide variety of historical and political situations.

In the past 40 years and farther back to 1795 when Immanuel Kant published Perpetual

Peace, much has been written in public, diplomatic, and scholarly realms about peace

initiatives among nations, peace movements among the citizens within and between

nations, and efforts to introduce peace into some of the most difficult socio-political

arenas in the world. Peace talk covers grand thinking on nonviolence and social change,

among many other aspects of international social, political, economic, and human

cooperative gestures. ${ }^{1}$ This dissertation will not deliberate on those aspects of peace

\footnotetext{
${ }^{1}$ Discussions of peace are ongoing and the literature is enormous. Among the sources one may turn to in order to understand discussable issues in the past 200 years include the following. Immanuel Kant in Perpetual Peace was "the philosopher of the peace movement," according to Edwin D. Mead, who suggests in his Introduction to the English translation of Kant's volume that the Kantian notion of universal peace accompanies the idea of the universal republic. The United States and England come closest to putting this movement into practice. For a discussion of the Church and its war and peace practices during the Hundred Years' War, see Ben Lowe's 1997 volume Imagining Peace: A History of Early English Pacifist Ideas, 1340-1560. S. C. Vestal's The Maintenance of Peace from 1920 studies the maintenance of peace within nations and among nations in Europe through the era of World War l. Beitz and Herman's Peace and War anthology from 1973 explores systems of war along with approaches to the building of peace in the world. Recent studies include a 1987 anthology by Saul H. Mendlovitz and R. B. J. Walker, Towards a Just Peace: Perspectives from Social Movements. This work surveys discussions on "global structures and processes that affect people everywhere and the social movements that arise in highly specific situations in response to highly specific problems" ( $v$ ) in which the authors assert that "even the
} 
discussions. Instead, it will look at the development of the concept of peace as it exposes a simple human development in the west. Examining the concept of peace provides a measure to assess the strides western humanity took to civilize itself over nearly two millennia of socio-political striving and conflict. A civilized humankind bears responsibility for its motivations and actions. This dissertation assumes the term peace has referred differently in succeeding historical periods in the west. Therefore, the term is regarded conceptually as unformed, undefined, and open to use by those whose speech expresses power. This dissertation will indicate how the concept of peace developed a voice among the populace as it gained its own power of expression.

The eras chosen for this dissertation exemplify points in western culture where movement in society, politics, literature, and painting demonstrated shifts in the strengths and influence of the power brokers compared to the populace they ruled. During these periods, the result of those shifts was reflected in the ascendancy of the concept of peace as it entered the consciousness of the populace. That consciousness signaled cultural fault lines and stimulated the popular will to achieve peace. The concept of peace developed along these cultural fault lines bringing about progress in the ability of western culture to realize that it could achieve peace, an achievement that emerged in the $20^{\text {th }}$ century. The developed concept of peace was embodied in a concrete institution, the United Nations. Even though the United Nations building housed another governing body of power brokers, the institution governed no single populace. Its focus covered the world. The scope of the dissertation ends at that point. century movements, social structures, developments, and challenges to such definitions. 
The development of the concept of peace in the west has depended on the emergence of the voice of the populace from its muted form during the Roman empire in the Augustan Age between 27 b.c.e and 14 c.e. through the post-World War II period when the United Nations was firmly established as a world institution with its roots spread in the soil of European, hence western, conflicts. It is possible to comprehend the development of the concept of peace as one measure of the degree of civilization reached in western culture. By examining in three watershed historical periods the achievements that evolved in the western socio-political, artistic, and literary traditions that were established during imperial Rome, one may ascertain that peace was employed first as a concept at this historical point in the west. Peace was then introduced by power brokers to promote their ideas for their own successful rule over their citizens. After a shift in the influence of the populace, by the $20^{\text {th }}$ century its will forced western power brokers to incorporate into the maintenance and control of their own societies the strong popular will and its demands for peace and an end to war.

The watershed periods in the development of the concept of peace after imperial Rome, include Siena during the rule of the Nine from 1271-1355 and the early-Modern period after the event of the Treaty of Westphalia in 1648. For the purposes of this dissertation, this Westphalia period, focusing on no one European location, contains the time of Rousseau`s influence beginning in 1760. The fourth period in the development of the concept of peace begins after World War I and lasts until the establishment of the United Nations. At this point, the dissertation ends. The United Nations was established as an institution directed by its charter to maintain peace in the world. Therefore, for western culture, the concept of peace in the west had developed. 
From the literature of Rome. Siena, and the $20^{\text {th }}$ century, poetry reflects the sociopolitical shape of each period. Virgil's work formed a baseline in imperial Rome, Dante followed in Tuscan Florence, and T. S. Eliot culminated in $20^{\text {th }}$-century England to show a development of literary thinking that reflected their eras' places at particular moments in the history of the west. Similarly, the painting of Ambrogio Lorenzetti (1339) in Siena, Peter Paul Rubens (1638) near the end of the European wars leading to the Treaty of Westphalia, and Pablo Picasso (1952) in $20^{\text {th }}$-century France expressed through paintings their depictions of states of affairs in their eras. However, in the Westphalia period, there was no poet whose work was commensurate with the poetry of the other three eras. Instead, the literature of political thinkers, Thomas Hobbes, John Locke, and later JeanJacques Rousseau helped shape the different social structures that emerged after the Treaty of Westphalia. Western culture had to re-establish its socio-political framework. The Treaty ended the Thirty Years' War and brought about the collective socio-political systems known thereafter as European. In this period, there was a shift from the previous condition where the populace had been ruled without being able to contribute much of its own voice in the political systems. In the Westphalia period, the power brokers discovered they had to allow the voice of the populace into the socio-political dialogue. The appearance of the literature of Hobbes, Locke, and Rousseau indicated the shift. In imperial Rome, the artworks that conveyed a sense of the Pax Romana and what it meant were largely architectural rather than literary. This architecture provided symbolic places for the patrician class to meet and conveyed the power brokers' notions of civic order and their legitimization by reminders of past legacies. 
The history of the west defined itself through a slow civilizing process. On the one hand, western culture had erected a veneer of civilization, the effect of which had been attributable to refinements in the products of creative human endeavors in politics, art, thought, and literature. On the other hand, the culture had experienced continual struggles, hardships, and terrible wars. Since Roman antiquity, the steepest hurdle western culture had mounted was the problem of human nature, which drove the culture's successes and failings. One of the greatest successes the west claimed was the endurance of progress in conceiving conceptual meanings of human actions and needs, then sticking with the drive to achieve positive results. Throughout the history of the west from the Roman empire on, the procedures of persons in the west was led by the artistic sensibilities that appeared in specific eras in the culture. Even though the human being was from the start anthropologically constituted for aggression and assertion of needs, the culture reached a point where a final civilizing urge asserted itself. The development of the concept of peace, that civilized assertion, took nearly two millennia to reach the point where it gained a foothold strong enough to establish a framework in which the concept of peace could grow. The concept always addressed two sides of the coin in a balancing act between the tranquility (peace) the concept was achieving and the destructiveness (war) the concept was attempting to weaken. In each historical era, the culture faced new struggles. Yet, from every set of issues, the culture provided solutions to issues of the previous eras. Such growth permeated the culture emerging as traces encoded in the artistic and literary achievements of their eras. Each era's growth accumulated to the point in the west where the desire among the populace to achieve peace strengthened into a will. One such expression came in the aftermath of World War II when three ranking 
officers in the United States Armed Forces concluded that "if man does find the solution for world peace it will be the most revolutionary reversal of his record we have ever known" (War Reports 152). The development of the concept of peace would seem unlikely to happen. Auguste Briand, the 1926 Nobel Prize Laureate in Peace and one of the authors of the 1928 Kellogg-Briand Pact stated "if the idea of peace is to reign among the nations, we must not shut our eyes to the fact that there are certain poisonous influences persistently at work. Not all men are enamoured of peace" (53).

Each period expressed different viewpoints on the path to peace or war in visual and verbal language particular to its own time. The three periods after Rome operated as cultural descendants passing on the western characteristics and facilitated an accumulation of reflexive knowledge about the makeup of the cultural mind. Those three cultural periods emphasized the prominence of an awareness of different human characteristics until the end of World War II showed that the survival of the west and the world needed the structure of the United Nations to direct human efforts to the achievement of peace. Each of the three periods exposed and refined different aspects of the concept of peace increasing the scope of the concept's applicability to the humanizing of western culture.

Dante in De Monarchia spoke to the balance he prescribed for all levels of the culture of his period. His vision encompassed a unity of body, mind, and spirit he found to be crucial elements for his period. Additionally his vision pointed ahead to later historical periods in the west when even through the $20^{\text {th }}$ century the west still was discovering similar unities in the language and vision of that later period. 
It has been sufficiently shown that the work proper to the human race, taken as a whole, is to keep the whole capacity of the potential intellect constantly actualized, primarily for speculation, and secondarily...for action.

And since it is with the whole as it is with the part, and it is the fact that in sedentary quietness the individual man is perfected in knowledge and in wisdom, it is evident that in the quiet or tranquility of peace the human race is most freely and favorably disposed towards the work proper to it.... Whence it is manifest that universal peace is the best of all those things which are ordained for our blessedness (Dante De Monarchia [1312-1314] 641).

Hugo Grotius introduced the tenets of Natural Law and Right Reason as foundational elements on which later authors from the populace stood after the Treaty of Westphalia and rose to positions of influence in the face of power brokers who did not want to welcome their voices.

For God himself hates violence, and will not have us to grow rich by rapine, but by lawful gains. That abundance, which is the fruit of unrighteousness, is an abomination. The air is common to men, the earth also, where every man, in the ample enjoyment of his possession, must refrain from doing violence or injury to that of another.

Now the law of Nature is so unalterable, that it cannot be changed even by God himself (Grotius [1625] 20).

Konrad Lorenz in his work, On Aggression, based his conclusions on the findings of thinkers and writers such as Sigmund Freud, whose consciousness of humankind's aggressive instincts, and T. S. Eliot, whose concern with time, helped direct civilized thought during the final stages of the development of the concept of peace. In the early decades of the $20^{\text {th }}$ century, a Modernist perspective broke forth to show that beyond nationalistic differences, humankind shares a complex commonality in its basic soul.

Aggression, the effects of which are frequently equated with those of the death wish, is an instinct like any other and in natural conditions it helps just as much as any other to ensure the survival of the individual and the species. In man, where our efforts have caused an over-rapid change in the conditions of his life, the aggressive impulse often has destructive results (Lorenz [1969] x). 
From such a viewpoint after many attempts in the west in the early $20^{\text {th }}$ century to establish institutions of peace, emerged the United Nations, whose creation marked the developed concept of peace.

The development of the concept of peace offered a narrative of the western societies that this dissertation identifies as claimants to the idea. As such, one may situate the concept of peace in the place in which the concept reveals itself, in the manner in which the concept was conducted, and in time, which allowed the concept of peace to gain the shape it needed relative to the relationships between the power brokers and the populace within a particular historiological, socio-political framework. That is, three unities of place, manner, and time allow one to view cumulatively the societies in which the concept of peace unveiled and developed itself. The socio-political framework of each era brought a set of changes to the concept of peace, causing its development. By the establishment after World War II of the United Nations, the development of the concept of peace had evolved in the intellectual framework of the west to directly affect the socio-political structure in $20^{\text {th }}$-century Europe.

Imperial Rome, providing the base point of the western social order, instantiated the development of the concept of peace by rooting it in a socio-political framework. From this framework the concept drew its range for growth throughout the centuries and established its expression of the qualities of humanity that allow the development of the concept of peace to parallel the civilizing of western humanity. One may estimate that the 
very nature of western humanity emerged in the struggle to counteract with the necessity of peace the western tendency to prosecute war after war over the centuries.

When considering the unities, the causation in the framework from category to category is apparent. The place, location, of each era's contribution to the development of the concept of peace in the west occurred in roughly the same geographical area, providing a clear western framework for the development of the concept of peace. The geography under imperial Roman influence roughly established the area known as the west. To the Romans, this area was the "world." In early-Renaissance Siena, the area of the place had shrunk to include just the area around the region of Tuscany in current-day Italy. However, after the Treaty of Westphalia was signed, the area of the place expanded again to include Europe. By the end of the $20^{\text {th }}$ century, the area of the place of European influence again covered much of the area of the Roman empire. The focus of European affairs irrevocably had influenced the world through the agencies of the world wars. In the $20^{\text {th }}$-century, the expanse of the "world" had stretched to global proportions. The concept of peace having developed into the agency of a world organization, the United Nations, for the maintenance of peace also stretched the proportions of its purview.

The manner in which the concept of peace was conducted was critical to its development. In imperial Rome, the emperor Augustus declared the Pax Romana and identified it by closing the doors to the Temple of Janus. The Pax Romana established peace as a concept that evolved to bring change to the socio-political framework in the west. Gerald Zampaglione in his work, The Idea of Peace in Antiquity, mentioned three important socio-political characteristics of the Pax Romana. First, the empire had achieved great power. The relations the empire established between Rome and its 
external territories contributed as a determinant to Roman socio-political framework. The emperor could maintain the quality of life within the city of Rome. Second, the empire established an early instance of a continuing European problem "the liberation of the body politic from the shadow of civil war." Finally, crucial to the ability of the west to develop the concept of peace was "the formation of an atmosphere favorable to the activities of the mind" (135). In the west, these three characteristics became the basic determinants for the concept of peace. They evolved concurrently with the historiological progression of the development of the concept of peace through the re-appearance of periods of peace after great wars as they occurred through the centuries until the end of World War II.

In the Sienese period, the end of regional wars ushered in a period of peace in the region of Tuscany in present-day Italy. The peace lasted until the raids of the mercenary companies and the later religious wars that followed the rule of the Nine. The manner in which the concept of peace was conducted during the rule of the Nine in Siena between 1271-1355 depended on the rivalries among the Tuscan city/states that strengthened the propensity of the power brokers to focus energy internally on themselves as providers of the communal peace. While there were no wars, the region, however, suffered periodically from factional tensions. The concept of peace developed because Siena during the period of the Nine's rule did not need to guard itself continually from the rivalries with Florence and Padua. The absence of war as well as the ability for the Nine to create a structure for business and the arts to flourish in Siena established a sociopolitical framework where the Nine could govern a commune whose small size kept them close to the civic group, the Noveschi, from which the Nine was selected. 
In the Westphalia period, the duration of the concept of peace lasted from approximately 1648 through 1870 . Wars prosecuted began and ended within the aegis of these rules. In that time, individual nations ruled themselves, post-war national and international relations based themselves in diplomacy and mutual need as the sociopolitical framework relaxed from the shadow of 'Thirty Years' War. The concept of peace developed in this period, because the Treaty of Westphalia established the need for a structure of diplomacy to operate among societies. The socio-political framework of the time allowed for writers throughout the long period not affiliated with the power structure to begin to address the organization of society directly to an audience that included the populace. Those writers addressed the issue of peace as an outgrowth of the sociopolitical framework. They had a precursor in Hugo Grotius, who in 1620 during the war addressed in his book, Rights of War and Peace, the laws of human nature that governed even in time of war. During the initial years after the Treaty, there were efforts at establishing constitutionalism. Even though those efforts at the time failed to succeed-as with Cardinal de Retz in the Fronde-the will of the people gained increased influence in the culture.

In the post-war, $20^{\text {th }}$-century period, individual nations regained the ability to rule themselves, and post-war international relations were based on diplomacy, mutual need, and deterrence. In Europe, later regional conflicts did not threaten the socio-political stability of the continent. A world organization had been established and charged with the task of maintaining peace in a headquarters structured for the oversight of worldwide security issues. In this final period of peace the socio-political framework of the west as well as the world was liberated from the shadow of world war, which allowed a renewal 
of the idea of a post-war atmosphere favorable to the activities of the mind. The culture began to see intellectual advances in all fields.

The third unity, time, enabled the generational duration of the manner in which the concept of peace developed relative to events that changed thought. Each period indicated a mode of operation for the concept of peace in its particular historiological period. In the beginning, imperial Rome established the western socio-political order, especially when the patrician class of rulers declared the existence of the Pax Romana. The definition of the concept of peace seemed relative to the wishes of the power brokers, mainly the emperor Augustus. The Sienese period contributed the maintenance of order, which was as much a maintenance of the socio-political framework as a maintenance of the government. The Westphalia period allowed the west to gain the benefits of order, opening a place in the socio-political framework, reluctantly out of necessity, for the voice of the populace to emerge into the socio-political equation. Finally, the post-war, $20^{\text {th }}$-century world saw the western concept of peace developed into an organization of order in the guise of the United Nations.

Secondary in this dissertation to the three unities of place, manner, and time, an intellectual understanding of the historical movement of each period hinges on the presentation of emblems to represent the historiological unity of the period. These emblems introduce cultural abstractions produced in the socio-political framework of each period by the artists and writers whose voices established the influence of the populace over the centuries. In imperial Rome, the emblems for the concept of peace were the Forum of Augustus, Augustus's Ara Pacis, and Vespasian's Templum Pacis, all structures of official Rome. The concept of peace was used by the power brokers in two 
ways: 1) politically as the Pax Romana; 2) symbolically by closing the doors to the Temple of Janus in order for the concept of peace to be useful to the emperor and the ruling class. The concept did not extend throughout the empire. In Siena, the emblems included the Ambrogio Lorenzetti fresco cycle, Allegory of Good and Bad Government. The concept of peace was used as propaganda, identified and claimed by the Nine. The concept was useful to the Nine and the rest of the power brokers, and the concept did extend through the commune, chiefly into the business class. In the Westphalia period, the emblems was the painting by Peter Paul Rubens, Horrors of War. In this historiological period, the concept of peace was used by the power brokers who still wanted to maximize their rule. But, efforts at a better organization of the socio-political framework arose. Philosophically the writers emerging from the populace at this time began to discuss issues of the human being and his inner nature, depicting the need in the socio-political framework for an order that penetrated into the lives of the populace. Through the efforts of the writers and thinkers in the populace, natural law and right reason allowed ideas to manifest themselves regarding the question of the human being in relation to the state. In the post-war, $20^{\text {th }}$-century period, the concept of peace arose between the world wars in the form of peace movements the largest of which was the League of Nations. The United Nations became the official organ of peacebuilding after World War II. Peace efforts were taken over between the world wars by representatives of European nations, especially those meeting under the auspices of the League of Nations. Peace efforts were taken over after World War II by the United Nations, which represented the developed the concept of peace in the following sense. As an organization, the United Nations was chartered with the task of maintaining peace among 
nations. Those nations were not limited to European ones. The United Nations' Charter

extended peace efforts to the maintenance of peace among world nations.

Table 1 indicates the narrative of the western societies that emerges as this

dissertation explicates the development of the concept of peace.

Table 1: The Concept of Peace from Rome through the United Nations: Its Implications for Societal Governance

A) Rome

- Place. The geography under Roman influence roughly establishes the area we know as the west, the "world"

Imperial rule: The societal framework for peace

- Manner in which the concept of peace is conducted:

- International relations based on the great power achieved by the empire

- The liberation of the body politic from the shadow of civil war

- The idea of the formation of an atmosphere favorable to the activities of the mind

Emblems for the manner in which the concept of peace is conducted: Visual, the Forum of

Augustus. Augustus's Ara Pacis, and Vespasian's Templum Pacis; Literary, Virgil's

Aeneid

- Time (Generational duration of the manner in which peace is conducted):

- Roman empire emerges from Roman republic (2.3 b.c.e.)

- Strength of governance as a result of stahility of imperial socio-political order

- Arts indicate who holds power

- The Forum of Augustus establishes a Roman legacy for Augustus in the statuary representations of exemplary citizens from Rome's past

- Virgil's Aeneid depicts the strength (virtus) of the empire

B) Siena

- Place. Geography covers a small area, the region of Tuscany near Rome

Commune: Rule by selection to governing group from a larger group of civic and business leaders

- Manner in which the concept of peace is conducted:

- End of regional wars

- Rivalries among the city/states strengthened the propensity of power brokers to focus much energy internally on themselves as providers of the communal peace. There was regional tension produced from factions

Emblems for the manner in which the concept of peace is conducted: Visual, the architecture in the central plaza of Siena, including the Palazzo Pubblico, which contains the frescoes painted by Ambrogio Lorenzetti as well as other commissioned artworks; Literary, Dante's Commedia. Marsilius' Defensor Pacis

- Time (Generational duration of the manner after which peace is conducted relative to events that change thought):

o The Nine begin their ruk in 1271

- Strength of governance as a result of stability of socio-political order. Power brokers drawn from merchant class 
- Arts indicate the lincage of power

- Palazzo Pubblico contains artwork that depicts the lineage of rule

- Dante's Commedia desires lost paradise in unity of hody, mind, and spirit

Events (early-Renaissance) that change thought:

- Black Plague 1348

- Emperor Charles IV of Luxembourg arrives in Siena in March 1355

- Mercenary companies and marauders appear from 1340s-1399

- French religious wars in region 1562-1598

C) Westphalia

- Place. Geography of European influence again covers much of the area of the Roman empire Nations: Existence of "Europe" forced the issue of nations and the necessity for a dual focus on

intranational and international relations

- Manner in which the concept of peace is conducted:

- Individual nations rule themselves

- Post-war international relations based on diplomacy and mutual need

- The liberation of the bodies politic from the shadow of Thirty Years' War

- The Treaty establishes the need for structure for diplomacy among societies

- Writers not affiliated with the power structure hegin to address the organization of society directly

- Writers begin to address the issue of peace as an outgrowth of political order

- Grotius during the war addresses the laws of human nature that govern even in time of war

- The will of the people gains increased influence even through defeats as with Cardinal de Retz in the Fronde

Emblems for the manner in which the concept of peace is conducted: Visual, Rubens'

Horrors of War; Literary, Hobbes' Leviathan. Locke's Two Treatises of Government,

Rousseau's Confessions.

- Time (Generational duration of the manner after which peace is conducted relative to events that change thought):

- Trealy provides the structure for nations to interact and negotiate peace

- Stability of national and international governance

- Arts foreshadow direction of Modern socio-political order

- Rubens reflects the need for socio-political openness (1638). The Treaty resolves this need

- Hobhes, Locke. Rousseau as members of the populace develop thought that opens up political thinking

- Voice of the populace pushes to be heard

- Social action: Cardinal de Retz and the Fronde (1653)

- Political treatise: Hobbes Leviathan (1651); Locke Two Treatises of Government (1690)

Events (early-Modern) that change thought:

- Treaty precipitates a long (relative) peace among nations in Europe and precipitates a constitutionalism effort that does not hold

- Rivalries among European nations 1871-1914

- The Hague Conference creates a World Court 1899

D) Post-war $20^{\text {th }}$ Century

- Place. Geography of European influence again covers much of the area of the Roman empire Nations: Decisions of peace rely on national and international decision-making 
- Manner in which the concept of peace is conducted:

- Individual nations rule themselves

- Post-war international relations based on diplomacy and mutual need

- The liberation of the bodies politic from the shadow of world war

- The idea of the post-war renewal of an atmosphere favorable to the activities of the mind (the United Nations, deterrence after atomic bomb)

- UN points outwardly to the World, the rest of the world.

Emblems for the manner in which the concept of peace is conducted: Visual. Picasso's War and Peace; Literary, T. S. Eliol's Four Quartets

- Time (Generational duration of the manner after which peace is conducted relative to events that change thought):

- The United Nations: symbol of the developed concept of peace

- Stability of international community because of developed concept of peace

- Arts indicate factors in the equation of international order

- Picasso's murals, War and Peace reflects the need to focus on the co-existence of two realities

- Eliot expresses wartime as loss of time, of progress

Events (Modern) that change thought:

- Treaty of Versailles and League of Nations failures lead to World War II

- Munich Pact with Hitler fails because nations apply Treaty of Westphalia throughout rather than Treaty of Versailles

- Nuclear armaments

This dissertation suggests the utility of the concept of peace provided for the culture two aligned benefits: 1) The concept marked the progress of the development in western culture of the symbiotic relationship between the ruling-class power brokers and the populace whose influence increased throughout the history of the west until the power brokers were forced to forestall the use of war as the standard method for responding to international tensions on the European continent; 2) The concept provided a useful lens through which to view the development of humanity in western civilization. It is possible to view the development of the concept of peace through cultural achievements, such as, the arts, specifically in painting and literature. As western culture evolved, the expressions of artists and writers gained more capacity to anticipate the direction in which culture would move regarding peace. As power brokers found they needed to recognize the expressions of the people who were gaining influence over their own lives and the cultural directions the people wanted to follow, western culture itself ultimately 
advanced to the point when war ceased being the only acceptable response to

international tensions. Each period used the perceptions of its own time to detail the ideas that structured the period's environment.

Public policy changed from period to period, not only from an evolution of the governmental viewpoint. In fact, the governments of each period had their own powers and special interests to protect. In parallel development, the activation of the popular will also evolved as a factor to protect. Even though the activation happened slowly, it did finally begin, especially after the Peace of Westphalia with the expansion of regional hegemonies into European nations that attempted to stabilize their sovereignties. The artists simultaneously heralded the coming dissatisfactions with the quality of life throughout Europe during wars. With such an artistic avant garde, even the populace gained the expression of strengths they continually struggled to keep. As happens today, governments still did not easily relinquish their viewpoints. For example, even after World War II saw the establishment of the United Nations, an organization that perhaps held a promise for governance or supervision of peace for the world, one must remember the distribution of power was established based on the outcome of World War II. In the $20^{\text {th }}$ century, the west and the world had the opportunity to remain skeptical as they placed a degree of qualified hope in the new organization of governments.

Arnold Hauser in his work, The Sociology of Art, examined linkages in western creativity between artists and the culture within the context of the socio-political framework of the times in which the artists lived. Artists, as Hauser suggested in The Sociology of Art, were products of their generations and could act in no other way but 
with historic logic, and produce no other object, except that which the culture needed to have expressed at the time the work appeared and that which the culture was directly capable of viewing meaningfully. The artist for Hauser is "the product of the social soil in which he is rooted... Everything is not possible at every moment... we need the right talent in the right place at the right moment" $(28)$ in order to make human progress. For this reason, it is possible to trace the development of the concept of peace through artworks, such as, paintings, and to comprehend the culture's commitment to the concept of peace. The frescoes of Ambrogio Lorenzetti in Siena in 1339, the Horrors of War painting by Peter Paul Rubens in 1638, and the War and Peace murals by Pablo Picasso in 1952 each depicted views of peace, war, and governance that expressed the tenor of their historical periods in ways that exposed the emotions the populace felt at those particular moments and addressed exact stages in the development of the concept of peace.

Poets within western culture provided readers access to natural allegiances within the framework of humanity. For example, the development of the concept of peace was traceable in poetry from The Aeneid through The Divine Comedy to Four Quartets. The tracings revealed a movement from Virgil's depiction of a man driven off course and ultimately into a state of war that resulted in the founding of Latium (Rome), giving him a place, the significant location from which the culture would spring. From Dante's achievement, the early Renaissance readers discerned a vision of the unity of body, mind, and spirit newly formulated, adding dimension to the place already firmly established by Virgil. In the $20^{\text {th }}$-century era, T. S. Eliot as an artistic heir to Virgil through Dante was able to communicate a sense of the descent of the cultural framework. Readers realized 
that the agony of war abides even in the same geography described by Virgil, Rome being the seed from which European culture spread. The $20^{\text {th }}$-century agony of war and its perception in time as agonizing was great enough to provide the final urge for the concept of peace to develop. Even so, Eliot likely wound up able to view the state of affairs in the $20^{\text {th }}$ century as hopeful due to movement forward in time and the knowledge that the concept of peace did exist. Other allegiances of which the poets reminded the culture included natural senses of place, spirit, and time without which the perception of the concept of peace would have failed. The multi-vocality of thinkers who helped organize the socio-political framework characterized the Westphalia period. Treatise authors, such as, Hobbes and Locke, in the aftermath of Westphalia represented the changing socio-political perspectives on the alignment of nations and populations. This multi-vocal cultural characteristic became part of the western socio-political mindset and continued through the $20^{\text {th }}$ century.

Detecting and shaping a definition of the concept of peace in the west requires the application of a viewpoint across differing cultural periods to assess questions of cultural order and artistic expression. The concept of peace as it developed from antiquity forward into the Modern era developed according to the difference in each era's relationship between the ruling class and the populace. The identity and socio-political status of the definers shifted as well, creating fundamentally different needs for the concept of peace to address.

Broadly speaking, an absence of war defines peace, but this definition is unsatisfactory in its profound simplicity. When one talks about peace, what remain in 
mind are the subtleties and shadings that underlie the term. Peace is a concept that has been a cultural reference point for two millennia even though it does not necessarily refer to the same thing in each historical era. In its western context, the concept has evolved and grown. Throughout the span of time in the west, the powerful and the ordinary have known the concept in differing ways, sometimes distant and abstract, other times near and concrete, that is, a state of affairs almost within grasp. During the times when the culture has mired itself in war, there have been many effects a peace hopes to repair. However, there was always one great effect of war. It allowed the victors to consolidate their power over a greater geographical area than they controlled before. Once those in power had secured their hold over any land and population, they were able to define the concept of peace themselves, and their definition favored their desires. Yet, the victors had their struggles, which related to the power they wielded and how they planned to keep it. However, as the concept of peace developed and the articulation of the will of the populace grew, struggles developed between those who wished to maintain power and those who wished to express a new will and thought. For example, in the Westphalia period, the peace treaty assessed no blame for the war on specific nations. The Treaty was a perplexing document, having borne the brunt of praise and criticism depending on national viewpoints (Parker 215-217). This fact signaled an openness to new ideas of governance that mostly arose from the writers among the populace.

Throughout western culture, four different uses of the concept of peace have manifested themselves in the relationships existing between power brokers and the people under their rule. These four uses allow for tracking the development of the concept of peace itself from its beginnings in imperial Rome through early-Renaissance 
Siena, the Westphalia period, and the first hall of the $20^{\text {th }}$ century. The concept of peace has been used

1. To dictate behavior of the populace (Rome)

2. To legitimize the power brokers (Siena)

3. To formulate a new balance between states/nations and populations (Westphalia)

4. To achieve an end to unbridled hostilities that cause wars leading to the establishment of a forum for world order $\left(20^{\text {th }}\right.$ century $)$

The first two uses were determined by the power brokers. The final two expressed the strengthening voice of the populace.

Gerardo Zampaglione in his study of peace in antiquity noted three concerns that mark the arrival of the concept of peace: a) "the idea of external relations based on the great power achieved" by the empire; b) "the liberation of the body politic from the shadow of civil war," essentially a recurring European situation and, c) "the idea of the formation of an atmosphere favorable to the activities of the mind" (135). These qualities aid in a comprehension of the underlying significance of the concept of peace in the development of western culture. Depending on the purpose of one's inquiry, the concept of peace parallels the development of the western mind as indicated in the histories and sciences as well as the western emotional knowledge seen in the arts and literature. Additionally the development of the concept of peace records the fact of the populace assuming its role in establishing peace.

It is a mistake to assume that the concept, at least, has been around "forever" in one guise and that the concept's existence conveys a natural part of human nature. As western culture has continually endured the waging of wars among its own peoples, states, and nations, there have been doubts about the west's awareness of peace in any form other than an Ideal. The concept of peace differs significantly when one compares 
an understanding of peace in the modern age to the culture's understanding of the concept in antiquity. The Roman peace was a residual effect of the civil war that had impinged itself on Rome. The power brokers motivated by self-interests were generally concerned with the quality of life in Rome rather than in the outlying conquered territories. Roman power brokers controlled those territories that brought revenue and goods into a city that knew an organized civic life. In this period the emperors had solved the problem of civil wars, which had distracted the patrician Roman citizen from his life of virtus.

Generally for the west the meanings of peace applied differently to the culture across differing cultural periods. The concept that evolved across the centuries did not really take hold until the Modern eras. It was an ideal embraced by the populace that also evolved based on needs of the time. Previous to the Modern eras, the power brokers took the responsibility to disseminate the uses of the concept of peace itself and used the idea for their own purposes. In some cases, they ultimately employed the idea of peace as a positive advertisement for their effectiveness as governing bodies to ensure their stay in power. Ostensibly such power brokers did provide peace for the populace. While there is no expressly stated definition of peace or statement of change at any point in the historical record of the west, one is able to discern the change in the culture from period to period and the development of the concept of peace through its manifestations in political, artistic, and literary evidence. Politics and public policy, as still is common today, mixed the messages within the culture, because those in power had their images at stake, being concerned mainly with their own hold on power. Therefore, complete truth failed to emerge in political arenas until much time passed, and then frequently appeared as a filtered message. Often artistic evidence revealed the undercurrents of thought and 
emotion as well as the reception of policy within a culture. While the artistic evidence also implied a filtered message, the message from the art spoke for a different segment of the population, usually those outside of power. Even when those voices were approved by the power brokers, the thoughts and impressions of those outside the power structure had an outlet.

At the very least, the thinking of the people in the culture developed and remained sharp and, as happened in the $20^{\text {th }}$ century, forceful in its ultimate drive to be heard. However, in earlier cultural periods the voice of the people did not extend as deeply into cultural significance as does the voice today. However, that voice did evolve steadily into one of strength over the centuries. For example, by the early Modern era, the art of Rubens, long before the end of the Thirty Years' War, began to herald an indication of the true effect of long-lasting war on the populace. In his painting, The Horrors of War, Rubens showed how the personification of War tramples the arts and sciences of European civilization, which he represented as a wailing woman (Magurn 409). In the $20^{\text {th }}$ century the artistic evidence of Picasso depicted the deep and familiar horror of an event such as the bombing of the Spanish town, Guernica, during the Spanish Civil War and Jater for the first time in the aftermath of the world wars depicted the scope across western history of both war and peace. In Picasso's painting, Guernica, the residents of the town had been bombed, and they were depicted as wailing women in the painting, actively holding their lifeless ones, their resistance symbolized in light. In the early 1950s, Picasso situated his commissioned War and Peace murals in a chapel for continual reflection and meditation. "He wanted to work in the secular spirit of a "temple of peace"" (Leal, et al. 390). The chapel housing the murals was built to provide an "atmosphere 
favorable to activities of the mind" (Zampaglione 135), that is, a room for contemplation. Time set aside for such imagination oscillates between a real and supposed time, the abeyance of time also having an effect on the mind. Characteristic of the Modern era was the ability to use such artistic knowledge, technique, and realization to depict cultural attitudes in advance of the effect of events that weighed on the populace. In fact, the work of Modern-era artists often suggested the way events would appear to future populations.

Literary evidence further expanded the culture's awareness of the concept of peace as an indicator of the development of the culture as well as the way the rulers' use of the concept of peace affected the citizens they ruled. In the Sienese period, Dante essentially exiled himself to write his cosmogony of the world and the culture as he understood it. In the early Modern era, treatise writers evinced the intellectual efforts in the new Europe to circumscribe places for themselves in the new social order. By the time of the $20^{\text {th }}$ century, T. S. Eliot, writing in highly artful language, was generally able to express the disillusionment and fear of being mired irrevocably in perpetual war as it reflected the history of recurring warfare throughout the west. His most significant expression of this disillusionment and fear appeared over a 20 -year period beginning in "The Waste Land" and continuing in "Burnt Norton" and the other Four Quartets.

After tracking the developing aspects of the culture as evidenced in art and literature, one may openly search within the culture for the imprint of the popular will that determines the development of the concept of peace. The visual and literary arts of the west expressed essential elements of the popular will throughout the history of western culture. The artists in contrast to the power brokers were the ones who displayed 
allegiances to the culture that the power brokers could not feel because of the level of their self-interest in the perpetuation of their own power. Those in power wanted to stay in power. Depending on the stage of development of the culture and the strength of the development of the concept of peace, which was stronger in periods when the popular will was strong, those in power would not have to exercise much effort to stay in power. As the centuries passed and the populace gained a stronger voice in the workings of public order, the development of the concept of peace fell under the purview of the popular will and the power brokers must have struggled harder to co-opt the concept of peace to serve their own purposes or acknowledge the will of the people in regards to the developing concept. The formal structure of art and literature helps articulate the thought of periods of time in the development of the west. The fact that the arts so publicly express the culture testifies to Gerardo Zampaglione's favorable atmosphere for the life of the mind. Since Rome provides a fully realized starting point for the concepts of western culture, an idea of viewing-important figuratively and literally in the Roman cultural framework and by extension throughout the developing culture-is an essential element in establishing the artistic and literary evidence for this study. In western culture viewing - the way one regards what one sees, the context in which one regards something - is crucial to assessing the impact of individual cultural expressions. One may develop a viewpoint on the concept of peace in the west by tracking the artistic and literary expressions of different historical periods from the Roman empire through 1952. The practice of viewing allows for a discussion of each isolated period's relationship to the development of the concept of peace and of the ways in which the periods build on 
each other. Understanding the concept of peace depends initially on an understanding of the way in which Romans viewed their cultural affectations.

Viewing was an important aspect of the way in which the Roman citizens understood themselves. Within a socio-political context, the viewing of paintings and experience of literature provided the culture with views of the mindscape of the citizenry that lived in a particular context. For example, Jas Elsner in her study, Art and the Roman Viewer, focused on the significance of viewing for Romans. "The ways Romans looked at the world were in some sense conditioned by the ways they looked at art and vice versa" (5). In the Modern eras, these views sometimes prescribed a popular sentiment before it even reached the general public. For someone living in the $21^{\text {st }}$ century and accustomed to the relativity of ideas and frames of mind, Elsner was suggesting the subjective and objective views of the world blended. This scrutiny of one aspect of the Roman eye explained the way the Romans could split their focus between the conceptual empire and its state of affairs and the actual effect of their rule over the imperial holdings beyond the city of Rome itself. There was a "change between Classical art, with its emphasis on likeness to the natural world, and the abstraction of late-antique art." It came from the period of Augustus and lasted through "the first full flowering of Christian art under Justinian, [who ruled from 527-565 c.e]" (5). Elsner did not see the changes as obvious, because she questioned style as the main criterion for judging art. She did not want to focus on formalism, but on the weight given the "functions and meaning of art in Roman culture" (6). Art functioned within the culture as an aspect of every other facet of the culture, not separately from them. As such the development of the concept of peace as it manifested and exemplified itself through the public arts reflected the evolution of the 
concept more revealingly than if it were expressed in a treatise. The way in which the various traces of cultural life interrelate were often too complex to emerge only through the language arts.

In the early periods of western culture, art expressed what its patrons, those with power and funds, wanted it to express as in Rome and Siena. By the Modern eras, beginning with the Westphalia period, art had gained the ability to presage certain undercurrents of cultural energy as they formulated themselves in public spaces. The result depicted the manners in which the voice of the populace grew and had an effect on the will of the power brokers, such that public artistic expression was no longer exclusively a direct result of patronage to the extent that it had been in the past. As a result, the lesson that art functioned as an entry point into the drives of the entire culture developed the undercurrents all levels of western societies felt the effects of and fed on. Articulating the development of the concept of peace through the centuries presented a growing definition of peace that revealed another aspect of the depth of humanity among the western populations.

Elsner noted that the ways of viewing one could detect from Roman times revealed the different subjective responses in that period and through the culture to the contemporary era (5). When one got closer to the depths of Roman thought, one began to sense the "deeper inclinations" at work in the cultural mindset. Scholars could follow the thread of many facets of mental activity and cultural sensibility, including the weaving of the fabric of the concept of peace. Two of the most visible manifestations of the concept of peace in the Roman Empire had been the Forum of Augustus and Vespasian's companion piece to that Forum, his Templum Pacis, "inaugurated" in 75 c.e. (Noreña 
31). These two public monuments established visible acknowledgments of peace in the empire as well as being testaments to the efforts of the two emperors who had constructed them. Those architectural expressions bore broad cultural meaning, which were taken over by the art of painting in early-Renaissance Siena. In a conclusion similar to one of Arnold Hauser's, Elsner wrote that "the meanings viewers located in images depended on the kind of 'reality' they ultimately wanted those images to represent" (48). Cultural periods received the expressions of what their artists were capable of expressing, because of the thought available to them. For example, Elsner noticed "monuments, houses, and works of art help to construct a collective sense of subjectivity within culture...however, monuments may work not only on the collective level by propagating generally accepted sensibilities. They may also work on the individual level, helping an individual to construct a private and more person[al] sense of self" within his own culture (Elsner 125). Artworks "embody the authority of a cultural canon" (126). "Identity transcends place... deeply implicated in this nostalgic sense of identity is the repeated theme of autochthony-of peoples being born from the soil they inhabit" (140). The arts and literature of a culture reflect the knowledge and sensibilities gained from such a genesis.

The notion of Roman viewing provided a guiding principle to the comprehension of the development of the concept of peace in western culture. The practice of viewing opened a world. Jas Elsner wrote

The history of viewing becomes in principle a history of how people interpret anything in their world-nature, art, other people. Greek and Roman intellectuals were more self-conscious about how they interpreted and viewed their art than they were about how they interpreted and viewed other material objects in the culture. ... the importance in the viewing of art is that it was a secondary process. Looking at an image, a beholder is assessing a view of the world already created 
by an artist. In the viewing of art, the artist's own creative viewing of objects is a critical mediator between the beholder and the world (4-5).

The Roman idea of the known world, that is, their world, encompassed within the empire all aspects of their physical and mental world. The Greeks, of course, had preceded the Romans in establishing many intellectual concepts, but the Romans received those concepts, adopting much from the Greeks and every civilization the Romans encountered on their way to building their empire. Then the Romans fertilized their appropriations with the loam of organization and order. The result in the long view was felt throughout the Modern eras and beyond. Certainly early-Renaissance Siena established its own greatest achievements in the spirit of such an order as Rome exemplified. The development of the concept of peace became more tangible as history moved on from the Roman era.

In the first half of the $20^{\text {th }}$ century T. S. Eliot thought tangibly in terms of the elemental (and intellectual) soil from which humanity springs. Earlier in the same period Heinrich Wölfflin thought in terms of the juxtaposition of two particular artistic styles from neighboring historical periods that one may apply to different cultural eras to elucidate a particular method of viewing the culture as styles always function contemporary to a particular time. One gravitates to an idea of what is visible to a culture through its art and literature. The viewpoint that Wölfflin promoted drew a distinction between classic and baroque depictions of scenes in paintings as distinctions in artistic time in which new artistic ideas were created. These ideas expressed cultural viewpoints that exposed the will of the populace more than of the socio-politically powerful. In classic $15^{\text {th }}$-century paintings, for example, highly outlined depictions of scenes and 
figures guided the eye along the lines of the tangible aspects of objects. For that era the socio-political world organized its reality in hierarchical ways. One may recognize this type of depiction in the work of the Sienese painter, Ambrogio Lorenzetti. By the $16^{\text {th }}$ century, the west was viewing a deeper space in its paintings suggesting there was a limitless quality developing in the century's understanding of the world. This baroque world for Wölfflin was "a shifting semblance," which offered depths the previous century had not perceived or did not represent itself as perceiving. In short, the elements of a painting, for example, in the earlier century stood out as parts of a whole. By the $16^{\text {th }}$ century, the parts were understood more as aspects of a theme (Wölfflin 15). The $16^{\text {th }}$ century baroque style amplified what had been offered in the $15^{\text {th }}$-century classical style adding a deeper range of perception of all aspects of the culture. By extension of the idea, such differences were viewable within the historical periods. One may view each of the historical periods as embodiments of both the closed (outlined depictions) and open (deeper spaces) forms of which Wölfflin wrote. On the one hand, the artwork developing from one period to another may appear more closed or open in relation to the limitations the artists of each period imposed on it. On the other hand, the juxtaposition of the sociopolitical framework of an historical period and its artistic expressions may have exemplified the same type of juxtaposition in ideational form for an historical weltanschauung such as Wölfflin attributed to artistic works.

Humans see what their historical periods allowed them to see. Wölfflin wrote "different times give birth to different art" (9). If literature and painting are to be useful as lenses through which historians may view certain eras, one may apply to each period the distinctions Wölfflin established. Each period displayed the appearance of the way in 
which it understood its own reality and its own relationship to the concept of peace. In the same way the concept of peace developed, more or less holistically, with every other aspect of the culture specific to each period. The concept of peace as an ideal seemed particularly western in its construct and in the fact of its necessity. In the Modern eras, society comprehended the awfulness of the European wars. Europe needed to learn how to civilize itself peacefully. The Ur-past, the sanctified past rose up to impress the populace at different levels in the culture's development across time. Especially in Siena, whose leaders felt deep bonds to the Roman governance of antiquity and to ideals as well as their own sense of native place, the power brokers were able to detect an adoption of the concept of peace as a collective goal to attain. Peace evolved in the shadow of war, almost regarded as a toy of the power brokers and the patrons of culture until the Modern eras when the wars became horrors of human existence and the group truly affected, the populace, began to voice its will urgently instilling a new force into the development of the concept of peace.

Society and the individual---the artist, the writer-"become representatives of a dynamic" at work in a social order through which historians posited and understood the reasons for human development—on any level—in a particular time. Both Arnold Hauser and Heinrich Wölfflin discussed theses of viewing and perception born of the logic of history. For works of art discussed within art-historical significances, it did not matter who produced the work of art. Hauser explained the workings of minds in specific generations and how that structuring brought out the expression of a particular world view. "Only when we become aware of the fact that not only every culture is the work of several generations linked together, but also that the individual age-groups cooperate and 
compete at the same time in the process can we grasp the dialectical nature of the process which is taking place" (Hauser 131). Hauser, noticing a distinction about art brought to the fore by Wölfflin in the early $20^{\text {th }}$ century, recognized a quality in the production of art the French might describe as a devoir, which the English language can only weakly approximate as a "must-do effort." The notion of "artistic form," Hauser read in Wölfflin, “is not created freely or spontaneously, but neither is it conditioned by economic or societal externals. It is prescribed by the logic of history and accords with a possibility the artist and his generation can and must realize" (86).

They, artist and generation, could act in no other way but with historic logic, produce no other object, except that which the culture needed to be expressed at the time of expression and that which the culture was capable of viewing. For this reason, one could trace the development of the concept of peace through artworks. Hauser comprehended from Wölfflin's regard of stylistic forms the conclusion that an individual artist is "a mere substratum of superindividual tendencies toward development" (86). Artists found themselves caught energistically in the flow of their contemporary thought. As such, it was easy for Hauser to understand that artists were the natural ones, the ones born to their interest, their craft, while scholars, connoisseurs, aficionados-those who studied at a remove from contemporary societal drives-were created by education (441).

The development of the concept of peace offered an insight into the emotional and spiritual development of the populations of the west. The power brokers focused on how the society would continue politically under their leadership. From artistic creations one could track culturally the movements of socio-political thought as they affected the populace and were registered by them spiritually and emotionally. In the early days of the 
culture, the artists expressed the will of the organized city-state mentality and point of view. As the culture developed, so did the artists until the Modern eras when many shifts occurred, one of which was the artists' capacity to speak for the culture before the culture found a method of vocalizing the expression. This discovery exemplified itself especially in Rubens' Horrors of War 1638 when the voice of the populace began to emerge in a lasting way, characteristic of the Modern eras, expressed by Arnold Hauser.

One thing is certain: every work of art shows clear traces of its own time, and contains the unique, unrepeatable, and unmistakable character of a historical constellation. It represents a stage in the development of style which is precisely definable, in technical accomplishments and in sensual-intellectual sensibility. It depicts people and relationships in situations which arise once and only once and addresses itself to individuals who judge the depictions from a specific historical standpoint and a particular social position (77).

The concatenation of such individual periods provided the historical linkages that marked the development of the concept of peace in the west through the artistic and literary evidence of historical periods. 


\section{CHAPTER II}

\section{ROME: PRELUDE TO SIENA}

The concept of peace as an ideal in western culture served an imperial purpose. During the imperial era, the concept of peace as Pax Romana represented control over the immediate countryside and peoples surrounding Rome, so cultural life could continue with ease and conquests could resume with focus. When the civil wars near Rome ended, the direct symbol of the Roman peace, the doors to the Temple of Janus, were ceremoniously closed by Augustus to signify peace in the empire. By closing the temple of Janus, at least, Augustus represented "peace, order, and efficient administration" (Zampaglione 231). The type of peace established by Augustus in imperial Rome, was a peace in name only, a peace within the city itself for the patrician classes, allowing laws to govern in a civil environment while enforcing the Roman hegemony beyond the city. The Pax Romana ensured that a show of administrative strength and organization extended and dispersed itself throughout the empire. Roman law became the law of all conquered lands and the idea of organization spread at the hands of the local administrators who by degrees were able to impose Roman culture on outlying territories. "None took the trouble to question the subject peoples, of whose view little is now known, merely because...nobody thought them worth writing down" (Zampaglione 135).

The development of the concept of peace in the west began in Rome through the agency of the Pax Romana, established as an all-important socio-political reference point. 
The emperor Augustus wanted to dictate a belief, that the absence of war promoted the quelling of aggression in the city. At the time, the Roman "attitudes centered around the Romans' proud conviction that they had been vested with the mission of imposing their laws and way of life on the rest of the world" (Zampaglione 137). When one considers that the Pax Romana was an institutional concept, one may comprehend how rooted it became in the imperial psyche. It continued further into the history of western culture, for example, into the early-Renaissance, Tuscan commune of Siena. The Pax Romana employed the term "peace" to refer to the tranquil and controlled socio-political life within the city of Rome. The outlying territories of the empire did not benefit from the Pax, except in gradually improving administration. There did develop "a single law" and "a single religion" (Zampaglione 137). In those territories, though, the end to war and strife had not come fully. Zampaglione suggested only the end to civil wars, which affected the city of Rome, counted as the proof of peace (136-137). As far as the activities of the mind that thrived during the Pax, the arts were represented by the public use of architectural spaces within the walls of Rome, such as, the Forum of Augustus and later the adjacent Templum Pacis of Vespasian, expressing the public policy toward the Pax of the emperor and his power brokers, the privileged class. The Aeneid, representing literature and poetry, introduced to the western imagination the narrative conceits of wandering, struggle, and triumph-at-a-cost. The viewpoint of poetry and literature in Rome during the Pax sees Virgil expressing the human soul in relation to place. In Rome, the roots of the culture had established themselves. Virgil's wandering Aeneas, who lands in Latium, roots western culture to a specific place. His struggles centered around the human notions of fate, duty, and love, but in his era remain more earthbound and 
exemplary of the physicality of his life's purpose, the founding of Rome. The spiritual threads of development that tied Rome to the future of the west developed through political, artistic, and literary expressions through succeeding historical eras. And, the development of the concept of peace depended on shifts in the world view from one era to another.

Each period in western culture expressed a viewpoint on peace. Sometimes the viewpoint was definitive suggesting the period was a watershed in the development of the concept of peace. In imperial Rome during the Pax Romana, there was evidence of the limitation of the Pax. Tacitus addressed the issue of Roman conquest as felt in the "remoteness and obscurity" of Britain: "To plunder, butcher, steal, these things they misname empire: they make a desolation and call it peace" (Tacitus 81). Tacitus's viewpoint revealed the limited reach of the concept of peace with imperial Rome. More accurately, peace for the Romans meant control over the immediate countryside and peoples surrounding Rome, so that cultural life could continue with ease in Rome and conquests could resume with focus beyond the walls of Rome. When the civil wars at home ended, Augustus ceremoniously closed the doors to the Temple of Janus, the direct symbol of the Roman peace. However, wars continued when necessary to maintain the empire's sway outside Rome (Zampaglione 137). Meanwhile, cultural, political, and family life continued unabated within Rome itself. The Pax Romana was the west's most significant and idealistic representation of peace to this point. The empire's use of the Pax Romana provided the foundational meaning from which to spin the development of the concept of peace in the west. 
In the west, the Pax Romana first brought a meaning to the term peace even though it contained first-use contradictions and limitations. Basically the Pax referred to the peace inside the walls of Rome for the ruling class of citizens, the patricians. Simultaneously war had continued under various guises beyond the gates of Rome. During the reigns of many of the emperors, life in Rome was contained and orderly. The message of a successful peace excluded a great deal of the citizenry of Rome itself.

After the Roman era, the concept of peace bore a legacy in the west and served a different function in three succeeding historical periods. In Siena, the concept served to help legitimize the rule of the power brokers in a society increasingly under siege within its region. Allegiances were shifting and mercenary raids had begun in the region (Caferro 19). In the Modern eras, peace became arduous work by the early Modern era around the time of the Treaty of Westphalia. By the $20^{\text {th }}$ century, the work to achieve peace in a concrete way became laborious, constant, and contemporaneous with the prosecution of war.

In the west, as the concept of peace developed and the articulation of the will of the populace grew, a struggle developed, too, between those who wished to maintain power and those who wished to express new will and thought. In Rome, though, the power brokers did not find the maintenance of their power to be difficult. The monuments to the effective rule of Augustus were situated among the Roman Fora. Donald Dudley wrote that the Forum of Augustus was designated by Augustus as a meeting place, an architectural creation containing statues of great Romans of the past 
whose presence he employed in tribute to underscore the significance that his own achievements as emperor were of equal distinction to their collective ones (Dudley 129).

If one may not want to ascribe completely to the Romans the idea that they alone created the concept of peace, one may suggest they consolidated the concept for the west. Augustus understood the consequences of peace. The security of peace was based on a centralized governmental system, which exerted authority over liberty. Later the Nine in Siena centralized their system, but without the same degree of authority over liberty. Gerardo Zampaglione discusses the Roman authority in The Idea of Peace in Antiquity. "In the celebration of the order and stability assured by the empire, there was a sense of legitimate satisfaction for the tranquility achieved, from which every citizen benefited" (134-135). These citizens dwelled within the city. The Pax Romana was based on and succeeded due to an exercise of imperial power. Whenever there was a cessation of hostilities, the act occurred on Rome's terms. For example, when Rome fought and conquered other lands and other peoples, treaties between Rome and the conquered governments defined one state of affairs only, the "unconditional surrender of a defeated state" (133). This modus operandi maintained order in the conquered areas, keeping peace by understanding positions within the Roman hierarchy. Behind the Roman Pax was a logic of history that relied upon the subjugation of conquered peoples and governments, which liberated the Roman population from the shadow of civil wars. Of course, the ruling classes benefited from the spoils of wars, which defined the benefits of peace. The further removed Roman subjects were from the central city, the less status they had politically and socially. 
In any historical period artistic expressions record the needs of the present. In Rome especially, the production of art became a tool for the power brokers to use in correspondence with the socio-political methods they used to complete their hold on power. Useful artistic creations that conveyed the expression of peace in imperial Rome included the Forum of Augustus, which defined a meeting space for those with social and political status. While meeting they could contemplate the meanings of the lives of the past citizens and dignitaries whose lives served as models of the Roman character and whose ambition generally was deemed virtuous for the empire and that the emperor could use to sanction official acts. The concept of peace at this stage in the development of the culture was congratulatory and served a self-aggrandizing function for the members of the socio-political elite. One effect of this self-serving character of rule is that when governments did not allow some incorporation of the will of the people in their structures, the governments tended to stagnate, a condition that recurred throughout the history of the west. Mason Hammond discussing the Augustan Principate could have written about any western government throughout history when he deduced "the ultimate stagnation of the Roman state must be traced in part to the growth of a governmental caste which was more concerned with the preservation of the administrative machine on which its own existence depended than with the real needs of the people" (193). The Roman model of government was complex, influential, and lasting.

Augustus died in 14 c.e. A succession of emperors followed in his wake and their focus of attention grew more inward until Vespasian emerged from the ranks of the military. As the first emperor unrelated by blood to Julius Caesar, Vespasian in his short reign made the effort to return the focus of imperial duties to the example set by 
Augustus (Noreña 29). Vespasian's efforts brought attention to the concept of peace back into the public arena by creating a monument in the Roman Forum to the concept of peace, his Templum Pacis. Where Augustus had established the legitimacy of his rule and his idea of empire by rooting his sense of heritage in the achievements of past Roman citizens, Vespasian grounded his rule in the example of the Augustan principate itself. A.

J. Boyle details Vespasian's contribution.

In his Temple of Peace, completed in 75 c.e., Vespasian not only provided a public art gallery to invert and replace the private collection of the Domus Aurea, but created a building which enshrined the central theme of Augustus' principate, and which combined in one complex the literary function of Augustus' Temple of Apollo (two of the halls that flanked the Templum Pacis were libraries) and the military triumphalism of the Temple of Mars Ultor (hence the dedication of prime spoils from Jerusalem in Vespasian's temple) (5).

"Claudius, too, was an important model for Vespasian, who had received military advancement"... who had "completed the Temple of Divus Claudius begun by Agrippina and restored his cult" (6)

The Pax, though, did not mean that Roman conquests were merely past events.

"Claudian precedent also lay behind Vespasian's continuation of the conquest of Britain"

(6). Vespasian grounded his and Rome's authority in the continuation of past rules. He did not camouflage his background as a military commander. The divine ordination of his rule was suggested, however, as Boyle indicated by "the reappearance of Fortuna Redux" on Roman coinage in Vespasian's reign (7). Such an artistic rendering of Fortuna under his auspices indicates how successfully the emperors were able to communicate their values and pride of rule to their subordinates, such as, the Senators among the greater flank of power brokers.

Vespasian also raised taxes to offset earlier indulgences of the emperors and the losses of the civil wars that recurred before his reign (7). Yet he possessed the ambition 
to reestablish the quality of the Pax and regain it conceptually. He put the development of the concept of peace back on track. (A comparison is apt between Vespasian's Templum Pacis as prelude to a public-arts project initiated in early-Renaissance Siena by the Nine who ruled there.) As with many public-arts and architecture projects in the Roman Fora, the Templum Pacis was a place where the patricians gathered - this carried over to some extent in Siena, except that the public buildings hosted official business-which included the merchant and middle-class: "What resulted from Vespasian's policies was not only a public-works program to rival that of Augustus but the financial reinvigoration of the empire itself" (8). "Financial security meant political security," which for Vespasian "meant dynasty" (9). A dynasty in control meant a orderly government, which could maintain the Pax.

Vespasian brought a new quality to rule in Rome. Power itself was the new aristocratic sense. This was not power based on family connections, but after "the cataclysm of 69 c.e.," Vespasian leaned toward his "military supporters in the east," meritorious members of the senate class, and other such examples of men who showed leadership qualities (Boyle 10). Ronald Mellor explains that "Vespasian became emperor of the entire empire rather than merely of the senate, the Roman plebs, and the army" (82). The Flavians, the dynasty to which Vespasian belonged, represented their power on coinage as absolute (Boyle 15). By doing so, they began to repair damage done to the Roman soul by the emperors who preceded Vespasian, especially emperors, such as, Nero.

With Vespasian, his military background showed forth in the amount of control he exerted over the city including its citizens. One artistic discipline through which that 
control manifested itself was architecture. There was a difference between Augustan and

Flavian architecture. The former, Boyle wrote, "controlled urban meaning through

spectacle and display. What was at issue [in the latter] was the control of urban space and the bodies within it" (32). Surveillance is overt with the Flavians where it had been covert with Augustus (33). How they wanted to promote their image can be seen in the

hallowed Roman places [that] were appropriated to promote legitimizing Flavian values: the restitution of social order and the establishment of the Flavian peace (echoes here of the paradigmatic Pax Augusta); Flavian pietas, beneficentia, prudentia, imperial power, splendor, wisdom, triumph, divinity: the basis of the Flavian right to rule-political, social, military, and divine (30-31).

"Domitian's 'connections with the gods"” (31) also caught sway. The Flavians built forts and encampments everywhere. (Later by aspiration Siena compared to Rome. However, Siena simply covered less acreage.) The difference, though, between the first principate of Augustus where the

building program was its sense of culmination and closure: In the Augustan Forum and the [Augustan] Ara Pacis, as elsewhere, Roman history, religion and myth reached its divinely determined telos. Despite its allusion to the first principate, Flavian Rome seemed adjacent to that tradition: set apart, uprooted, arbitrary, multiplicatory, erasory, replaceable. [It was] invasive. The concept of peace survived in correspondence to the sense of order Vespasian brought back to civic life (32).

On record, the Flavian era became a period of peace. Yet, from the literature of the period we know that Flavian Rome directed the very period Tacitus recognized as "even in peace full of horrors" his assessment in his Histories 1.2.1. Suetonius, less harshly recorded in Vitae 1.1, regarded the Flavians as those who "finally upheld and stabilized the drifting empire." What the literature suggests here and throughout the development of western culture is that perhaps all the periods in the culture offered different nuanced versions of $d r i f t$ between wars. This view underscores a sense that the 
development of the concept of peace, which in the west, vacillated between success and failure.

William S. Anderson underscored the idea that the arts in Rome recorded the needs of the present. Writing about The Aeneid Anderson noticed the similarity of Aeneas himself to Augustus, which equated the fictional and actual worlds in a way Augustus approved. For example, in Book Ten, line 256, morning arrives. Aeneas stands "on the lofty stern of his craft." The image related to the "battle [depicted] on Aeneas's shield: like Augustus, he stands high on the poop; like Augustus, he has his head surrounded by light. Implicitly, then, Aeneas is about to face a battle which partakes of some of the symbolic qualities of Actium: he is the representation of Order, the hope of Peace, entering a scene (82) of Disorder and War" (81-82). Aeneas' actions and his entire story, at this period in the culture's development, circumscribed a sense of place in the culture. The Aeneid starts with a storm driving his fleet off course. One understands how the Romans viewed Aeneas, his ship, and his companions as a defining character in a defining situation that expressed the Roman location, its struggle for meaning, and its reason for existence. In this way by extension from the image of Aeneas, Augustus strengthened his principate, conquering and controlling the places he could in the way in which he could and still maintain control. Similarly Aeneas faced off against Turnus at the end of the poem, aggressively exacting control over Turnus for disrespecting his spoils of war, Pallas's sword. 
At this point in the history of the west, the culture essentially had begun to move as a dialectic moves. With the appearance of art and literature that fit official state needs, in a sense, the west had fully encountered its cultural perimeter. Arnold Hauser recognized this critical point in culture and history, which was similar to "one of the main problems in philosophy... [when one notices movement] from mere nature to culture and history" (331). The importance of this point was that the culture then moves more deeply beyond this beginning point but not always with a focus.

The doctrine of dialectic proceeds from the principle that it is antinomies in which attitudes which are becoming questionable and which are in need of change... assert themselves as laws and demands. Every one-sided point of view and aspect, every particular interest and striving for success brings about contradictions and presents the individual with alternatives which force him to make a choice. Every new perspective is linked with a contrary or divergent view which cannot be disregarded. The more numerous the points of view which come to light in this conflict of attitudes, the more favorable the prospect of determining the decisive motives of the finally established attitude from among the antithetical interests. The aim of dialectical thought is to achieve the most far-reaching approach to the totality of the forces in conflict with one another and to attain if possible an exhaustive picture of the sphere from which the constituents of the complex that is under discussion come (331).

Western culture from this point would move in divergent ways as would the concept of peace including the reason for the need for wars. However, they would not move in parallel. Both war and the concept of peace increased in intensity as they evolved and recurred from Rome to the $20^{\text {th }}$ century. In each western period and region, the mind of the time and place determined responses. Each period embraced a regional and temporal mind through which it apprehended its own culture on the cusp of change and development.

Roman culture established a trend in the west with the awareness that artworks, especially architecture, encompass, as later centuries would employ images in paintings 
and those in literature, aspects that reveal basic dimensions of significant cultural meaning. As the culture developed into the Modern eras, one could comprehend how these ties broke and shifted, opening up the culture to new meanings and uses, especially in artistic expressions that did not have to be affixed to a place as did architecture. Paintings in the Modern eras were no longer necessarily tied to the architecture in which they appeared or to a specific location which itself was part and parcel of the artwork. Together with the change in the world view across the centuries, communication of ideas increased. Fragmentation and standalone images became easy to duplicate in pieces and send into the culture. The ties to their Roman beginnings created a method for the culture's ability to view things as meaningful. For example, in Rome, even on the small architectural scale of the house, Jas Elsner observed "the operation of desire in the Roman house further [provides a] link between allusion and illusionism of Roman walls" (76). The important quality here was the view, which continued to influence future periods. For example, in Siena, "wall painting[s play] with the same issues as architecture" (76). Those paintings were frescoes that an artist painted onto the surface of the walls as the fresh surfaces dry. Painting and wall then became inseparable from each other. In the public building in which the Sienese frescoes appeared, they covered the walls in the rooms to such an extent that the frescoes brought indoors not just the painted outdoors scene, but in essence the entire countryside under rule by the very rulers whose characteristics as a communal ruling body were represented on the wall as well. The view tied to place then-in Rome, of the house, in Siena, of the public building-concerned the relationship between here and there for the viewer, the place where he stood and the direction of his viewing. In Rome this relationship determined "the visual and social 
articulation of the Roman house" (76). Pliny described his house from room to room with an emphasis on views. The "topographical sense of flow in architectural space" served as a mnemonic tool, for example, to help orators memorize their speeches. They could "view" the organizational elements of their speeches just as Augustus and Vespasian could view organizational effects on citizens in the Fora. The Roman culture placed a great value on rhetoric and its organizational qualities (Elsner 76). Quintilian himself described the use of a Roman house as an organizing tool for committing a Roman speech to memory (Institutio Oratorio 11.2.18-20). A first thought was placed in the vestibule, a second in the atrium, and so on.

If the Roman house, the layout of a dining-room, the common architectural forms of the late Republic and early Empire, served regularly as the means for ordering and memorizing speeches, then equally the order and structure of these very houses, dining-rooms and architectural forms are the three-dimensional embodiment of the process of structuring thought...the Roman house in the totality of its rooms and décor is one representation of the structure of Roman rhetoric...in effect, we cannot draw a sharp distinction between the architectural and visual world of the Roman educated elite on the one hand and their mental and rhetorical world on the other. Together they make up the mentalite, the particularity and identity of Roman civilization: Each was the precondition and determining impulse behind the other (77-78).

The flow (of place to place, of the structure of a speech, of thought, of propaganda, and so on) of mental peregrinations created as visual play the scope and capacity of the western mind. The development of the concept of peace seemed in its peregrinations to be emblematic, too, of such scope and capacity.

It was clear that the concept of peace held a symbolic place in the culture during the Augustan Age in Rome when the doors to the Temple of Janus were closed in 29 b.c.e. The closing had not happened since the beginning of the First Punic War (264-241 b.c.e.). At that time, the political stance was that "peace had been achieved through 
victories," when Rome was acquiring lands it could rule (Galinsky 294). But, the record available today does not include evidence of voices from other strata of society beyond those patricians in power.

Three historical periods after Rome marked the development of the concept of peace. Rome effectively introduced the concept with the Pax Romana where pax connoted peace, security, tranquility, and order solely within the city of Rome itself. The Roman patrician class simply declared a peace had arrived. The rulers had solved the problem of civil wars and brought an internal organization to the Roman city/state. The evidence from painting and poetry that emerged from each of the following historical periods indicated how burdensome was the conflict between government action and declarations of war and how difficult it was to solve nationalist problems and address the popular desire for peace. 


\section{CHAPTER III}

\section{SIENA}

The Tuscan commune, Siena, provided the first real instantiation of the development of the concept of peace in the west, which depended on a direct intellectual and artistic heritage from imperial Rome, but signified more than an absence of war. In both Siena and the region, tranquility emerged as an aspect of the developing concept of peace (Marsilius 3). The commune modeled itself on the example of Rome as a successfully governed socio-political entity, ruled by the Nine during the period 1271 1355. The Nine had brought the Roman model to bear even though the commune was a fraction of the size of Rome. They regarded the peace operating during their rule as their gift to the commune, a direct result of their governmental charge, "to bring the city, commune and people to 'true and right and loyal peace and unity'..." (Waley 47). By inference the Nine, while not the creators of the link to a Roman heritage, promoted their connection to Rome whenever they needed to shore up their legitimacy in the eyes of their populace. This promotion came later in their rule, showing up in depictions of themselves, for example, in Ambrogio Lorenzetti's Allegory of Good Government (Figure 1). The Sienese peace was not a period into which the rulers could relax. The peace they claimed to have ushered in was hard-won from a period of regional civil wars. The Nine had carefully maintained the peace, a direct outgrowth of the order they had established. 
In Siena, the success of the commune depended on how well the Nine, the power brokers could maintain the civic organization they controlled since 1271 . Even though Siena had become by 1300 a commercially successful commune in the Tuscan region, the Nine eventually needed to stabilize waning support for themselves within the structure of the commune, which included the ranks of the Noveschi, from whom the members of the Nine were elected. Regional wars had ended as the Nine assumed rule. They brought stability to the commune that had experienced regional wars. But, mercenary raids outside the commune in the contado, the land around the city, as well as tensions within the community caused the Nine to make use of common methods for selling an image of their success, providing obvious proof of their merits as rulers. Additionally the fact that peace had reigned since they had assumed rule was a factor in their favor. The strengthening of the concept of peace in the culture was at that time beginning to be seen as a direct effect of a number of socio-political factors that included the quality of the governing skills of the power brokers. The Nine specifically ensured their own continuation as the ruling group by emphasizing their contribution to the peace of the commune as a propaganda tool to their benefit.

As visible in the Ambrogio Lorenzetti frescoes, peace had become an important quality in Sienese life during the period between 1271 and 1355. On many levels the concept of peace related to business prosperity and the trappings of good civic and personal lives. The merchant guild "increased its power throughout the rule of the Nine" (Bowsky 223). The commune while ambitious enough to make much out of its heritage with Rome realized the struggle it had to make to maintain the connection. Rome had commanded an empire. Siena was a small city-state. Previously, in the mid-1200s, the 
region of Tuscany passed through a period of civil wars among its city-states. The chief rivals for power had been Florence and Siena. There were other rivals in the region, but as the wars wound down in the 1260 s, these two city-states were victorious over each other at different times. In 1271 when the wars ended, the region seemed finally to have left the middle ages behind. The commune of Siena benefited from the rule of the Nine, a stable governing group of rulers because they were chosen from among the Noveschi, the larger group of civic and business leaders. The Nine, themselves, guided the peacetime prosperity of the commune as well as guarded the security of the contado. The arts flourished in this period. Using the arts, the Nine successfully reflected the commune's heritage with the Roman empire and, by extension, their own link to that heritage as well.

The period of peace following the Tuscan civil wars allowed Siena to maintain a point of view that clearly affected its contribution to the development of the concept of peace. In terms of peace, the Nine defined the quality of life within the commune. Under their auspices an expression of purpose for their rule emerged, which follows. "Without fear every man shall walk freely and each working, shall sow while this commune shall keep...Securitas in power for she has removed all power from the wicked." Ambrogio Lorenzetti included the statement as part of his significant fresco, the Allegory of Good and Bad Government. He represented the figures Securitas and Pax, Security and Peace, in such as way to make it clear they were cognates of each other in the fresco and that they were figures that implied a future direction for the commune. Their presence established the first open evidence of the development of the concept of peace in the commune and, by extension, the culture. 
Security and peace arose from the removal of the power from whomever the power brokers deemed "wicked." In other words, in the lore or myth, the qualities of Securitas and Pax removed power from their enemies. There was nothing in Siena or Rome that was internal to the culture in the way governing bodies accessed the concept of peace. The Nine in the name of security and peace-qualities of good government that either coincided with their rule or came as a result of their rule - took what they needed and removed impediments to their rule. When their rule was clarified in their tranquility, there was Peace accompanied by her companion Security.

Much that was Roman figured into the Sienese outlook, stoicism included, which was apparently the only Greek ideal that really attracted the Roman mind. Stoicism "provided a rule of ethics under which relations between individuals were interpreted in terms of mutual understanding and tolerance and because it appeared to suggest, in the field of relations between states, a system which could be used to justify Roman expansion" (Zampaglione 138-139). In the Tuscan region after the wars, Siena, Florence, and Pisa to some extent settled into a period of tolerance and peace at first by virtue of the fact that there was no war. Even though their rivalries were slow to fade and the cultural memories even slower to grow, the peace that occupied the communal governments in the region fostered a growth in the economy - business and trade flourished through effective foreign policy—-the arts, and the social order (Bowsky 184). Siena was particularly organized in all these aspects of civic life.

Even the city architecture figured into the development of the concept of peace in Siena. "In some ways the town of Siena itself was an artistic project" (Bowsky 295). The 
Palazzo Pubblico, the Sienese Palazzo Comunale, was the "object of continued attention, supervision, and support from The Nine" (285). The palace, having been built from 1297 to 1310 "for the honor of the Sienese commune and the beauty of the city," essentially represented the Nine in architectural form, not unlike the various Fora in Rome that represented various emperors. In 1315, Simone Martini painted his Maesta on the wall of a meeting hall in the Palazzo. The Maesta showed the Virgin, the symbol of the city, with the baby Jesus and the legend, "Love Justice you who judge the Earth.” This significant legend returned in the Lorenzetti frescoes. The Sienese artists conveyed "universal civic ideas" literally through many of their public paintings (Polzer 71). Some were sanctioned by the Nine, so may have reflected the viewpoint of the artists. In the Maesta, in addition to depictions of the shields of the commune,

the angelic flowers of roses and lilies with which the heavenly field is adorned do not delight me more than good counsel. But sometimes I see one who, for his own advantage, despises me and deceives my land. And the worse he speaks the more he is praised. Let each one watch for him whom this statement condemns. (Bowsky 286)

Furthermore the Virgin addressed the saints and concluded with the following statement. "But if the powerful molest the weak, your prayers are not for these, nor for anything that deceives my land." Such messages seemed to underscore a common attitude borne by the members of the commune. This civic ideal was aware of itself, aware of its own history. The concept of peace that came, however, did not erase the memory of what preceded it.

The civic focus on the town itself and its order contributed to the commune's organization and easily established peace with its neighbors. However, the commune eventually overreached itself in terms of finances and the scale of such projected building 
schemes as the expansion of the cathedral beyond the scope of what a commune the size of Siena needed. When the end came, William M. Bowsky suggests, it was the end of a dream. (285). The rulers had portrayed their civic ideals in the artistic "representations of the regime of the Nine" (284). For example, in 1308 a cathedral altarpiece "replaced the older portrait of the Madonna that was believed to have helped the Sienese at the battle of Montaperti a half century earlier." On 2 September 1260 "Siena dedicated herself to the Virgin, and two days later" won this battle (Schevill 275). Duccio di Buoninsegna, the Giotto of Siena, created the cathedral altarpiece and when finished there were festivities for three days to celebrate its completion. The inscription on the platform reads (284):

\section{Holy Mother of God}

Be the cause of peace for Siena

Grant life to Duccio

Because he painted you thus.

The "oath of office of the Nine specifically enjoined them to "provide that the commune and people of the magnificent city of Siena are and are preserved in good peace and concord" (Schevill 289). The concept of peace was threaded into the weave of the fabric of the Sienese soul, as if Siena were a laboratory for the maintenance of the concept of peace.

As successful as the Sienese commune was under the rule of the Nine, life was not easy. In the context of western culture in the period between imperial Rome, which provided Siena with its heritage, and the Modern eras to follow, Siena actualized its Roman heritage while other regional powers viewed Siena as a rival power that might develop weak points in its defense system. In Siena, a capacity to rule without distraction and with good results is what the Nine wanted. "They quickly developed a regime 
marked by a high degree of flexibility and innovativeness in response to changing political, economic, and, to a lesser extent, social conditions" (Bowsky 24). However strong the Nine's desire to emulate Rome, they did not succeed. Rome had been an empire. Siena never commanded such resources of citizens or territories. Neither did the other city/states in the region. Yet, they all wanted to maintain their control over their own rival territories.

In its way, though, Siena had achieved a sense of order similar to that found in the Pax Romana. The Pax had given meaning in the west to the term peace and the correspondence of order to the establishment of a life of virtue, as suggested by the three meanings. Siena, itself, ruled by the Nine, a stable governing force, was able to maintain that order based on similarities to the same three meanings that defined Rome: 1) "external relations based on the great power"; "liberation from the shadow of civil war"; and, "an atmosphere favorable to the activities of the mind" (Zampaglione 135). Once the Nine achieved the first two near the beginning of their rule, what remained to accomplish was the third. The artistic evidence in Siena during this time, much of it created under commission from the Nine, revealed the concept of peace growing. The concept had two functions: 1) The commune's values included their healthy regard for peace; 2) The Nine found a way to use the commissions to bolster their own legitimacy in rule. The concept of peace strengthened itself in this period in such a way that the citizens could appreciate its benefits, but also ensured the Nine could put the concept to their own uses.

The concept of peace, an ideal, had been sought throughout European history, beginning with its introduction and preliminary definition during the Roman empire. Depending on the historical period, the definition of peace referred to differing qualities 
of life, each succeeding period adding dimension to the concept of peace. However, war in the west had always seemed inevitable. The concept of peace allowed security, order, social development, equilibrium, tranquility, law, reason, but did not by necessity signify an absence of arms, hostilities, rivalries, in short, quests for power. S. C. Vestal surmised that "peace stays longest with those who are as careful to use their power justly as to show their determination not to submit to injustice" (551). In any era, the presence of peace allowed the culture to address the issues coincident with their time. The Nine perhaps exemplified Vestal's statement. Ultimately, their rule and the concept of peace stood as active partners for 85 years in historical relief to something more frequently occurring in history, which is strife and its attendant curses, distrust, fear, and evils. The concept of peace evolved during the Sienese period allowing the socio-political structure to thrive in the atmosphere favorable to its socio-political health. In this period of small civic focus near the heart of what had been imperial Rome, the commune of Siena made an effort to exacerbate its period of peace.

Throughout the west, governments of any historical period had their own power and special interests to protect. The desire influenced public policy in many historical periods. In later periods, popular will evolved strongly parallel to the government will. However, in Siena the popular will did not figure as strongly as did the perception of the tentativeness of the Nine's hold on order within the region. However, the popular will strengthened enough to cause the power brokers in Siena, the Nine, to govern well and promote the image that they were governing well. Protecting their image was the reason the concept of peace received as much official attention as it did. 
The concept of peace at this time began to signify more than an absence of debilitating war. Sienese citizens could develop business, family, and artistic lives. Yet, Siena simply did not have the Roman power to ensure peace over all of its local environment. As a result, the government and the populace worked together to maintain the stability of peace. Siena's peace, while a peace also within city walls, was one which the entire commune had to maintain and perpetually watch increasingly into the $1350 \mathrm{~s}$ after the Black Death, especially at the edges of the surrounding countryside-the contado. This collective effort enriched the use of the term "commune."

Even at this point in the west, the concept of peace in Siena shows a development with respect to things imperial Rome. The Nine characterized themselves as the inheritors of abilities akin to those of the Roman emperors, at least, in respect to Siena's smaller geographical scale. The Nine link the heritage of their city to Rome, and they do so by commissioning art to express such linkages. Originally the city had been established as a Roman outpost from the days of the republic's expansion. Theoretically the Nine governed as they imagined the Roman emperors governed, that is, efficiently and over all matters of civic life. However, not being as powerful as Rome and being competitive with other Tuscan city-states, peace for the Nine was not a state of affairs dependent on their own definitions of it. Instead, peace for the Nine was an achievement to claim and promote as its own.

Arnold Hauser explained the workings of minds in specific generations and how that structuring brought out the expression of a particular world view. "Only when we become aware of the fact that not only every culture is the work of several generations 
linked together, but also that the individual age-groups cooperate and compete at the same time in the process can we grasp the dialectical nature of the process which is taking place" (131). From the vantage point of a $21^{\text {st }}$-century observer, the arts of the Siena period opened the culture to continued viewing as a source for the development of the concept of peace. As Jas Elsner states in Art and the Roman Viewer, "the artist's own creative viewing of objects is a critical mediator between the beholder and the world" (5). Therefore, the dialectical nature Hauser referred to described the value of cultural mediation that an artist's viewpoint brought to the meaning of a period in culture.

In the Sienese period the arts set the stage for a stable discussion of the concept of peace. The Ambrogio Lorenzetti frescoes expressed the manner in which peace and war related to the type of government. The importance of the development of the concept of peace continues in Siena because the artists possessed the capacities to deepen their depictions of iconography with references to wider cultural knowledge and awarenesses while still enabling their art to remain pertinent to the uses of their patrons. The development of the concept of peace also showed abstractly, sometimes allegorically in the commune's cultural expressions, especially its artistic ones. Siena was important in respect to western culture. The commune produced many significant artists, one of which was Lorenzetti. His series of frescoes entitled Allegory of Good and Bad Government, appeared in the Palazzo Pubblico on the walls of the room of the Sala dei Nove, in which the Nine conducted daily business. Only the space in the room separated the depiction of the two aspects of government, good and bad, two aspects of one whole.

Parallel to the desire of the Nine to make the peaceful existence of the commune work for all its citizens was an intellectual and emotional desire for life to be unified for 
the sake of the communal mind. In addition to passages from the Defensor Pacis by Marsilius of Padua, a nearby city-state in the same region, one may infer in Dante as well that regional writers circumscribed the difficulties in the maintenance of order and the ability for the development of the concept of peace to occur in the region. At this point in western culture, the populace began to show its influence within the community. In the context of Sienese life, the Nine were by no means imperial in influence as had been the Roman emperors. Politically, the Nine were chosen from the Noveschi, a larger body of communal business and middle-class overseers. On the whole, the populace included the Noveschi, which meant that the term populace defined a different group than would be defined after the $17^{\text {th }}$ century. In Siena, this group held sway over the Nine.

In this period, then one would expect to see an expansion of the meaning of the concept of peace, which represented a stabilizing force for the idea of the government in power. The concept became an essential propaganda tool for the Nine to use on its own behalf to keep the minds of the populace off the occasional shakiness of the security of the commune, which was still affected moderately by rivalries with Florence, but also by mercenary raids around the edges of the contado (Caferro 44). Before this period, during the 1260s in Siena, the Ghibelline and Guelph factions had traded ascendancies (Schevill 189). For example, in the Purgatorio, Dante refers broadly to this period. "Thou inn of sorrow, ah, trampled Italy!/No Lady of domains, but brothel of shame!/Ship without pilot on a stormy sea!" (VI 77-80). Daniel Waley asserted the problem clearly. "[l]t was humiliating, after the 1260 s, to have to face existence as a junior partner of a once defeated foe," Siena's rival, Florence (Siena and the Sienese 126). Even though this 
period was peaceful in the region, the peace was partly defined in contrast to the memories of the civil wars. Memories were long in Tuscany. They made the most of the peace, because they remembered the alternative. There was one further complication for the landlocked Siena. The commune needed water. The Nine had to monitor the contado to maintain the flow of their resources. But, they were watching neighbors merely in their own region, neighbors they knew well, rather than being one nation monitoring a threat to its national boundaries as would happen later in the Modern eras in Europe.

Even though there were troubles with Florence, it was Dante's achievement in his Commedia that allowed contemporary readers to discern a vision of the unity of body, mind, and spirit-in correspondence to the three levels of empirical knowledge he passed through - that was achievable for him in this age. The early-Renaissance point of view differed greatly in mind from the Modern. Dante's allegorical investigation of the knowable world represented western culture's way of knowing the world during the early Renaissance. Paolo Milano, whose essay introduces the Laurence Binyon translation of the Commedia, agreed and in 1947 concluded that Dante's "peace of mind is our lost paradise" (Milano xxxix). During the period of greatest crisis in the $20^{\text {th }}$ century, Europe felt no such peace. Western culture throughout its history sought a union such as the one Dante expressed. At various points in the history of the west, the concept of peace for the socio-political realm had been available for development of the western regional mind. Dante's contribution to the direction of the concept was formative. He created a platform on which a cultural dialogue could take place. 
Perhaps the metaphor of Dante's journey to the experience of the worst possible level of existence, Hell, before ascending to the summit of earthly understanding was analogous to life during the late Trecento and early Quattrocento in Tuscany. Even Lorenzetti's frescoes, suggested that both good and bad government might exist simultaneously. Symbolically Dante represented such a simultaneous tension as a chasm similar to the River Acheron. At first, Charon did not want to take Dante across the river, because Dante"s soul was not really lost. He did not really belong there and was merely being guided through for his own edification. Along his journey to great depths before ascending the heights, Dante saw his Tuscan era in reference to that of his beloved Rome, the combination of both representing all knowledge to that point in the culture. Additionally Dante's vision pointed ahead in the culture. He was, in effect, the stand-in for his readers. For example, in the Paradiso, Justinian explained the history of Rome, the things he did wrong, and the ambition of the Guelph/Ghibelline desires to break current-day Italy in two. In the Paradiso, Dante's ancestor Cacciaguida spoke of the Florence of his day, "dwelling in peace, modest and temperate/She wore...no gaudy skirt, no broidered belt..." (XV, 99-101). Although the region was experiencing peacetime living at this point, Dante intuited the undercurrents of the type of struggle to which the Nine in Siena were attentive. This sense of unease equated to the awareness of difficulty the Nine felt during their rule as they worked to make the populace aware that the peaceful living they were experiencing was the result of the Nine's good government. The commune of Siena itself had to be a more egalitarian and consciously organized state than Rome had been, because the concept of peace was not dictated by unlimited imperial wills as it had been in Rome. 
In one final note applicable to Dante, Bernard Williams in Shame and Necessity, discussed the way in which divine agency in mythology operates, that is, through an agent's thoughts (22). Williams offers a psychological explanation for the monologues in Homer and Virgil. However, in Dante, there is dialogue, which allows for a difference from Roman literary examples. In the early Renaissance, the literary Dante and Virgil speak. Dante and Beatrice commune. There is a difference from Rome in the historical period. The era of Christianity instilled in the culture the sense that readers had a guide who preceded them, a guide whose task was to impart the concept of peace to human understanding.

During the Sienese period Dante provided the major literary voice expressive of the age. Dante's Commedia was the landmark western literary achievement of this period. The poem offered commentary on the Middle Ages itself, which elucidated discussions of the concept of peace. Dante's world view reached from his culture's past and suggested its future. In this era the concept of peace was easily understood simply as a state of affairs, civic development contrasted with war. The Sienese peace had been hardwon in contrast to the period of imperial Rome, when peace simply was declared by the emperor inside Rome disregarding what administrators from Rome spread among the territories. On most levels the Pax Romana represented territories conquered. In Siena the concept of peace represented a community organized and, in its way, nurtured.

On the surface, Dante also provided a link to Roman literature through Virgil, both the historical Virgil and Dante's characterization of Virgil as his guide. Dante's link to Roman literature made him a pivotal figure in an attempt to comprehend both periods, Sienese and Roman. Additionally his work with its roots in Roman literature pointed 
ahead to future poets, including T. S. Eliot in the $20^{\text {th }}$ century. Dante's conception of history did not equate with what specifically happened on earth, "but in constant connection with God's plan" (Auerbach 194). His work pointed to the future that was beyond the earthly realm. In that fundamental sense, Dante was imagining a way to peace. Of course, the statement referred to the spiritual peace of being subsumed into the heavenly body. A notion of spiritual peace, though, allowed for the striving of the human soul. Erich Auerbach wrote that the poem

is to be understood not only in the sense of human society as a whole approaching the end of the world and the advent of the millennium in a constant forward motion (with all history, then, directed horizontally, into the future); but also in the sense that every earthly event and every earthly phenomenon is at all timesindependently of all forward motion-directly connected with God's plan; so that a multiplicity of vertical links establish an immediate relation between every earthly phenomenon and the plan of salvation conceived by Providence. For all of creation is a constant reduplication and emanation of the active love of God, and this active love is timeless and affects all phenomena at all seasons (194).

The cosmogony of future periods was not so lofty. However, there was an earthly version of Providence that Dante had in mind as a model. According to Auerbach, the model was the Roman empire. "It is in Dante's view the concrete, earthly anticipation of the Kingdom of God" (195). Aeneas journeys to the underworld as a "special grace" due to Rome's fulfilled destiny to rule the world. "Christ appears when the time is fulfilled, that is, when the inhabited world rests in peace in Augustus' hands" (195). Therefore, the Roman empire was an earthly incarnation of the Kingdom of God, the locus of eternal peace. The Pax Romana therefore anticipated a Pax Caelum. Virgil had expressed the human soul in relation to this physical place, the Roman place, on earth. Dante took Virgil's expression one level further into the spiritual realm, adding the spiritual dimension to the concept of peace, transferring that dimension throughout the culture. 
One could understand the development of the concept of peace as a mark of the level of civilization the west was achieving.

In anticipation of future cultural life, Dante's characters in all three of the realms lived, Auerbach says, what Hegel would call, "lives of changeless existence" (191). These lives, however, still connected to their earthly ones through their memory and partook of the entirety of the realms through which the human spirit needed to pass in order to develop. Dante suggested movement through cultural knowledge which analogizes the movement through the culture of the concept of peace, which journeys through time in its development on behalf of the culture.

The organization of the communal life and the city arranged history. Throughout A Medieval Italian Commune, William Bowsky showed the Sienese commune measuring its success by keeping track of its revenues, sense of order, and planning. Dante organized his cosmos in the manner of his time, as well. The Commedia guided Dante through nine levels of Hell. His eventual goal is Paradise. Among other writers of the era, Marsilius of Padua, in his Defensor Pacis, organized the elements of life to produce tranquility, a key element for him in the development of the concept of peace. Stephen Toulmin in the $20^{\text {th }}$ century would suggest these writers were writing their cultural period to "some end quite other than the improvement of the medium itself" (Human Understanding 399). Their thought and language offered the culture a sense of order, which was desirable at this point in history. Order strengthened the concept of peace. Perhaps it was not yet organic to life but, at least, it was present even if imposed, directed, and overlaid. The following examples illustrate how three writers contributed to 
a sense of the maintenance of order that characterized this cultural period. This order assured the region of peace.

Dante (Florence)

Canto XI

Up on the topmost rim of a deep-cut bank

Formed by a circle of massive, fissured rock, We stood about a pen more cruel. The stink...

..."my son,

Within these rocks three lesser circles fall,

Each one below another, like those you have seen,

And all of them are packed with accursed souls;

In order that hereafter the sight alone

May be sufficient, you will hear what rules

Determine how and why they are constrained.

The end of every wickedness that feels

Heaven's hatred is injustice - and each end

Of this kind, whether by force or fraud, afflicts

Some other person....

This passage showed the descent to the Seventh Circle of Hell. Various kinds of guilt received punishment there. According to the Foreword to the Laurence Binyon translation of the Commedia, there were three kinds of violence in the Seventh Circle, with fraud in the Eighth. Canto XI showed order and its effect. The dominant theme was "not mercy but justice," ancient law was a retribution, which expressed a moral system of ancient philosophy (Freccero xi.).

Dante began the Commedia in a state of confusion, a state recognized as emblematic of the period. On a personal level and by extension representing a cultural one, Dante felt as aimless as his soul feels. He, of course, wrote in opposition to the Florentine government that soon put him in exile. His use of Pride in Canto II of the Inferno corresponded to the rise in pride of the Nine in Siena. Perhaps the metaphor of the journey to the experience of the worst possible example of living before ascending to the summit of earthly experience was the analogue of the experience of the Tuscan 
Trecento and Quattrocento. Plus, in spirit, Lorenzetti's frescoes later would suggest both good and bad government at the same time. In Dante the contemporary reader bore witness to the co-existence of inferno, purgatory, and paradise. For the west at the time, Dante redefined

the understanding of order. In his effort to preserve the common acknowledgment of man's uniqueness, of man's potential disharmony, and of the freedom of the imagination, Dante envisions order as dynamic and not static. The dynamics, represented in the guise of an ongoing unfolding of creation, recognizes the dialectical interaction between the exact boundaries and clarity of closed forms and the as yet incomplete role and perfectibility of finite man ready to transgress all bounds (Mazzotta 203-204).

Among the traits of the early-Renaissance human world, there was a perception of unity that slipped away as the Modern eras arrived. Perhaps the Treaty of Westphalia sought for the first time after the loss of unity to address a need and desire for it in the early Europe of new nation-states.

The concept of peace was not disseminated from as many sources as would happen in later cultural periods. In Siena the consciousness of the Nine recognized they had to begin to sell themselves as peace brokers as well. The poetry of the period revealed a differentiation between the Sienese period and the Roman one. In The Aeneid, Virgil had established a wandering hero, Aeneas, whose peace ought to have been found as a peace of place. Location was important to Aeneas. Rome should have stilled his longings. Yet, The Aeneid ended in conflict, aggression, which is symbolic of the contradiction between the Pax declared for the inner city of Rome while wars, skirmishes, and other conflicts continued to rage beyond its walls. Rome's epic poem, whose great subject announced from the first line the poem was concerned with war and one man, ended with that man, the founder of Rome dispatching the soul of his enemy "to 
the gloom below" (XII, 952). For the west, the nature of the cultural imperative had been set by Aeneas's final act of revenge for Turnus ostentatiously wearing the war booty of Pallas's strap. Enraged Aeneas kills Turnus for presuming to display his spoils. The poem ends and one must assume only that Aeneas and by extension the Roman race had found their true place as well as their true attitude, the attitude the west had to overcome, aggression. But that single quality determined the extent of the concept of peace for them. In Siena, Dante illuminated the concept of peace in its ability to grow beyond its Roman form. The culture of the west continued to root itself in the same geographical area in which it coalesced in its most expansive form, in Rome. The literary contribution to the concept of peace in the Sienese period appeared in the Commedia as a search for the peace of the human soul in relation to spirit, rather than only to place, which had been the emergent focus for Virgil.

Dante himself underscored this potentiality when he devoted Canto VI in each of the three poems to the subjects of Florence, Italy and imperial Rome respectively. In the prophecy offered by the poem, Florentine life did not pass in peace and order as Dante would have wished. In fact, he estimated only two men, whom he did not name, were just. He told in "The Inferno" that his city "which brims so/with envy the sack is ripe to spill" (VI 49-50) lived in the shadow of strife and soon "shall come to blood" (VI 65). Dante's words shaped an artful prophesy that came true within a half century or so either literally or figuratively. Either way the region was affected. Similarly the Nine in Siena may have felt the end of their reign coming as well. The region was restless with factionalism. Therefore, the commissioning of propaganda frescoes in Siena for the education of the populace did help the Nine maintain the order they claimed to have been 
instrumental in keeping to that point. Individual artists, such as, Dante, by virtue of his status as an exile, were beholden to neither Ghibbeline nor Guelph party and none of the other factions. As such, Dante's viewpoint was useful to the culture as an indicator of meaning for the regional direction of the development of the concept of peace in the culture. At this point in the culture, the concept possessed spiritual utility within a culture devoted to commercialisms.

In the Purgatorio, Dante lamented the state of Italy, which was either present-day to him, 1298, or the historical, imperial Rome of Justinian's time.

Search, miserable! All the shores around Thy coasts, and then within thy bosom look, If peace in any part of thee be found.

What does it profit, that Justinian took

Thy bridle in hand, if empty be the seat? (VI 85-89)

The personal peace of the spirit was Dante's focus here and what he expressed of the development of the culture. The concept of peace would be stillborn if present-day Italy would not effectively embrace the peace currently proscribed and claimed by the current power brokers.

In the Paradiso, Dante heard Justinian explain his rule in Rome and the ambition of the Guelph and Ghibelline desire to break the empire in two. Past and present depictions in the three Cantos VI worked like prophesy, past and present guiding the future. The structures of society in the early Renaissance were not yet strong enough to strengthen the concept of peace, which required the voice of the populace to carry the desire for peace to the entire culture. Dante resolved the Paradiso by closing the circle of his spiritual experience

To the high imagination force now failed;

But like to a wheel whose circling nothing jars

Already on my desire and will prevailed 
The Love that moves the sun and the other stars (XXXIII 142-145)

The regional socio-political structure would not hold together the society long enough for the peace to reign.

Marsilius (Padua) wrote not dialogically, but prescriptively as would the writers after the period of Westphalia. They would represent the culture by prescribing the nature of responses to each other. First, though, Marsilius in the Defensor Pacis identified peace as an ideal for attainment in a straightforward way.

The fruits of peace or tranquility, then, are the greatest goods, as we have said, while those of its opposite, strife, are unbearable evils. Hence we ought to wish for peace, to seek it if we do not already have it, to conserve it once it is attained, and to repel with all our strength the strife which is opposed to it (5).

Health is the best disposition of an animal in accordance with nature, and likewise that tranquility is the best disposition of a state established in accordance with reason (9).

The concept of peace would point to the tranquility of the socio-political realm as analogous to the natural health of any organism.

Marsilius finished Defensor Pacis in 1324, three years after Dante's death. For Marsilius "tranquility," his opening word in Discourse One, meant "peace." Even though Marsilius was officially regarded at the time as a subversive influence, the overriding idea in this work was an approach to equilibrium, a characteristic of order, which was a concern throughout the Tuscan region, especially in Siena. What he attempted to bring into equilibrium were values, conflicts, and power relationships. The first of three "discourses" in the Defensor Pacis treated human nature and reason in matters of state. Reason taught "the general causes of civil peace and strife" (xxi). Marsilius, an Averroist, "maintain[ed that] the relation between reason and faith,...applie[d] to the sphere of the 
practical" (xxii). He saw civil happiness as the underlying goal of all human acts (7). The state provided the order to balance "actions and passions" (xxiii). In Siena, peace simply represented order. The concept of peace sought to bring about good living. The state "enable[d] men to achieve,... [was] the scene and regulator of strife,...control[led] and settle[d] conflicts" (xxxi).

The medieval mind differed from the Roman and Modern minds. The difference was one of perspective and appears in the available artistic evidence. The early Renaissance, still in the sway of the medieval point of view, was both far from and too near the point of view of antiquity to be able entirely to evolve far beyond it intellectually and artistically. Antiquity held the heritage of western culture, which explains why Rome remained a model, a presence, and an aspiration at the same time. Erwin Panofsky noted “...it was impossible for [such as the Tuscans] to evolve the modern idea of history, based on the realization of an intellectual distance between the present and the past, which enables the scholar to build up comprehensive and consistent concepts of bygone periods" (51). Creating a guide, Dante through his creation came close to expressing in his time a contemporary idea of history, with a fresh viewpoint.

Less allegorical than Dante's Commedia and more of a treatise was Marsilius' Defensor Pacis. This work commented on the period's state of affairs in such a way that it echoed the incisive Roman point of view and provided a link to the perspective of early Modern writers to come, such as, Hobbes and Locke, in the types of treatises they would write. According to Alan Gewirth, in his introduction to the Defensor Pacis, the thematic conclusions of the treatise include the following: "1) The state is a product of reason and 
exists for the end of men's living well; 2) political authority is primarily concerned with the resolution of conflicts and is defined by the possession and structure of coercive power; and, 3) the sole source of legitimate political power is the will or consent of the people" (Gewirth xxx). Marsilius justified his title for the book "because it discusses and explains the principal causes whereby civil peace and tranquility exists and is preserved, and whereby the opposed strife arises and is checked and destroyed" (Gewirth 431). Marsilius noticed the presence of the significant quality of tranquility in the concept of peace.

After Siena, the idea emerged of the culture as similar to a view of trees in a forest. Until that time, though, the west had entertained a perspective that looked out as if at a collection of trees and saw a forest. The west's perspective had been far-sighted. The Sienese power brokers, the Nine, following the example of Rome, viewed the commune as an individual organism whose health and continuance were achievable by addressing the fact that the concept of peace depended on their rule and allowed for the prosperity of the entire commune. The dimension Siena added to the Roman concept of peace actually brought the concept of peace to a level that was almost tangible to the citizenry of the commune. Being a commune rather than an empire as Rome was, Siena's task seemed easier to accomplish. All of the commune could better feel the effect of the presence or absence of political tensions. As such, the Nine could feel it, too. What might not have mattered in Rome, mattered then in Siena where governance differed by being more closely affected by its people in comparison with imperial Rome; however, the nearness of Siena in time and geography to the city of Rome and the heritage Siena could claim as 
having been founded by the Roman soldiers made Sienese legitimacy, linked to the concept of peace as if it were a new Pax Romana, an easy connection to make.

To detect a sense of the way in which the concept of peace provided the opportunity to exemplify a point of knowledge in each of the three periods, one may turn to the way artists expressed the emotions and sensibilities of their time. In the case of Siena, the artistic expression of Ambrogio Lorenzetti's frescoes, being commissioned works, served the ruling elite. "The Sienese had a [great] tradition...of cultural investment through government and civic rather than private display" (Bowsky 293). In the Allegory of Good Government, the concept of peace emerged strongly through his depiction of the image of Peace and her relationship to all the figures in the frescoes. (See Figures 1-3.) The surface view in the first of the three frescoes that make up the Allegory of Good Government recorded the psychological and social characteristics of Sienese rule rendered as representative myths. The Nine had commissioned the Lorenzetti frescoes to adorn the Palazzo Pubblico where they conducted their governmental business.

Lorenzetti's frescoes contain visual metaphors and juxtapositions that suggest symbolic hierarchies within the culture. Of viewing images Jas Elsner wrote that in "looking at an image, a beholder is assessing a view of the world already created by an artist. In the viewing of art, the artist's own creative viewing of objects is a critical mediator between the beholder and the world" (4-5). The viewer interested in the development of the concept of peace comprehends the depth of references from the culture even though the intent may be current to a single time period. Yet the possibility of a leap made in the mediation allowing artist and viewer to journey into cultural 
meaning used art as a key to discover, as Arnold Hauser wrote, "a change of attitude" (465). The artists and writers expressed their imaginative intuition in imitation of "the beautiful or moral aspects of the world, or else any aspect without discrimination" (M. H. Abrams 7). They all depicted cultural intuition, attitudes, common sense, or even the "science," that is, the knowledge or understanding of their time.

In Siena the frescoes of Ambrogio Lorenzetti, commissioned as a program of frescoes, directly underscored and promoted the idea that the Nine were not only keepers of the peace that had been operating since 1271 , but they were possibly the actual source of the concept of peace in the first place. Having passed the 60-year mark of their rule, they frequently took opportunities to promote their significant achievement of peace. The Nine commissioned Lorenzetti to begin painting the frescoes, "didactic civic art," in 1337 (Waley 67). By this time, one could assume the civic memory might have dimmed regarding the particulars of the manner in which the wars of the $1260 \mathrm{~s}$ had ended. Much had settled into regional lore by that time and the Nine, if depicted properly, could be shown as creators as well as maintainers of the Sienese peace and could indicate their heritage by juxtaposition to previous rulers. This linkage and the artistic rendering of it symbolically in the frescoes was reminiscent of Vespasian's own tactic of placing his Templum Pacis in direct juxtaposition to the Forum of Augustus, thereby investing his own forum with the peaceful and orderly spirit of the former. The connection of Vespasian's rule to the Augustan one was clear and desirable because Augustus's unique act had been to close the doors to the Temple of Janus.

As the Nine neared the final decades of its rule, its members found themselves under siege at home and in the region since their control of the contado was weakening as 
was the prospect of their citizens' safety in the region. Even though the actual members of the Nine served terms of specific length and were elected from a larger pool of business and civic leaders, the structure of the ruling body had been stable. However, this was not a group who dictated freely. As such, their final two decades as the power brokers in the commune saw them employing a tactic used effectively in Roman days by Augustus and Vespasian. While their rule had been successful and arduous in combination as happens in local governments, peace in the region had coincided with their rule. It was the Nine's generation of rulers who held the keys to heritage, legitimacy, order, and the concept of peace. Such a strategy Arnold Hauser suggested had been more reminiscent of medieval societies where the generations were more unified, less competitive, than they had remained in the early Renaissance (46). Still the Nine made the effort to put the concept of peace to use in a Roman way, indicating its importance conceptually within a society as depicted in the Lorenzetti frescoes. This tactic did not work conclusively. As was evident in the Modern eras, the concept of peace gained strength and force when it emerged from lower in the social order than the ruling class. Within 15 years, the Nine were out of power. In Siena, the message of peace had come from the top, rather than organically from within the society. One can not trace the emotional arc of the desire of the citizens of nations without artistic renderings of national or civic direction away from war. Looking back to the early Renaissance from the $21^{\text {st }}$ century, it is easy to discern that the artists and the writers were the group among the populace who were able to supply significance to the eras in which they worked. For the future, theirs were the voices and representations of peace that at times indicated more cogency in events than the custodians of order, the Nine, could provide themselves. 
According to Diana Norman, the Nine had conducted a program of commissioning art projects for the public spaces in Siena (100). In 1337 when the Nine commissioned Ambrogio Lorenzetti to create frescoes on the subject of good and bad government, the Nine were linking themselves to the idea of successful governance and the concept of peace together suggesting their own lineage drew from the twin heritages of wise and historical rule as well as a peace like the Pax Romana, which would be seen as directly attributable to their own socio-political efforts in their region. Norman surmised that the Lorenzetti frescoes "should be understood both as an expression of Siena's civic ideals for the members of the city's magistracy who met there to formulate policy and as a means of impressing the numerous foreign dignitaries who were received in [the Sala dei Nove]" (98). As an example of the union of good rule and the concept of peace, the frescoes delivered a didactic message and perhaps served as a reminder to the Nine themselves of the concept of peace and its heritage as represented by them rather than the other way around. Either way the message came through that the Nine were crucial to the success of the peace in Siena and they were able to trace their heritage for legitimacy through the history of their region rooting it in imperial Rome as well whose government had planted the seed of the commune in the first place. In Sienese lore, Aschius and Senius, twin sons of Remus, had founded Siena establishing an incontrovertible link to Rome (Southard 281). Even so, the late medieval political thought behind the message of the frescoes was one of civic management rather than one suggesting peace for humanity. The appearance in the allegorical panel of the fresco of the four cardinal (Roman) virtues and the three religious (Christian) virtues offered quasi- 
religious associations that served as a compromise union of pagan and Christian points of view. Such a combination of points of view appeared in Dante, also. Additionally, in reference to the Roman view of governmental responsibility, the frescoes "convey vividly that Siena's government was not merely a matter of abstract, universal values but involved the active participation [and legitimization] of the citizens themselves-even if only those drawn from a particular social group" (Norman 100). Certain details, wrote Norman,

relate to the civic legislation of the Nine for facilitating trade and commerce within the city, encouraging the production of food in the countryside and maintaining roads and bridges there... during their period of government were confronted with threats to their political authority both from factions within Siena itself and from outside powers such as Ghibelline Pisa, which in 1332 laid waste to Sienese territory within a few kilometers of Siena itself (104).

In order for the Nine to satisfy the commune's sanctioning of them as governing group, they needed to project an image that they still could protect Siena from regional threats.

The frescoes painted by Ambrogio Lorenzetti have borne names that changed over the centuries and included the following: War and Peace; Allegory of Good and Bad Government; and, Allegories of Justice, the Common Good, and Tyranny. "To decipher successfully the event represented in a historical painting, one must know the event, but one must also know in advance where to look for it" (Klein 153). One must also know the "principle of unity...that offers the most inner and outer coherence" to the interpretation (154). The Middle Ages had been interested in the classical motifs not just for the representation of classical themes (Panofsky 41). One saw these themes in Sienese paintings of the period where artists appropriated classical images and motifs to serve and ballast themes current to them. Pagan symbols mixed with classical and theological personifications. This mixing represented the mediation between "representational and 
textual tradition(s)" (43). At the time in Siena the currency of ideas put forth through a knowledge of classical themes an iconography that represented a structure at work in the commune. As Erwin Panofsky explained, when this happens "in the Italian Quattrocento, it was from this complex and often very corrupt tradition, rather than from genuine classical sources, that many people drew their notions of classical mythology and related subjects" (44). Here the focus was on "related subjects." The Nine could invest the commune's faith in their legitimacy, in their presence and rule with an authority attached to more than one tradition. They took the opportunity to root solidly the connection from their rule of Siena to Rome as a foundation for their approach to rule in the commune. The virtue of their rule stretched back to classical and theological abstractions that persisted in defining good government for all eras. The idea of the Nine became a natural presence, a natural force under whose organic leadership the commune prospered.

Once the civilization of the Middle Ages had established its own standards of socio-political structure and found its own methods of artistic expression, it became impossible to enjoy or even understand any phenomenon which had no common denominator with the phenomena of the contemporary world. It was "self-evident that this reintegration could not provide a simple reversion to the classical past. The intervening period had changed the minds of men, so that they could not turn into pagans again; ...their art could not simply renew the art of the Greeks and Romans. They had to strive for a new form of expression...related and indebted to both" (Panofsky 54). The culture and the concept of peace along with it had to expand.

The frescoes had a focus that represented the features of the Nine in symbolic and metaphorical form. The frescoes comprised three discussible parts. Part one, often 
referred to as the Allegory of Good Government, showed the seven Virtues, Peace, and other historical figures arranged either on or near a dais. In the Sala dei Nove where the frescoes adorned the walls, part two, Good Government in the City, was on the wall to the right if the viewer faces the Allegory of Good Government. Connected to the right of part two was part three divided only pictorially in the fresco by a wall. This part depicted Good Government in the Country. Additionally these current titles described their respective parts. The Allegory of Good Government sat above the door the Nine used to enter the room where they met with others when conducting the business they undertook. In this light, whomever met with the Nine may have faced them in the flesh as well as their symbolic representation on the wall. One may imagine the combined effect of seeing the actual Nine and the idealized Nine.

There were three levels of figures in the fresco. In the central area of the fresco Lorenzetti seated most of the figures. From left to right was Justice with her distributive and commutative aspects. The viewer received an immediate impression from the two angels on either side of Justice that they indicated clearly how to administer justice, spend public money, distribute honors and public offices, and mete out punishments. On the viewer's left of Justice, Distributiva distributed punishments by crowning the head of one figure and chopping off the head of another. On the viewer's right of Justice, Commutativa, offered "spear and a staff," the symbol of public office, to one citizen and put money into a box for the other citizen (Cariola 66). In the context of Sienese life from 1337 through 1339 , these functions contributed to the sense of order in the commune. Vertically Justice sat midway between Wisdom above and Concord below. 
The inscription over Justice's head, between her and Sapientia above her, was diligite iustitiam qui indicatis terram, "Love justice you who govern the world," the first line of the book of Wisdom. This inscription provided the foundation concept of the Allegory, because it represented Sapientia. Justice provided the backbone to order, which was the foundation of the concept of peace in the context of a socio-political framework. Concordia just below Justice received the ropes (cords) from the scales of Justice, which then passed through lower-order figures toward Ben Comun, the Commune of Siena, who was the largest figure in this panel of the fresco, the Allegory. With this figure Lorenzetti established the seat of order, portraying the arbiter of wisdom to whom all vestiges of civic justification and sanctioning flowed. The image of the wise pater was a holdover from the Augustan Age and the effective Roman emperors who followed the Augustan Age in Rome. The cords that passed through the hands of the 24 led as a single cord to the imposing figure of Ben Comun, an old man, dressed in the colors of the city, black and white, which he anthropomorphized. The letters around him, CSCV, identified him as Commune Senarum Civitas Virginis (Commune of Siena, City of the Virgin). The cords linked him directly to Justice and Concord and all the Virtues flanked him feeding their influence and aspects into him from which he partook and returned wise, just, and peaceful rule.

Moving to the right from Justice were Peace, Fortitude, Prudence, "Ben Comun," Magnanimity, Temperance, Justice. Above Ben Comun, were circled Faith, Hope, Charity. (The two extra figures, Magnanimity and Peace, were additions to the four Cardinal and three Theological virtues. All together made nine symbolic and metaphorical virtues and ideas that guided the rule of the actual Nine in their 
management of the peaceful commune.) Images in this panel of the fresco related to the ideas of concord, order, and the myth of the founding of the Commune. For example, the twins and the she-wolf together connoted Rome who by legend had built Siena as an outpost near Rome during the days of the Republic (Howells 130). By extension whatever provenance Rome offered culturally applied directly to Siena, a Roman outpost that survived.

The features of the Allegory of Good Government represented the Nine in symbolic and metaphorical form and revealed their gestation as a ruling body. There were great western themes depicted in this fresco panel. Magnanimity was an Aristotelian concept. Distributive and Commutative Justice were formed from Thomistic-Aristotelian themes (Bowsky 289). The ruling body that served previous to the Nine was represented by Lorenzetti in such a way that they seemed to offer their authority as if they had been waiting to make room for and give foundation to the Nine, as if the day finally arrived when the Nine could take hold of the reigns of power. These previous rulers were The 24 Priors, who ruled from 1236-1271 (Bowsky 289). William M. Bowsky stated that the Nine were Guelph and the Priors were Ghibelline, so the fact that the two opposing factions apparently were in agreement on the succession of rule underscored the idea of a harmoniously governed commune as well as a well-governed region, which was the immediate point of the frescoes when they were created. The great underlying message of the frescoes was propagandistic in favor of the legitimacy of the rule of the Nine and their success in bringing and maintaining the concept of peace in the commune.

The propaganda point of the fresco which promoted this image of the Nine signified the idea that they had maintained peace in the commune since 1271 . The look of 
the Allegory of Good Government justified their viewpoint. As a figure in the fresco, Peace was the main conceptual element of this first part of the frescoes, the Allegory of Good Government. The concept of peace was the central thrust of the Allegory. The figure of Peace herself drew the most attention among the other figures. Due to her presence, the others coalesced around her. Lorenzetti lit her differently from the other figures near her and her light seems to shine across the room to the Good Government in the City where the dancers appear in the light she casts.

Peace was the conceptual figure around which Ambrogio Lorenzetti planned the fresco. Since the frescoes were commissioned, their subject matter was set by the commission. "The choice [of subject matter was] crucially significant for understanding [the Nine's] own conceptions of its duties and its role in the life of the commune" (Bowsky 288). However, the depictions and realizations of individual elements and figures may or may not have been so strictly determined. The image of Peace seemed to be a specific artistic rendering of a concept rather than one that explained the legitimacy of a ruling group whose authority proceeded naturally from predecessors. Lorenzetti had depicted most of the figures flatly and with a symbolic sense of their historical generation. Peace alone seemed more conceptual and forward-looking since she was not tied to the past, but rather to a desired future. She cast her light toward the dancers in the City panel.

The purpose of the fresco was to refer to the past investing the Nine with the security of tradition and history. Roman emperors would never have had to create such a representation of their rule. Imperial power brokers did not need to display the properties of their rule. However, in Siena, a small community where power was invested in a ruling 
body to which power brokers were elected, a billboard for their significance to the commune served a purpose.

Therefore, the most important and iconic figure of the fresco was Peace, draped in white on a couch while reclining on a mound of weapons. As a figure, she was set apart by her position in the fresco as well as by her attire. Olive branches garlanded her head and she stabilized a single branch in her left hand. There was an iconological thought behind the fresco as there was behind the paintings of the period, which expressed the Sienese culture. In her image something allegorical, too, imparted itself as an expressive quality as in the tradition of Iore. Iconographically, to use Panofsky's term in relation to the way Lorenzetti renders Peace, the lore was Roman. The depiction of the figure of Peace in the fresco was reminiscent of figures of Securitas presented on the coinage of the Rome of Vespasian's time, who presented a well-promulgated imperial image. In the panels of the fresco, Peace has a cognate image depicting communal life in the country. As Lorenzetti chose, that figure, too, is Securitas. Peace and Security watched over the rulers, the city, and the countryside.

For the west the concept of peace began to contain significant meaning in Siena. Chiara Frugoni traced the iconography of peace to Roman coins depicting Securitas, the figure from Rome that related directly to the concept of peace. In the frescoes, Lorenzetti used Securitas to impart of sense of watchfulness in order to preserve the tranquility and peace of the transition from city to countryside, suggesting the penalties for disrupting that tranquility. Lorenzetti's image of Security holds "a little model of a hanged man in her hand just outside the city gates painted according to the classical iconography of Victory" (A Distant City 70). The rule of the Nine had bite in its authority. 
Security and Peace were the two foundations of concord and civic control. They characterized the stability of the city reaching beyond into the countryside. In the fresco at the juncture between Good Government in the City and the Country, Security holds a scroll that expresses the state of affairs of the concept of peace as an idea the Nine wanted to convey. This was the state of affairs contemporary to the painting of the frescoes. Her scroll bore a legend that related directly to the Sienese sense of peace and tranquility. "Without fear let every man freely walk,/And working, let everyone sow,/While such a commune/This lady [Securitas] will keep under her rule/Because she has removed all power from the guilty" (Bowsky 290) This legend told the citizens of Siena exactly what the concept of peace meant in a period when they were not fighting a war and in one brief statement strengthened the position of the Nine, who were good administrators, as power brokers. The Nine claimed their ability to secure the peace and surety of the commune in order to convey the sense of their inheritance from imperial Rome.

Two thoughts remained expressible, one of which came from the cartello beneath the Allegory of the Nine:

Wherever this holy virtue rules

She induces to unity many souls;

And these, gathered for such a purpose

A common good for their master undertake;

Who, in order to govern his state, chooses

Never to keep his eyes turned

From the splendor of the faces

Of the virtues which around him stand.

For this, with triumph are given to him

Taxes, tributes, and lordships of lands;

For this, without wars

Is followed then by every civil result,

Useful, necessary, and pleasurable (Bowsky 289). 
These thoughts followed from peace or only in peace did there follow matters "useful, necessary, and pleasurable." Another thought obtained from C. J. Campbell, who observed Lorenzetti's politics of peace and its use as a conduit to both the past and future of the culture.

Returning to the larger picture I would observe that...[Lorenzetti's] representation of the peaceful commonwealth has everything to do with an idea of the rebirth of human culture, and...it owes something to the remembrance, however fragmentary, of ancient texts... (Campbell, 13).

Facing the Allegory of Good Government, one may see the fresco cycle completes itself opposite the Good Government panels with two panels devoted to the Allegory of Bad Government. There the effects of disorder appear in negative correspondence with those of the Allegory of Good Government: Tyranny with War, Treason, Fury, Discord, Fraud, and Cruelty. Therefore, the Bad Government panel among the frescoes, which depicts mercenary raids, was not entirely without foundation in real life in Siena at the time. Daniel Waley reported the continual presence of bandits in the countryside. With the exception of the allegorical nature of Bad Government, there was truthfulness in communal depictions in Lorenzetti's city and countryside. Plus, he quite accurately presented the visual geometry of the commune and contado when compared with photographs of present-day Siena. Yet, the Bad Government fresco provided a fanciful aspect to the entire fresco cycle. In the frescoes' completeness their allegorical nature, then, expressed both positive and negative aspects of Sienese government. The Nine needed to demonstrate the contrast and how their good government overcame the adversity of the alternative. Of the depictions, one must have assumed a certain amount of artistic license, because the Nine were registered as part of the Sienese lore even though they were the active rulers of the commune. They were made characters in their 
own Palazzo. Yet, "characters appear more interesting than action, complex and eccentric natures more gripping than simple and normal ones, problematic relationships poetically more productive than straightforward conflicts" (Hauser 260).

The image of Peace, rooted in stability and order even lighting the town, promoted the expression of the maintenance of order of which the Nine were reminding their citizenry. Heinrich Wölfflin when writing in his Principles of Art History of the movement in art history from the Classical to the Baroque would say of the fresco that its artistic execution is Classical, but through the three parts of the Allegory, there was movement pointing from the Classical (a closed form) to the Baroque (an opened form), pointing beyond the early-Renaissance period into future phase of western culture. Lorenzetti accomplished this forward-looking achievement by rendering Peace not in the limited classical fashion, heavily outlined, static, and representing a specific type. Lorenzetti expressed in Peace a limitless, numinous quality that served to allow her light to shine into the city and connected her with Security watching over the entire city and countryside. There was an expansiveness in her shape, rounded, gazing differently than the other figures, guarding weapons for the contemporary viewer and defining the extension of her role into the future. When viewing the Allegory her nature partook of characteristics of all the other virtues on the dais. She ensured an equivalence of importance and significance among the figures in the foreground with the figures in back. Given that effect, in all of Siena's contado, Peace and Security promised on behalf of the Nine there was no fading of influence the further out one might go.

Siena seemed solid, unified, stable, but because of its small size in the region, aware that its security was subject to threat. Rome, of course, had had its own city, but 
beyond lay its empire, a larger expanse than the Sienese contado. However, one could comprehend a unity posited, at least, in the theme of the frescoes, a clarity of subject the art of classical Rome did not share. All the parts worked together to underscore a sense of a single theme, that is, that Siena's Nine represented good government and quite possibly themselves as maintainers, at least, of the concept of peace.

The art of the three cultural periods under discussion in this dissertation allowed a nationalistic focus on the concept of peace. Heinrich Wölfflin made a sufficient statement in this regard. "We cannot forthwith base a general judgment of a national type on one single epoch. Different times give birth to different art...[for example] the central idea of the Italian Renaissance is that of perfect proportion... perfection at rest within itself' (9). In the Sienese period, the art is near to expressing a new opening to cultural meaning toward which Lorenzetti reached unwittingly. The image of Peace stood out as the illumination of the commune, perhaps the government, as if to say in this room Peace thrived along with security, order, and the seven cardinal and Christian virtues. Peace was an indicator of, a measure of successful rule. Wölfflin continued, "the relationship to the world has changed, a new domain of feeling has opened, the soul aspires to dissolution in the sublimity of the huge, the infinite. [There will be] 'emotion and movement at all costs'" (10). Peace, conceptually and pictorially, was the element of the fresco that pointed ahead toward the Baroque mode and a successive social order. She appeared in a relief the other symbols in the fresco did not share. She corresponded to no real historical aspect of the Nine and their tasks. "Every artist finds certain visual possibilities before him, to which he is bound," especially when commissioned, but 
"vision itself has a history." The beginning developments of the concept of peace were expressed here (Wölfflin 11).

Lorenzetti rendered Peace in a geometrically rounded shape. There were areas of the allegory, parts where Lorenzetti seemed to see in patches and shapes instead of simply defined lines or geometrical outlines. However, those patches existed as suggestions or possibilities in the cultural makeup. This was still art that depicted objects, showed what was either a physical thing or a representation of a thing or an ideal of a thing (Danto 423). The culture was still somewhat a "captive of cognitive darkness" out of which it sought to extricate itself (Danto 418). Still, waging peace seemed to be in a stage of becoming a propagandistic part of the Sienese civil code. The Nine allowed the message to come through even when they as rulers were on guard constantly to maintain their peace and significance in the maintenance of order.

Tuscany was significant in the development of the west culturally and the development of the concept of peace, as Arthur Danto reminded readers from Giorgio Vasari, because the Tuscans had regarded their image as if it was that of a chosen people's. Of Vasari, Danto characterized the Tuscans as a people with great aspirations to knowledge, but possibly without the ability to achieve them (416). In Siena, the city without a Michelangelo or a Dante, their desire for achievement and maintenance of order was crucial. The world there was Tuscan as the world had been Roman in antiquity, smaller in the early Renaissance although similarly concentrated in cultural focus. In the west, the idea of the world increased slowly in size and scope. The slow progress definitely affected the west's ability to comprehend and arrive eventually at the concept 
of peace as a solution for conflict. Artists such as Ambrogio Lorenzetti contributed to their society's progress, however, unaware they were of their own prescience.

William M. Bowsky articulated some possibilities of official treatment of the populace in his discussion of the place of art in the commune. Only the genius that served the common good received rewards. On another note, Bowsky made a connection to a level of paganism in Siena that did not manifest itself in Florentine art, such as, the shewolf--visible in the Lorenzetti fresco. In Siena, "communal support and encouragement" extended beyond mind and spirit to include "the totality of the urban environment" (294). A sense of civitas was total in the way the Romans might have expected it from their full citizens, the patrician class. It was important that citizens contribute to civitas. From the first half of the $14^{\text {th }}$ century, city growth was planned and not left to grow spontaneously or according to the whims of those in power or with money. Artistic expression served communal growth and the development of the concept of peace. In contrast with Florence, Sienese citizens were more public- and civic-oriented. They enjoyed the artistic virtues, but did not emphasize them over other aspects of the communal life (260).

In the aftermath of the Nine's rule, socio-political dysfunction in the region returned. Norman Davies in his history of Europe summarized the events. "Emperorelect, Charles IV of Luxembourg, visited the city in March 1355" (299). "The end came on Wednesday, 25 March, when 'all the city was in arms.' Charles received a fearful signory of Nine, withdrew their staff of office, and cancelled all the promises he had made to them" (301)."Their regime had fallen, but the Nine had built well. Many aspects 
of their style of administration and rule continued almost uninterrupted" (303). "Their style was, if anything, a pragmatic one that emphasized the institutionalization, formalization, and regularization of practices and offices that worked. The aim was efficiency and effectiveness, successful functioning" (307). Ideals were crucial to the commune of Siena. "Ideals were held most strongly and propagated most vigorously by the ruling oligarchy; but they were not spurned by the governed" (313). "Having created a patriciate of public service, [the Nine] strove to augment the public good-admittedly, as they perceived it. [They] labored hard and sincerely to add to the well-being and beauty of their city" (314).

In the end days of the Nine regime, Caferro reports in Mercenary Companies and the Decline of Siena, that from the 1340s through 1399, payment of bribes were made to various marauding companies (44-45). Additionally, payments and costs were associated with protections necessary for the commune. "If 'valor' provided neither savings nor freedom from future attacks, what was left for the Sienese to do? One of the most intriguing and little-studied actions was the formation leagues for mutual defense. Siena joined numerous leagues including those of $1347,1349,1353,1354,1361,1366,1371$, $1374,1380,1385$, and 1389" (99). Clearly from the end of the Nine's regime, coincident with the Black Plague, and through the $15^{\text {th }}$ century-the mercenary raids continued until 1399. The peace maintained by the Nine had slipped away. The 1385 agreement was made in November "between Siena, Bologna, Perugia, Florence, Pisa, and Lucca...' [to join] together not only in spirit but in written contracts'...to protect themselves from the ravages of the companies" (99). 
These were the first disturbances in the wake of the Nine's rule. All over Europe in the $15^{\text {th }}$ and $16^{\text {th }}$ centuries, however, there was religious fervor. The concept of peace suffered in the wake of the shift in balance between the Islam and Christian empires from the west in Spain to the east in the Ottoman Empire (506). The Counter-Reformation "interacted with all the other great phenomena of the age" (496). Accompanying the resurgence of a religious ethos, was "a new militancy" that dealt a blow to the concept of peace on "St. Bartholomew's Eve on 23 August 1572, when 2,000 Huguenots were butchered in Paris" (502). Religious fervor again drove the wars of the $16^{\text {th }}$ and $17^{\text {th }}$ centuries. "Protestant fears of Catholic domination surfaced in the Wars of the Schmalkaldic League in Germany, 1531-1548, which ended the Peace of Augsberg; in the French Wars of Religion, 1562-1598; in the Swedish civil war, 1598-1604; in the Thirty Years' War, 1618-1648" (506). 


\section{CHAPTER IV}

\section{WESTPHALIA}

In the period following the Peace of Westphalia (1648), the west again began to enjoy "an atmosphere favorable to activities of the mind" (Zampaglione 135). Writers began to discuss peace, which shaped the quality of the continental conglomeration of newly founded European states. A treaty marked the beginning of the Westphalia period; however, movement for change within the social consciousness preceded the Congress of Westphalia and the placing of signatures onto the document. The end of the Thirty Years' War had ramifications for socio-political systems in Europe. One ramification affected the reinvigoration of the development of the concept of peace. The slow emergence of the voice of the populace as a counterpoint to the official voice of the power brokers had effects that continued to be felt through the 1950s, the end of the survey covered by this dissertation. Among those early-Medieval voices was the pre-Westphalia writer, Hugo Grotius, whose writings focusing on Natural Law, Rights of War and Peace (1625), preceded the Treaty of Westphalia and conceptually heralded the same type of cultural conversation in the European dialogue that emerged during the times of Hobbes and Locke.

For Grotius, a predecessor of Hobbes and Locke, the human mind bound all of Europe together at all times and through his conceptual thinking the development of the concept of peace gained a foundation in Law and Reason. Even though his focus was on 
peace in society, he sought "to discover when, how, and by whom war may be justly conducted" (Hill 8). Grotius, too, saw nations as aggregations of individuals, to which applied the psychology of individuals. The reason of the individual became the foundation for Grotius' construct, a system of universal law, which applied just as well to the state of war as to the concept of peace. David Hill writes of Grotius' Rights of War and Peace.

As the law of human nature is universally binding wherever men exist, it cannot be set aside by the mere circumstances of time and place, whence it results that there is a law of war as well as a law of peace. As this law applies to the commencement of armed conflicts, war is never to be undertaken except to assert rights, and when undertaken is never to be carried on except within the limits of rights. It is true that in the conflict of arms laws must be silent, but only civil laws, which govern in times of peace. Those laws which are perpetual, which spring from the nature of man as man, and not from his particular civil relations, continue even during strife and constitute the laws of war. To deny these, or to disobey them, implies a repudiation of human nature itself and of the divine authority which has invested it with rights and obligations. To disavow the imperative character of these perpetual laws, is to revert to barbarism (9).

The natural law Grotius conceived was tied to reason or human intelligence. What gave the conception of natural law its force was the largeness of its voice, by invoking the larger order of God. That voice translated it to the contemporary socio-political structure of Grotius's time. Crucial to this structure was a system of natural law that included a notion of laws of war. Another law, conventional law, formed the law of contracts and agreements, what would be classified later as "constraints" by Hobbes and Locke. For Grotius these laws distinguished jurisprudence in socio-political settings from questions of ethics and morals. Certain problems accompanied Grotius's scheme. His arguments may have justified slavery, the will of the conqueror over people, and a "sovereignty with supreme power...as the conceptions of his time...had not yet grasped the idea of the state as a moral organism" (Hill 11) All of society was in some state of 
turmoil and Grotius, writing before the Treaty of Westphalia, wrote to his time, his viewpoint advancing his culture. He was a transitionary thinker who comprehended the necessity of the larger and successful socio-political order. As a result, his reasoning could come forward into the late-Modern era to justify the claim that the state had a responsibility to strive for peace in its program of establishing moral organicism. However, there was no sense of neutrality for Grotius. Still, in the Westphalia period natural law was even more important than God (Grotius 22). Grotius suggested, "as a final settlement of all discussions, I demand restitution according to the law of nations" (75).

By the time of the immediate post-Treaty period (1648), there developed an overt struggle between those governing and the populace, who over the next couple of decades began to insert their ideas into the culture. The Treaty of Westphalia itself was a document that established the divisions among nations giving Europe a chance to accept itself as a collection of specific nations with independent governments. In the formulation of those governments arose ideas from within the populations of the nations' voices and popular wills that sought to articulate the methods of governance. For the new political wills to achieve authority required struggles, one of which was over a constitutional movement started by the Cardinal de Retz in the war of the Fronde to protect the populace from the strengthening of the nobility after the Thirty Years' War. According to Derek Watts, in France, for example, after the first half of the $17^{\text {th }}$ century, "the 'optimistic' view of man began to lose ground, and by 1660 it could even be called a minority view" (14). "Religious faith is no longer seen as a viable force in politics, and now only one law is regarded as effective between nations: the law of self-interest" (17). 
Much of de Retz's thinking, contrary to that of Grotius before him and Hobbes and Locke after, "was essentially moraliste rather than politique in its fundamental bent" (Watts 214). However, de Retz set a tone for the emerging political wills among the populace with his utilization in the Fronde of certain political forces where he achieved an emotional impact societally. These forces included "the willful dissidence of the nobility, the spirit of independence within the church, the constitutional restraints assured by the supreme court of the parlement, and the turbulence of the common people" (Salmon 2). The Treaty of Westphalia in its dividing of lands and setting up of nations did nothing to guide the internal shaping of those nations and their groups. However, on a positive note the Treaty had wisely eschewed blame for the wars. As a result, the new nations in Europe could establish themselves with a peaceful start. It was the aftermath of a series of devastating wars that lead to the re-evaluation of the socio-political framework in Europe that brought forward new thinking from writers, such as Hobbes, Locke, Rousseau, and others, while those in positions of authority throughout Europe were trying to maintain as absolute a power as the populace would cede to them. The popular voices of this era gained a strength after the Thirty Years' War that those citizens governed by the Nine in Siena were unable to attempt in their time.

The concept of peace in the Westphalia period differed from its Roman and Sienese versions, adding to the western frame of mind a viewpoint and an expectation of real differences in quality-of-life for peoples within a nation. Rome had commanded an empire. The Sienese rulers had managed a small commune. In the new post-Treaty Europe, peace was no longer a word useful solely to a governing body for its needs. Peace still exposed the desire of larger state governments to strengthen and maximize 
their hold on rule. However, the voice of the populace emerged in the culture for the first time across national boundaries expressing ideas on the uses of the state as a mechanism for ensuring more ethical governance and better living. These ideas were more easily promulgated after the Treaty of Westphalia.

In this era the concept of peace first emerged-years earlier than the period of the drafting of the Treaty of Westphalia (1644-1648)--as an expression of desire and need on behalf of the populace. A debilitating state of destruction among the nations of Europe had preceded the rise in importance of the popular voice in early-Modern western culture. According to the thought that followed in the wake of the Treaty of Westphalia the predominant voice among the writers was one of Reason as displayed in the writings of Hugo Grotius. There had been a shift in political power from the early-Renaissance governments of city-states to a style of governments of nations. This shift signaled a response to events, but complicated and modernized the culture. Across nations arose potential population groups of various ethnic origins together shaping national identities (Davies 565). The nations themselves faced more differences within their borders than the Renaissance city-states ever did. In the Westphalia era there was understandably more at stake between any two nations than a mere rivalry within a region. Furthermore, within any given nation the numerous ethnic groups collectively began to see themselves as contributors to the strength of the nation. Additionally the territory a nation contained within its borders became important for containing valuable natural and human resources. Nations needed to control their resources. Sometimes greed ignited bellicose urges leading to an attempt to annex more land and resources from another nation, which was an effort that violated relations and the peace between those two nations. The result was 
that more resources generally brought more riches, which themselves funded more armies for the protection of a nation's resources and the defense of its people.

In the Westphalia period, peace, as a term, described the relations between two or more nations, which functioned because of the order brought to Europe partly by the Treaty of Westphalia. As in other periods in the west, much of what moved the machinery of the culture was still visible through the arts, which frequently expressed ahead of the official governmental view the significance of events and how they actually caused the culture to evolve.

Michel Despland's statement "the organization of the State is a sign of moral progress, not of moral decadence" (34) recorded one view of the immediate effect of the governmental effectiveness after the Treaty of Westphalia. Immanuel Kant formulated definite perspectives on peace that applied to an investigation of the development of the concept of peace. He saw two different paths to peace, leading to two different kinds of peace, a durable peace and a perfect peace. The durable peace appeared throughout history and especially could be applied to the long-term effects of the Westphalia period and Versailles (1919) in the short term, even though in 2006 there are still ramifications from the effects of Versailles, especially in Iraq. Kant's two paths to peace came through the legal process and the moral process. The legal process brought the durable peace, which resulted from armistices that produced holding patterns after conflicts. Armistices protected the interests of the people who made them, people with a great deal of will. The moral process required the self-discipline of the people involved and may have included constraints. This process led to a perfect peace (Despland 34-35). Writing about Kant's 
"Idea for a Universal History from the Cosmopolitan Point of View," Despland continued to suggest in the light of the perfect peace that Kant's view was that "man, being free, must be the cause of his own cultural development. The main task of [Kant's] essay is to establish the links and distinctions between the end pursued by Nature-the development of all natural capacities of man-and the fact that men choose the ends they set before themselves" (22).

When considering Kant as well as his predecessor, Grotius, one may see they both shared the idea that peace was the concern, at least, in the background and the intent of the events of history. According to Carl J. Freidrich, Kant's work on peace was the ultimate understandable goal of everything Kant wrote. The important principles of Kant's Idea included the following principles, which echoed some of the language and concepts in Hobbes, Locke, and Rousseau. The cultural dialogue established in the aftermath of Westphalia continues to compel thinking through the $20^{\text {th }}$ century. For Kant, in his "Idea for a Universal History from the Cosmopolitan Point of View,"

1. Reason guided the formation of laws, because human nature worked according to its end (118). The laws provided the constraints that qualified the personal freedoms of the populace, but in Rousseau's estimation allowed for greater individual freedom within the confines of the social order.

2. Reason was "fully developed in the species, not in the individual." The natural instinct of an individual had its limits, but the accumulation of these instincts from individual to individual did not. Through trial and error in the individual the species progressed from "one level of understanding to the next" (118). 
3. Man secured his own happiness "by his own reason and free of instinct.... Nature gave man reason and the freedom of will which rests upon reason." Man's developmental arc ran from an animal weakness through "great skills, to inner perfection of mind, and to blessed happiness" (119). Later generations always reaped the benefit of their labors, some of which brought an end to war and freed the culture to address the needs of the mind. Tranquility remained an important aspect of the development of the concept of peace.

4. There was a contradiction in man between sociability needs and an asociability. "Culture actually consists in the social value of man" (120). It took man's effort to raise himself from his own indolence to develop his own natural faculties, which includes the ability to develop the concept of peace.

5. "A completely just civic constitution is the highest task nature has set mankind" (121). Under such an arrangement, man could "achieve the supreme objective of nature, the development of all the faculties of man by his own effort" (121). The highest purpose of nature was for man to secure those ends to develop the freedom of his society so that it would "coexist with the freedom of other societies" (122). Natural Law connected with Right Reason.

6. Man needed a master who could lead him to act according to a will applicable to the general species. The problem was that all men needed masters, so one master needed another above him. Yet, the master at the top needed to be "just in himself and yet a man" (123). But, at that level, governing principles in man should have been right conceptions, great experience, and a good will. Such conceptions were not all easy to come by. 
7. The "perfect civic constitution depends upon the problem of a lawful external relationship of the states and cannot be solved without the latter" (123). This state of affairs became important after the Treaty of Westphalia. It operated before the early Modern era in the commune of Siena, for example, even if Siena did not operate in relation to a state, but rather somewhat in conflict with other rival towns and cities that operated as if they were states in a classical or early-Renaissance sense. Ideally a state of affairs could create a civic commonwealth that was able to "maintain itself automatically" (125).

8. History was viewed as the realization to bring about a perfect constitution. What happened repeatedly was that "the great societies and states" in their avowed desire for peace ended up mired in preparations for war and brought about the very conditions of war from which they were trying to protect themselves. They had the ability to use their protection offensively instead of spending their energies "leav[ing] the lawless state of savages and to enter[ing] into a union of nations wherein each, even the smallest state, could expect to derive its security and rights... only from this great union of nations" (124)

9. It was possible "to write a general world history" that articulated "a perfect civic association of mankind" (129). Here Kant meant philosophical history. "The freedom of the Will in metaphysics, the phenomenal appearance of the will, i.e., human actions, are determined by general laws of nature like any other event in nature." The individual was the representation of development of the species, the mark of the evolution of the species. The events of an 
individual life may have seemed to proceed according to no plan, but if one tracked all individual lives, the events seemed to occur "according to stable natural laws" (116). It was the philosopher who detected and articulated the plan, "to discover an end of nature in this senseless march of human events" (117).

Natural Law was a common idea among the European thinkers and treatise writers that enabled the development of the concept of peace to continue after the Thirty Years' War ended. Kant's thinking encompassed a wide range of applications including the arts and fit right in with Peter Paul Rubens' notion of war as a time that cancels education and the arts. Paul Oppenheimer in his portrait of Rubens wrote "the geyser of hysteria unleashed by human carnage, that ghastly paradox of officially sponsored slaughter in which psychosis is accepted as normality, disease as health and evil itself as a monstrous virtue" (338). Rubens himself put the cancellation in this way. The "fecundity, procreation, and charity are thwarted by War, which corrupts and destroys everything.... Mars...treads underfoot all the arts and letters" (Magurn 409). The consideration of the effect war had on the inner life of the socio-political scene provided a psychological insight into the interaction between governance and the governed, an interaction that in the early-Modern era was beginning to be expressed.

We are highly civilized by art and science, we are civilized in all kinds of social graces and decency to the point where it becomes exasperating, but much (must be discarded) before we can consider ourselves truly ethicized...something similar to ethics in the form of a love of honor and external decency (which) constitutes civilization.... States use their resources for their vain and violent designs for expansion; slow efforts toward the inner shaping of the minds of their citizens... (Kant 126). 
As Arnold Hauser thought, if "artistic creation proceeds from practical objectives and social institutions" (Sociology of Art 26), the culture's undercurrents and points of view in the Westphalia period would represent themselves through artistic expressions before they reveal themselves through official political events or policy. The Westphalia period differed from the other historical periods surveyed in this dissertation. With a change in the structure of Europe during this period and the emergence of the perspectives of the members of the populace beginning to shape the growth of the concept of peace, artistic expressions conveyed information about the big issues of western culture before they surfaced politically. For instance, in paintings Rubens created before the years of the Treaty of Westphalia, viewers could see a clear dissatisfaction on behalf of the populace with the experience of the Thirty Years' War. By the time the Treaty finally ended the war, the visible devastation equated to the spiritual annihilation Rubens had already depicted in his painting, The Horrors of War. In the period following the Treaty, more perspectives from authors Thomas Hobbes, John Locke, and JeanJacques Rousseau, to name three writers whose work and political thinking Hugo Grotius anticipated before the end of the Thirty Years' War, emerged in the literature of the times to suggest methods of political and emotional organization for the new societies that were able to establish themselves together in the wake of the influence of the Treaty.

During the Westphalia period individual thinkers addressed the concept of peace before the states attempted to appropriate the concept. In this period the west witnessed the beginnings of the enduring voice of the populace coupled with the advance of printing, which made the thinkers' ideas easy to distribute widely. The writers could maintain their thinking and spread it throughout the culture where their thinking would 
exert its influence. Well in the wake of the influential post-Westphalia-period thinkers, Immanuel Kant, for example, wrote of the idea of perpetual peace and recognized as did many that peace was wrapped up in the Modern desire to rethink the ideas of laws, human rights, and the responsibilities of the state.

If it is a duty to realize a state of public law, and if at the same time there is a well-grounded hope of its being realized-although it may only be by approximation to it that advances ad infinitum - then perpetual peace is a fact that is destined historically to follow the falsely so-called treaties of peace which have been but cessations of hostilities. Perpetual peace is, therefore, no empty idea, but a practical thing which, through its gradual solution, is coming always nearer its final realization; and it may well be hoped that progress toward it will be made at more rapid rates of advance in the times to come (Kant 127).

It was convenient to view this period as a collective period when artistic points of view and social commentary were covering similar concerns. Collective periods, such as this one, were periods when the concept of peace came up for air. As long as the collective socio-political framework built itself well and succeeded, the peace would not fail. Perhaps one original reason for the collective in this period was that in 1648, the state of Europe and England was a mess. Norman Davies writes of a "concatenation of catastrophes" that led to a "general seventeenth-century crisis." He suggests there was a coincidence of occurrences bringing about this state. On the one hand, there may have been a Modern crisis where the center of the political spectrum felt reactions from both sides. The "growing pains of all-European capitalism" affected Europe (Davies 569). The Modern period, though, began at this point. Germany's misery informed two periods of deep European crisis, one of which provided the background to Westphalia. The Thirty Years War sowed the seeds of German fracturing. The other informed the $20^{\text {th }}$ century and saw Germany's misery return after the Treaty of Versailles. 
When one reads the Treaty of Westphalia, as suggests Helga Zepp-LaRouche, certain articles stand out as radically different conceptually from any imaginable document that might appear in the west in the late-Modern era.

In the name of the most holy and individual Trinity: Be it known to all, and every one whom it may concern, or to whom in any manner it may belong, That for many Years past, Discords and Civil Divisions being stir'd up in the Roman Empire, which increas'd to such a degree, that not only all Germany, but also the neighbouring Kingdoms, and France particularly, have been involv'd in the Disorders of a long and cruel War...It has at last happen'd, by the effect of Divine Goodness, seconded by the Endeavours of the most Serene Republick of Venice, who in this sad time, when all Christendom is imbroil'd, has not ceas'd to contribute its Counsels for the publick Welfare and Tranquillity; so that on th[is] side, and the other, they have form'd Thoughts of an universal Peace (Preamble).

There were comparisons between the Language of the Treaty and the Language of Political Thought after 1648 . The language from the treaty echoed throughout various treatises written by political thinkers, Hobbes, Locke, and Rousseau, after the signing and publication of the Treaty of Westphalia. The language of the Treaty of Westphalia declares the emotional path to peace. Europe was essentially a newborn institution finding its way as a concatenation of nations with powerful resources and untested national wills collected in the attempt to avoid wars. Western culture faced in this period a bona-fide paradigm shift of the kind Thomas Kuhn would later write about in the early $1960 \mathrm{~s}$.

The Treaty minimized religious and imperial powers in favor of the order of nations. There were new alignments of concentrated power, for example, in Austria and Bavaria. The smaller sees, such as, "the Confession of Augsburg, and particularly the Inhabitants of Oppenheim" were again restored to their churches as they had them in 
1624 (Article XXVIII). Religious toleration grew. The Treaty sought to restore order after the granting of lands to Sweden and France. Article XLVII, though, provided an explanation for the omission of a "general Restitution [for] things which cannot be restor'd," such as, "things destroy'd, ruin'd, and converted to other uses for the publick Security." Article CXXIII established the code for such treaties in a Modern sense. "That nevertheless the concluded Peace shall remain in force, and all Partys in this Transaction shall be oblig'd to defend and protect all and every Article of this Peace against any one, without distinction of Religion...."

According to Helga Zepp-LaRouche in her address, "A Precedent for Peace in the Balkans: The Peace of Westphalia," delivered to the EIR Seminar, 5 May 1999, the gist of the Peace of Westphalia was that it opened Europe up to the forgiveness of hostilities, debts, and a vision of mankind in the ideal sense. The post-Treaty political writers (Hobbes, Locke, Rousseau) echoed this cultural change and contributed to it. By World War I and II in the $20^{\text {th }}$ century all this was lost to reparations and quid-pro-quo agreements at Versailles. She said,

The Peace of Westphalia, when all the war parties came together, was the first time that a European community of sovereign states was established. And it was only possible because all of its members recognized each other as having equal legal standing, and guaranteed each other their independence. They had to recognize their international legal treaties as binding, if they wanted to be an international community of law (paragraph 6).

Readers may comprehend this when reading The Treaty itself, Article Two specifically.

That there shall be on the one side and the other a perpetual Oblivion, Amnesty, or Pardon of all that has been committed since the beginning of these Troubles, in what place, or what manner soever the Hostilitys have been practis'd, in such a manner, that no body, under any pretext whatsoever, shall practice any Acts of Hostility, entertain any Enmity, or cause any Trouble to each other; neither as to Persons, Effects and Securitys, neither of themselves or by others, neither privately nor openly, neither directly nor indirectly, neither under the colour of 
Right, nor by the way of Deed, either within or without the extent of the Empire, notwithstanding all Covenants made before to the contrary: That they shall not act, or permit to be acted, any wrong or injury to any whatsoever; but that all that has pass'd on the one side, and the other, as well before as during the War, in Words, Writings, and Outrageous Actions, in Violences, Hostilitys, Damages and Expences, without any respect to Persons or Things, shall be entirely abolish'd in such a manner that all that might be demanded of, or pretended to, by each other on that behalf, shall be bury'd in eternal Oblivion.

The Peace of Westphalia admitted into the character of the newly established European political system an Ideal, every bit as strong as any Platonic Ideal. However, this one sought to be applied in a realistic sense to guide relationships on the ground among the new nations of Europe. Rather than direct the minutiae of lingering animosities leftover from the years of war, the Treaty established a point of view that opened Europe to repairing the humanitarian relations among nations in a way that never has happened since. Zepp-LaRouche said astutely that "most important [in the Treaty], was the idea that the raison d'être - the reason for its existence, the identity of this new alliance-of this community of states, could never be only its self-preservation. It would be morally justified only if it realized ideas and principles which had a higher unifying purpose than just the states themselves" (paragraph 7). On this footing began the earlyModern era, because Europe embraced a spirit of forgiveness recognizing the essential nature of the need for all the nations to view themselves united in a fundamental way. The development of the concept of peace in the west resumed at this point after the long wars. As the decades passed, though, the difficulties of holding together this union become difficult to maintain. Eventually Europe found the will, but only after costing itself and its populations. Zepp-LaRouche noticed the parallels between the Westphalia Ideal and "the idea of John Quincy Adams, that the United States must work toward fostering a community of principle among nations of the world." She posited the Peace of 
Westphalia as "probably the most important predecessor of [Adams'] idea" (paragraph

8). Interestingly over the centuries the United States, made up of many émigrés from

Europe, established the idea into successful practice away from the bloodied earth of Europe.

In the new nation system, ideas of sovereignty and how the populace fit sociopolitically became the focus of political thinking over a great number of years. The language of the Treaty of Westphalia promoted the concept of peace as the most important quality of life among nations. Perhaps the will of the populations-the popular voice-of many of the nations influenced the writing of the Treaty. In one sense, the voice of the populace came through in the creation of artistic images before the Treaty was even begun. The Rubens painting, The Horrors of War, provided one example how the populace, living under the sway of this type of horrific existence, was made to suffer excruciatingly. In literary works written after the end of the war, the echoes of the gist of the Treaty appear in political treatises by Hobbes, Locke, and later, Rousseau. The ideas espoused by these writers become more democratic as they developed one after another. Yet, all, both artistic and literary, were creations made in the spirit of the desire for peace. There was an "analogy [in cultural expression] between art and language [as] one of the most revealing parallelisms....as far as the relationship of spontaneous to conventional means of expression is concerned" (Hauser 43).

E. H. Gombrich wrote of paintings and their purposes that "light [is]...strongest in area of principle viewpoint" (126). This statement applied to the Allegory of Good Government from the early-Renaissance period in Siena in that the light shines strongest 
on the figure of Peace. Gombrich's statement also applied to Rubens Horrors of War in which the light shone on the travail of Europa, including on Venus and the backs of the trampled. (See Figure 4.) The women of Rubens struck their contemporary viewer with particular force. Robert Hughes wrote, "when discussing the work of a painter like Rubens, who used the common symbolic currency of his time with an uncommon subtlety and power," (165) the viewer appreciated the despair in the popular experience.

A. F. Pollard posited the question when do peasants revolt? (119). The answer was out of hope not despair. Rubens presented in his painting an allegorical scene that was easy for his viewers to reckon as a desperate image, but if one followed Pollard's question and realized that Rubens painted ten years before the Treaty of Westphalia, one may read this painting as a thesis expressing hope. L. Rosenthal viewed Rubens' depiction of Mars in this light, Alecto being an enabler of Mars. "In taking up arms Mars protects himself against feminine sexual desire, discovering in his warrior identity a means of escaping, of not having to submit to the power of love" (104). The power of love was strong and would eventually conquer the force of war, enabling the concept of peace to re-emerge sanctioned by the Treaty of Westphalia.

One may declare that the painting by Rubens was emblematic of the spirit of the Westphalia period before it was even named. This painting, to use the terminology of Heinrich Wölfflin in his Principles of Art History, offered a scene presented in a painterly mode where figures signified meanings because other figures appeared in juxtaposition with them. The individual figures would not necessarily convey all their meaning in isolation. The painting used light and shadow as strategic elements that enhanced the meaning of the entire scene. And just as there was movement in the undercurrents of the 
period's socio-political order leading up to the drafting of the Treaty of Westphalia, the voicings of the desires of the populace to end the war was an urgent desire full of movement. When compared to the linear mode of presentation in the Lorenzetti frescoes in Siena where the figures in the Allegory of Good Government, for example, were arranged in a line with no one aspect of a figure serving to elucidate another's, Rubens painted in a more painterly mode where the individual figures and elements of his paintings were not as important singly as was the meaning he imparted to the entire image in his placement of the individual figures. The Lorenzetti frescoes in the Palazzo Pubblico in Siena, especially the Allegory of Good Government, had been composed of figures and shapes represented individually in focus as individual parts, which then added up to form a visual catalogue of sorts whose additive impact expressed linear relations among the figures and shapes in the frescoes. In the early Modern era, the evocation of meaning in painting required different approaches than did painting in the early Renaissance. All the parts of the Horrors of War by contrast to the parts of the Lorenzetti frescoes related to each other in combination, establishing together the larger meaning of the entire painting. It was more difficult to single out individual figures as equivalents to each other in order to accumulate an interpretation of meaning for the entire painting. The individual elements in the fresco did not bear in the "marrow of their bones" the sense of the entire picture, as if in microcosm to the entire picture. They merely fit into the whole. However, in the Rubens painting, the individual elements, including the lighting, served the larger order of the whole.

Rubens in one single image showed his viewers the state of Europe and what she lacked, the concept of peace, which allowed the free play of the activities of the mind. 
The viewer of Rubens' painting could see strewn on the floor underfoot, representations of the arts, the knowledge of the world. Thomas Hobbes came along after the Treaty and provided one voice that addressed the definition of peace, which had two focal points.

One was for grand peace for the entire continent or the spiritual dimension of peace. The other was for personal peace. The painting, The Horrors of War, presented an allegory, so its location was abstract, but definitely on the cultural stage. Rubens himself described much of the painting himself in a letter he wrote to Justus Sustermans in Antwerp on 12 March 1638. From the left of the painting all the evils spilled forth as a result of the image of the doors to the Temple of Janus being opened to signify a state of War operating in the west. The central figure of War trampled all the arts represented under the foot of Mars by papers, music, and the arrows of Cupid. Meanwhile Venus tried to hold him back with her charms while her small cupids reacted to her efforts. The Fury Alecto enabled Mars even though Mars seemed to want to avoid Venus. For the first time, Europa, to the left of Venus, arms raised in despair over what she had lost repeatedly, was depicted with a tale to tell, woes to show, rather than as in the fresco in Siena, a town with little reach, which was similar to other towns (Magurn 408-409). Europe came together later as a continent and, as such, was unique in her aspirations and hopes as well as her despair. Heinrich Wölfflin noted what the stylistic differences alone communicated about differences in world perspectives. There were differences in messages as well as differences in the way historical periods developed the concept of peace. But, like a whole with many parts, the culture's aspects were expressed essentially when the parts expressed themselves.

The great contrast between linear and painterly style corresponds to radically different interests in the world. In the former case, it is the solid figure, in the 
latter, the changing appearance: in the former, the enduring form, measurable, finite; in the latter, the movement, the form in function; in the former, the thing in itself; in the latter, the thing in its relations. And if we can say that in the linear style the hand has felt out the corporeal world essentially according to its plastic content, the eye in the painterly stage has become sensitive to the most various textures, and it is no contradiction if even here the visual sense seems nourished by the tactile sense - that other tactile sense which relishes the kind of surface, the different skin of things. Sensation now penetrates beyond the solid object into the realm of the immaterial. The painterly style alone knows a beauty of the incorporeal. From differently oriented interests in the world, each time a new beauty comes to birth (27).

The passage suggested the kind of shift that took place when the Treaty of Westphalia was enacted. In the linear vision in art, "the sense and beauty of things is first sought in the outline" (Wölfflin 18). While viewing the Lorenzetti Allegory of Good Government, the eye built its awareness of outlines separate from one another and in combination as figures that added up consciously to make a total painting that conveyed accumulative information. Then, when viewing a painting such as The Horrors of War, one comprehended the sense of the painting emerging from the shapes in the way they merged into one complex mass of information, one meaning interdependent from another to form a complete statement of emotional or intellectual significance. In the Sienese fresco, the image of Peace suggested a move to the painterly only insofar as Lorenzetti had rendered her shape to suggest a three-dimensionality he did not impart to the other shapes. Peace would spread into a realm of influence that overcame other twodimensional boundaries in the Rubens painting and soon within the culture. In the Sienese fresco, "stress is laid on the limits of things"; in the Rubens, the "apprehension of the world [is] a shifting semblance" (Wölfflin 14). In the fresco all the parts of the image equally supported the whole. In Rubens, the parts supported the theme expressed in the painting. The will of the people began to show through in art before the end of the Thirty 
Years' War. In fact, Rubens' painting, The Horrors of War, suggested a deep desire to promote the idea that Europe was suffering from extended wars too deeply to bear.

L. Rosenthal, writing in the Oxford Art Journal in 1993, noticed important qualities in the painting and Rubens' ability to bring them out. The artist expressed the ideals of the society, which underscored the notion that he expressed social undercurrents of the time and particularly populist ones. Rubens was able on the one hand to create persuasive allegories that "served...many patrons, including several European courts and the Counter-Reformation Catholic Church" (92) as well as linking basic sexual and political themes of the time (103). Both male and female shapes in the painting represented abstractions that communicated to the patrons of his time (92). Rosenthal connected the opportunities Rubens had for comprehension of his socio-political realm with his abilities to embrace and utilize basic human urges to get across his point.

Rubens was a man deeply aware of and active in the politics of his age, a politics dominated in Flanders by The Netherlands' revolt against Spanish rule and the Thirty Years' War abroad... His involvement in efforts to restore a permanent peace to the region engaged him in essential, though unofficial, diplomatic work in the 1620s for Archduke Albert and Infant Isabella, the Hapsburg regents in Flanders to whom Rubens was appointed court painter in 1609. But at the same time that he was involved in the delicate and complex world of political negotiation and international strategy he produced a series of paintings on the subject of war and peace in which erotic relations rather than court diplomacy and economic and religious strife are presented as the crux of the matter... Ideal manhood and ideal statehood, dually invoked by the display of his armed might, seem to both have something to do with an attitude toward women and sexuality as well (103).

Robert Hughes underscored the importance of rhetoric to a thorough understanding of this age and how rhetorical qualities even cropped up in a comprehension of this particular Rubens painting. Hughes found the devices Rubens employs to be "almost comparable to the tropes of rhetorical theory" (157-8). He 
suggested something similar to synecdoche was at work in the figure of the Fury, Alecto. She was a natural symbol, rather than a direct one as in Justice with a scales and sword. Her role was "defined by the narrative, not by dress or attribute. Her anonymity guarantees her a measure of dramatic pathos and enables Rubens to concentrate a number of meanings within a single figure" (158). As such this figure, as well as the one of Mars and wailing Europa, became painterly because of their dependence on the scene, which of course included them. They depended on each other for their meaning. Alone they would offer unfulfilled meaning.

For the first time and emblematic of the period, Rubens depicted Europa with a tale to tell, woes to show, rather than similar to Siena, a town with little reach. Rubens' voluptuous figures became landscapes of sorts, especially when aware viewers noticed the fact of distance in the painting. The scene was an interior one, but interior in the sense that these horrors, which have a distinctly mythological and psychological character shielded the topography suggested there in depth if one could focus one's attention. Topography became physical and personal, but still general and distant in service to a society. Rubens had introduced it into this scene to remind his viewers their focus had further directions, the outside, which corresponded to the unknown relation to an existing chaos of governing that $21^{\mathrm{st}}$-century historians know to be what came in advance of a new alignment of nations created by the Treaty. 'The people affected were represented humanly in the painting, Europa and Venus. All others were mythological. In Heinrich Wölfflin's terms, when compared to the linearity of the Lorenzetti frescoes, Ruben's art was more baroque, more painterly because the baroque in The Horrors of War was a perception. Rubens had provided a perception of the experience of the populace who 
suffered during the Thirty Years' War. What appeared on the surface was not literally, but culturally meaningful.

After the Treaty of Westphalia was signed and the essential machinery of the peace had been articulated, political writers at different times expressed their ideas of socio-political structures in rhetoric and ideals similar to the thrust of the language espoused in the Treaty itself. The post-Westphalia period opened up a dialogue of thought as if it were itself the personality of the era. Thomas Hobbes wrote a conservative treatise in The Leviathan that sought to determine the place in the structuring of the new social order for human nature to address itself. John Locke built on these ideas but did so with a degree of influence from periods well into the western cultural past. Jean-Jacques Rousseau, a true continental, captured a voice whose style recurred continuously into the late Modern period in various writing genres, including autobiography and fiction. His style conveyed a line of thought that remains Modern in feel through the mid- $20^{\text {th }}$ century.

\section{Hobbes}

With Thomas Hobbes the dialogue began among these writers concerning the relationships of the populace to its sovereigns, the populace to itself, and the actual definitions of war and peace. He wrote about Man followed by writing about the Commonwealth, which he called the "artificial man." Hobbes' perspective identified the Commonwealth, more or less a living organism, in an interesting light. Chapter II in The Leviathan ostensibly spoke to the subject of imagination in man, yet some of its text could be applied in a sense to both the individual and the Commonwealth itself as a 
macrocosmic representation of the individual. The concept of peace had laid still in the west as would a "thing [that] unless somewhat else stir it, it will lie still forever" (II, 1). Here Hobbes wrote of the imagination of man; however, in this instance and given the time in which he writes, the same could be written of the concept of peace. The Treaty of Westphalia had disturbed the dormant concept of peace, waking it. Just as men measure "all other things, by themselves," the concept of peace measured itself by its relation to war. In this period the peace and the war were closely linked. Understandably the culture measured the peace in contrast. Hobbes's comments on imagination and movement applied to "a body... once in motion... [that] moveth...eternally; and whatsoever hindreth it, cannot in an instant, but in time, and by degrees extinguish it" (II, 2), which applied to the effect the concept of peace will have on the war that had recently ended in Europe. The effect was that the peace succeeded. As Hobbes described the mind as a seeking entity, he gave a clue to the activity of the culture, which was also such an entity. It sought peace after the cataclysm of the wars.

Hobbes offered a considered discussion of what made the body politic a balanced entity. In his section on the Commonwealth, Chapter 18, part 13, he wrote about the need for "laws of honour," but attributed the responsibilities of honour to the sovereign. The language of the Treaty of Westphalia had addressed the sense of the need for honour. The Treaty introduced the notion of forgiveness for eternity for the responsibilities for the lengthy wars. Honour was one of the qualities of an organism or an organism's behavior that produced a strong characteristic, such as, trust only, which was a quality inherent in the concept of peace. Otherwise, the characteristic, Hobbes noted, produced infirmities or 
weaknesses. He did not attribute "honour" to the populace, which had not had the chance to need to exercise the trait.

As Hobbes developed his treatise, he came to the notions of human nature, sovereignty, liberty, and self-preservation. J. C. A. Gaskin writes of The Leviathan, that Hobbes's expression of the state of war is like "a miserable conflict of isolated individuals, each taking what he can get." Since human nature for Hobbes generally associated itself with self-preservation as the true meaning of liberty (XIV, 1), he began with the notion that an individual's desires drove him to do good, but unchecked he rarely focused that urge to do good altruistically. The aggregation of individuals choosing to do good for themselves was what leads to a state of war. Such was the liberty of individuals, which ultimately in the state caused conflicts. The Treaty of Westphalia corresponded neatly with some of the ideas Hobbes expressed because the Treaty's verbiage suggests an undoing, forestalling, or cessation of such drives in humanity among the nations of Europe.

...because the state of war is a state of perpetual fear and death and lesser evils. It is the greatest calamity that can happen in this life, and 'reason suggesteth convenient articles of peace, upon which men may be drawn to agreement... otherwise...called laws of nature' (Gaskin introducing Leviathan XIII, 14. xxxii).

According to Gaskin, the Laws of Nature for Hobbes were "totally man-centered" (xxxii), but for the time they were the laws for peace. For them to work, the society, which was composed of individuals, must have been willing to follow the same laws. Hobbes wrote that "every man, ought to endeavor peace, as far as he has hope of obtaining it," then stated what for him is the reason for war, "when he cannot obtain it, that he may seek, and use, all helps, and advantages of war" (XIV, 4). For Hobbes, such 
was the fundamental law of nature, which addressed directly the natural human urge to seek peace and war. Each provided a qualified aim, but he seemed to favor the second part of the law, the one leading to war. Man required a great deal of effort to avoid the drive to war. But, at the time, in the light of decades of recent events on the continent of Europe, Hobbes gleaned that the tendency of human nature had been to lead itself to war for reasons of desire over altruism. Hobbes established his fundamental laws of nature in the form of a contract, which took into account how an individual divested himself of his liberty in exchange for another thing or the promise of another thing. In Chapter XV of The Leviathan, he discussed Justice as well as an aspect of the laws of nature, the contract, which he called "covenant" when he wrote "when a covenant is made, then to break it is unjust" $(\mathrm{XV}, 2)$. These were the laws that if men honored them would help them maintain peace and avoid the state of war.

According to Hobbes' thinking, peace in the individual led to peace in the state if the individual comprehended that by giving up some of his liberty, his desire, that he granted to himself and to the society he contracts with more liberty in the long run. "This is more than consent, or concord; it is a real unity of them all, in one and the same person, made by covenant of every man with every man." One man gave up his right of selfgoverning to another and expected other men to do likewise. "This done, the multitude so united in one person, is called a commonwealth.... This is the generation of that great Leviathan, or rather of the Mortal God... to which we owe our peace and defence" (XVII, 13). Thus, guarantees of "peace at home" and "mutual aid [to] enemies abroad," which does not only guarantee peace, instead guaranteed nationhood.

...to confer all their power and strength upon one man, or upon one assembly of men, that may reduce all their wills, by a plurality of voices, unto one will...to 
bear their person; and to every one to own, and acknowledge himself to be author of whatsoever he that so beareth their person, shall act, or cause to be acted, in those things that concern the common peace and safety... (XVII 13).

The difference post-Westphalia was that the reason behind the structure of the Commonwealth from the individual to the collective and the establishment of the sovereign, even in some cases the monarch, was Right Reason. All individuals partook of it and were capable of understanding and accepting it. The west in the Westphalia period differed from the early-Renaissance period when the ruling powers spoke univocally. The multi-vocality in the Westphalia period arose as a characteristic of post-Westphalia governance in the west and the emergence of the voice of the populace. The multivocality remained as a characteristic of western cultural expression.

In De Cive, 1642, Hobbes addressed many of the issues also included in Leviathan, and like Rubens offered his own ideas before the governing powers and armies who were capable of listening. There was a significant difference between wartime and peacetime. War stifled the culture's ability to advance. Both Hobbes and Rubens recognized the debilitating effect war had on education and the arts. But, Hobbes expressed this judgment in a specific way. For him the quality of time during a Peace was useful and expanded Marsilius' notion of tranquility from the Defensor Pacis. Hobbes' writing in The Leviathan, published in 1651, having occurred just after the signing of the Treaty of Westphalia anticipated a psychological understanding of the individual in relation to the Commonwealth and the sovereign that advanced collective thinking from earlier ages. More than likely, Hobbes contributed to the beginnings of such thinking. One may posit Hobbes' introduction of two kinds of time as qualities of the concept of peace and the experience of war. The quality of time in War included almost a holding- 
in-abeyance of the ability for an individual to progress and by extension the Commonwealth, too. With so much war in the culture preceding the end of the Thirty Years' War, the west had to cope with enduring a state of affairs unlike the type to which the west was accustomed. In other words, war was the state the continent knew. The Treaty of Westphalia by seeking to forego blame and establish nations as collective structures to promote peace, re-created the concept of peace itself. The disposition to war Hobbes understood as creating a byproduct one could call Wartime, which existed even when armies fought no battles. Wartime was active when the culture's disposition was to be ready for battle as a solution to troubles. The holding-pattern nature of wartime in general precluded the natural advance of human knowledge and expression. And, this shortfall of progression would include education, science, and the arts. The quality of time during the peace, which was again new to the west, was useful in allowing the culture intellectually and socio-politically to exercise its thought in order to benefit the culture. The individuals who made up the general populace, the sovereigns who guided them, and the nations that collected them were theoretically composites of the sociopolitical organism throughout the west. Peacetime offered the ability and desire to examine socio-political structures. By the time of the Romantic poets, this cultural ability and benefit of the concept of peace was becoming a cultural point of view, expressed by Wordsworth in his notion of recollection in tranquility.

Hobbes wrote about judgment of peace and security and defense by the sovereign (XVIII, 8). These thoughts maintained the same focus as those of the individual did, where the condition of mankind was to recognize "reason suggesteth convenient articles of peace, upon which men may be drawn to agreement" (XIII, 14). For Hobbes the 
agreements were the Laws of Nature. The first law was "for the preservation of his own nature" (XIV, 1) and the second which spelled out "the absence of external impediments... [that often took] away part of man's power to do what he wanted" (XIV 2). On a broader level, the individual under auspices of the sovereign could place his faith in this aspect of the commonwealth. The fundamental laws of nature included "the first branch of which rule... which is, to seek peace, and follow it. The second, the sum of the right of nature; which is, by all means we can, to defend ourselves" (XIV, 4). The development of the concept of peace required a defense against the desire to let events escalate to war. For this eventuality, Hobbes noted the need for mediators. In another passage, Hobbes anticipated thinking that reached into the activities of the $20^{\text {th }}$-century United Nations when he wrote about "safe conduct." The mediators of peace need safe conduct. "For the law that commandeth peace, as the end, commandeth intercession, as the means, and to intercession the means is safe conduct" (XV, 29).

The Europe of nations for the next 300 years, even when wars recurred, still saw some of its tenets finally being achieved by the 1950s. Even by 2000 and beyond with the European Union, it seemed in the post-WWII Europe that "safe conduct" may have been achieved in the fact of the decrease in nationalism and the structure of both the United Nations and the European Union itself. The duration in peacetime allowed for achievements that war had trampled in the dust as is so visible in Rubens', The Horrors of War.

\section{Locke}

After Hobbes, John Locke wrote later in the "Second Treatise" of his Two Treatises of Government, 
political power, then, I take to be a right of making laws with penalties of death and consequently all less penalties, for the regulating and preserving of property, and of employing the force of the community, in the execution of such laws, and in the defence of the commonwealth from foreign injury; and all this only for the public good" (Chapter I, 3).

Locke changed the dialogic equation a bit from Hobbes. He did not focus as much on the concept of the sovereign. Instead, he seemed to regard that which addressed the more general need and practice of a Modern society, which by 1680 had come to the mind of many socio-political thinkers. For Locke, there were two states of nature. The ideal state, not easily realized, allowed for "men living together according to reason, without a common superior on earth, with authority to judge between them, is properly the state of nature." On the other hand, equally probable to occur, "want of a common judge with authority puts all men in a state of nature: force without right, upon a man's person, makes a state of war, both where there is, and is not, a common judge" (Chapter 3, 19). Locke concluded, "but though men, when they enter into society, give up the equality, liberty, and executive power they had in the state of nature, into the hands of the society, to be so far disposed of the legislative as the food of the society shall require...all this to be directed to no other end but the peace, safety, and public good of the people" (Chapter 9, 131). Locke differed from Hobbes, who would "force men to be rational" in favor of viewing society in the light of individuals who responded to the situation of government by consent (Shapiro, 323). Locke recognized what individuals gave up in order to make the socio-political order function. At this point, Hobbes and Locke provided related aspects of socio-political thinking with both points of view still related to each other. The culture was still operating in the throes of a blameless aftermath of war. 


\section{Rousseau}

Rousseauvian thinking differed from that of both Hobbes and Locke. Rousseau was born in 1712 well after the Westphalia period, but wrote completely under its influence. Plus, he was European, rather than English. The Thirty Years' War was fought on the European soil from which Rousseau sprang. "Born as I was the citizen of a free state and a member of its sovereign body..." (Social Contract 49) wrote Rousseau. By virtue of his statement, he indicated how natural he felt with the complexities of similarity and dichotomy Hobbes and Locke discussed between the individual and the Commonwealth. To digest the meaning of the Treaty of Westphalia, Rousseau did not have to live through those shifts brought on by the necessity for the social order.

Reading Rousseau in comparison to Hobbes and Locke, one can comprehend an evolved direction in culture. "Rousseau not only rejects Hobbes's [implied] claim that men must choose between being free and being ruled, he positively asserts that it is only through living in civil society that men can experience their fullest freedom. [For Rousseau] this is the connection between freedom and virtue" (Cranston 28). Virtue conceptually and as a term, of course, has Roman echoes. The sense one received was that the social order in some new way was coalescing around its strengths. For Hobbes and Locke, one sensed that they had to conceptualize their ideas with such rigor and so carefully in order either to guide the socio-political order or simply to help the order digest the effects of the Treaty of Westphalia and the wars that preceded it. Rousseau in another work "stresses both the freedom and the innocence of man in the state of nature" (28), which was not as problematic for him as it was for the English thinkers.

Additionally Rousseau established a new lens with his viewpoint through which 
contemporary readers may contrast his period again with the Sienese. There was no sense of innocence portrayed in the Lorenzetti fresco, Good Government in the Country. The early-Renaissance west had not established that judgment as a valid or defining one in the culture. But, for Hobbes, man-in-nature was "aggressive and rapacious." For Rousseau, man was "stupid and unimaginative." Only in political society was he intelligent (28).

For Rousseau in the Social Contract as well as in the Confessions, "men are happy in the state of nature" (Cranston 29). Virtue for him related to morality, which qualified virtue a shade differently than in the age of Rome. Still, though, "[Rousseau] is saying that the state of nature is man's original state, not his natural state; for man can only realize his full nature as a man by making the social compact and living under law" (29). Rousseau, as did Hobbes and Locke, discussed the fact that men should rule themselves. For him, men had the obligation, but it did not bind them. "Rousseau is original in holding that no such transfer of sovereignty need or should take place: sovereignty not only originates in people; it ought to stay there" $(30)$. In the $20^{\text {th }}$ century, peace movements among other movements used such a concept to gain the authority they needed among their adherents to make strong and effective organizations. Duane L. Cady has expressed a similar thought. "The goal is a world of people and nations in control of themselves" (79).

The culture established from Hobbes through Rousseau the parameters for the expression of the populace, one with the other, one building an argument, then another responding to it. In the long run, the dialogical give-and-take formed the viewpoint the culture used. The result was similar to the immediate aftereffects of Westphalia and nationalism. By the time the $20^{\text {th }}$ century arrived, there had been a recurrence of 
nationalist trouble again, especially after 1871 . In general, the peace had held for over 200 years. The concept of peace had developed a sense that the individual, the sovereign, and the nation were three parts of a whole even though the whole might still be unbalanced.

\section{Comparisons}

The concept of peace thrived in social settings operating under a great deal of order. Hobbes, Locke, and Rousseau all recognized that the relationship between the individual and the community functioning in balance opened the socio-political structure to becoming an orderly organization of societal elements. In such a setting the individual was free where he was not in a state of war. All three writers articulated the function of laws in relation to freedom in society. Rousseau's perspective on social organization led him to espouse the belief that laws brought men liberty. Without them there was no access to liberty, which conveyed a new sense to the thinking about the socio-political structure of Europe. Essentially he meant “...men cannot alienate their liberty. In truth, what Rousseau is saying is that instead of surrendering their liberty by adhering to the social contract, they convert their liberty from independence into political and moral freedom, and this is part of their transformation...into men living humanly according to reason and conscience" (Cranston 34). Hobbes saw constraints of any kind as robbing the individual of his freedom. When laws were "silent," the individual had more liberty. Locke felt that laws in the abstract did not constrain the freedom of the individual. There were good laws and bad laws, which had the potential of diminishing the freedoms of individuals. But Rousseau thought there were "true law[s] and actual law[s]. The social contract [was] law in true sense. He [thought there was] a need for the lawgiver" 
(Cranston 38). For Rousseau the majority held sway, but not by will. The majority held sway by interpretation. The majority should guide, an idea that seemed to be an early suggestion of the value of representation.

The sovereign was a critical figure conceptually in the treatises these writers presented. Rousseau's view of the sovereign differs from Hobbes' and Locke's and indicates a maturing of the concept. In fact, Rousseau's vision is more easily aligned with late-Modern estimations. The proliferation of the viewpoint that saw a necessity in the $20^{\text {th }}$ century for peace movements and a widely expressed peace consciousness fits well in the wake of the influence of Rousseau's writing. "For every individual...may have a private will contrary to, or different from, the general will that [one] has as a citizen. [One's] private interest may speak with a very different voice from that of the public interest." However, as a citizen "the social pact shall not be an empty formula...that whoever refuses to obey the general will shall be constrained to do so by the whole body, which means nothing other than that [one] shall be forced to be free" (Social Contract I, 7). Personal freedom for Rousseau came in remaining a part of the socio-political framework. Also, the individual for Rousseau attained a moral freedom when he entered the socio-political framework and left his natural state. Being a citizen was the ticket to ensuring that individuals within society continued to live in peace. The concept of peace continued to be viewed as a viable option for the state. Maurice Cranston elaborated on an aspect of Rousseau's thought that could even represent the basic reason for the setup of the United Nations. "Indeed the Lawgiver repeats in the state the role that the Tutor performs for the individual... men left alone will be led by their own passions and folly into disaster; they need someone to save them from themselves" (43). 
The maturing in Rousseau of the socio-political understanding of the individual in the post-Westphalian social order was reminiscent of and analogous to Heinrich Wölfflin's perception of a shift in painting from the linear to the painterly viewpoints in art. The complexities between the individuals' needs and desires and the concept of the freedom of the individual by degrees given that he relinquished some personal freedoms for societal benefits, relates - as a shift from self-focus to socio-political integration-to the addition of complexities to painting, and how relations among the depiction of aspects of society in differing settings appear in painting. For the first time, in Rousseau's writing, the culture received a sense of the beginnings of an expressive style that presents Wölfflin's baroque aspect of unity and depth in the same light that Rousseau presented a union of parts based on a single theme. There were reference points in Wölfflin's theory that were applicable to more than one art form. In Rousseau's case, he represented a cultural development in the expression of socio-political thought from Hobbes especially through Locke. The development was one from a multiplicity of ideas in their aspects and details on the theme of political philosophy and governance where Hobbes presented a concatenation of ideas that built on each other but seemed to maintain in their way a sense of separation, at least, in their presentation. Rousseau, on the other hand, presented the ideas in his Social Contract in less detailed a format, except the reach of those ideas seemed a little more broad. Of course, Rousseau wrote in the wake of Hobbes and Locke, so the depth of Rousseau's thought benefited from their treatises. Still, Rousseau's viewpoint relied more on the broader theme of what the individual gained by remaining a part of society. He seemed to offer something more prescriptive of benefits overall than Hobbes, for example, who seemed more focused on the pitfalls of an individual who 
maintained his focus on his own desires. Hobbes in Wölfflin's terms seemed to lay his stress "on the limits of things," while in Rousseau's writing these "things" merged. His was an "apprehension of the world [that allowed for that world to present itself] as a shifting semblance" (Wölfflin 14). The shifting nature of the socio-political climate and the development of the concept of peace was an earmark of the early-Modern viewpoint.

One may move from an apprehension of the concept of peace during the earlyRenaissance period in Tuscany through the eyes of Marsilius of Padua invested with a notion of tranquility to a view of peace as a balance between a collection of individuals and their desires tempered by the moral freedom that arises when individuals join the society in which they must live under certain laws. Hobbes's connection to the $20^{\text {th }}$ century came through Freud while Rousseau's came though the actual viewpoints that emerged in personal writings in times of peace. Based on the way he wrote his Confessions, he set up a style that remained a part of the culture, especially in personal writing. He also introduced a notion of silence as a characteristic response to life, which again cropped up in the $20^{\text {th }}$ century in Wittgenstein and Hauser, perhaps in response to "the terrifying rise of precisely those forces which drove us out of Europe in the 1930s: nationalism and intolerance," which elicited a particularly Modernist response (Panofsky 344).

The art of Rubens and the writings of political thinkers after the Treaty of Westphalia provided a scene for the intellectual development of the west, which included the development of the concept of peace. As did "nations," according to S. C. Vestal, "develop in protected areas" (65), so did the culture and intellect in the west. This had 
been true of Rome and Siena. Another paradigm shift in the Westphalia period was that the Treaty itself allowed cultural protection. Westphalia was a conceptual protected area within the culture. Peace again became a concept in 1648 , but in a different way than it had been in use previously. In the early-Modern era, peace was no longer a term to be employed propagandistically as a measure of an amount of order brought like a product by a governing body to a populace. In the early-Modern era the concept of peace had become a frame-of-mind, a viewpoint, and soon a state-of-being with real differences in quality-of-life for peoples within a nation. Peace was no longer a word useful to a governing body solely for its uses. Peace by this point exposed a desire, as well, as a desired state-of-affairs employed by the state. What Vestal mentioned as "inaccessibility" was discussable after 1648 as a term relatable to ideas. Could it have been that the Age of Reason allowed for territory not to be the only goal for conquest? Could no one have seen a desire for the conquest of the mind as a parallel aspiration to conquest for territory or resources? Even the Renaissance understood this dichotomy, but there was a difference after Descartes. The active mind across the culture began to rise in importance. And, in the thinking of Hobbes and painting of Rubens, the resurgence of education after a period of war strengthened the aspiration of society to promote the growth of the mind. For a time Westphalia became an intellectual analogue to a mountain range between two neighboring countries that ensured peace. As long as the natural topographical boundary between the two neighbors was in place and difficult to breach, the range assured peace between the neighbors.

Horizontality was there in what is trampled in Horrors of War. The trampled landscape of the western mind suffered in the tension between war and peace. The 
landscape may have been trampled, but it was still reclaimable in fact. Horrors of War may not have shown deep space, but there was a hint of sky. But there was a deepness in the conceptual realm that equated to a deepness of nature. Something big was affected. The main question for $21^{\text {st }}$-century humanitarians is to what degree were the people of the early-Modern era the same or different from the people of other ages. As the periods crept closer to contemporary times, the answer was "not much." The development of the concept of peace was still crucial to allow for the enjoyment of life.

Characteristically in the development of the concept of peace, there are certain parallels to acknowledge between the Westphalia period and the period immediately following World War I. Both wars had a cataclysmic effect on Europe. In fact, some viewed both as completely meaningless in purpose other than to express a gross desire for the expression of greed. According to Geoffrey Parker, "C. V. Wedgwood, for example, in her classic study of The Thirty Years' War [(526)], stated baldly: 'The war solved no problem. Its effects, both immediate and indirect, were either negative or disastrous.... It is the outstanding example in European history of meaningless conflict"' (Parker 216217). Her perspective was interesting in that she acknowledged the people and their voice, except they were powerless to stop the machinery of war. Wedgwood herself, continued in writing of the wishes of the populace that "nearly all were genuinely anxious for an ultimate and better peace... They wanted peace and they fought for thirty years to be sure of it. They did not learn then, and have not since, that war breeds only war" (526). These words echoed the sentiments from World War I, as well. Of course, she wrote during World War II, so her sensitivities were acute, contemporary to her times, as well 
as accurate. It took the great wars of the Modern eras finally to wreak such a destruction on European soil and the western mind and emotions that the events deeply shook European psychology before the concept of peace could fully bring the power brokers to their senses. After World War II, it was easy to see how the $17^{\text {th }}$ and $20^{\text {th }}$ centuries resembled each other. The peace of Versailles shared many parallels with the peace of Westphalia. Nearly 300 years turned out to be the length of time it took to forget one need for peace with another. Geoffrey Parker agreed in relation to Germany.

Until 1939, the Thirty Years' War remained by far the most traumatic period in the history of Germany...also...various nationalist political groups who wished to represent the peace of Westphalia, and indeed the entire war, as a monstrous iniquity perpetrated on Germany by foreign powers, especially France. After 1919 , parallels were...drawn between the peace of Westphalia and the settlement at Versailles (Parker 215).

Similar to the Versailles Treaty in 1919, there were in some historians' estimations the judgment that "certain provisions of the peace of Westphalia threatened...new hostilities" (217). And as heard frequently in accounts of judgments in the aftermath of World War I, the decision to go to war in both the $17^{\text {th }}$ and the $20^{\text {th }}$ centuries was made with no thought of the will of the people (Wedgwood 526). The development of the concept of peace went on hiatus during both these periods. During the Thirty Years War, apparently there had never been any governmental channel through which the will of the people could be heard, let alone exercised. The power brokers paid mere lip service to the desire for peace. "When it came to practical action they were always prepared to fight for a little longer in order to gain their own particular end-and make a more lasting peace... [fighting] merely for the relief of expressing in action sufferings too deep for words" (Wedgwood 474). One difference between Westphalia, though, and Versailles in 1919 was that the Congress of Westphalia occurred while 
fighting continued, which made the resolution to cease hostilities an imperfect end to the war. There were doubts about whether the fighting might not resume (505). Under conditions such as these, the social order built from basic elements and itself felt insubstantial as well, which undermined the development of the concept of peace and all the stability a peace might bring.

The development of the concept of peace, though, began to return when living conditions finally began to improve. Wedgwood wrote that from about 1622 for another 50 years, prices fell, wages rose... (511). In Saxony, for example, the peasants rose up with the aid of government against the nobility. During the Thirty Years' War, peasants had left their land, "drifted into the towns and learnt trades." They now returned and raised their standard of living. But, in Saxony the landed aristocracy "compelled the Elector...to issue a series of laws forbidding the peasant either to leave his village or to ply any industry in his home" (517). Class and caste divisions were re-established and continued. Yet, as the west would experience again in 1919, the peace of Westphalia, while serving to "settle the disputes of Germany with comparative success because passions had cooled, was totally ineffectual in settling the problems of Europe....The Peace of Westphalia was like most peace treaties, a rearrangement of the European map ready for the next war" (525). As usual, the power brokers and the populace saw from different sets of eyes. At the time of the Treaty, however, the populace had little voice in the socio-political scene.

European socio-political turns were complex, but for the purposes of the development of the concept of peace, the period of Westphalian influence began to wane 
finally around 1871 when the rivalries among European nations began to emerge. These rivalries continued until the outbreak of World War I. Norman Davies noted that the rivalry period succeeded a period of concessions in which "constitutions were granted [and] the last serfs emancipated... [and this period was] aggravated by diplomatic realignments, military rearmament, and colonial competition" (763). In 1899, The Hague Conference created a World Court that demonstrated the importance of a World Court in dealing with the Balkan crisis. But, the Court's influence was not strong enough yet to succeed. The Court was "assembled at The Hague...to discuss disarmament, the arbitration of international disputes, and the rules of land warfare" (Davies 875). "In the first dozen years of the $20^{\text {th }}$ century, the long European peace still held" (874). Then, the concept of peace was quickly buried again in the long descent into the devastating world wars of the $20^{\text {th }}$ century.

S. C. Vestal acknowledged two ideas at the beginning of his study, The Maintenance of Peace. The first was that man considered himself the ultimate creation, in fact the reason for the act of creation. Secondly, Vestal stated "the maintenance of peace is the greatest problem of political art and human wisdom" (3). Man created the need for the development of the concept of peace. Vestal in 1920 drew a comparison between America and Europe that said much about the particularly unique situation of Europe and why the concept of peace was such a worthy topic for consideration. In America the government represented all the people across the country and even in areas of the country far beyond the reach of some people. A framework operated to keep representatives and constituents in close contact with each other, at least, on topics relating to current 
concerns. If a serious division developed between the two, the representatives did not get re-elected. "In other lands, notably in some of the countries on the continent of Europe, the people belong to different races, speak different languages, have different ideals, adhere to widely different religions...they are held together only by the aid of strong military forces“ (15). His comments were appropriate to the Westphalia period as well as the period immediately after World War I.

In order to thrive, the concept of peace in the west depended for its development on the socio-political organization in many historical periods even though advancement was slow. In the Roman empire the concept of peace as it was utilized by the emperors corresponded to the degree of order in the city. The emperor ensured the idea of order succeeded and he was able to declare peace. After the regional civil wars in the region of Tuscany in the early Renaissance, the Nine in Siena had been able to maintain peace in the commune, which benefited from their maintenance of order. However, the breakdown in services began to show in the socio-political structures and the Nine relied on the powers of propaganda the concept of peace contained in order to ballast their own popularity and legitimacy as rulers. So, the maintenance of order in Siena was actually a maintenance of the concept of peace on behalf of the power brokers, which began to develop naturally there, rather than in imperial Rome where the concept of peace was fait accompli dictated by the emperor. Among other political theorists and treatise writers of the Westphalia period Hugo Grotius was able before the Treaty of Westphalia and Hobbes, Locke, Rousseau were able in the decades after the Treaty to codify the aspects of social structures that needed to hold together to shape the fabric of society and included contributions from the populace. In their writings were articulated the benefits 
of order, which had became necessary to articulate after the socio-political flux of the Thirty Years' War. In any historical period, the method of achieving order emerged from the thought of the time and this period was no exception, having been a period that allowed for "favorable activities of the mind" (Zampaglione 135). These favorable activities opened up the culture for the first time historically to the voices of members of the populace, who were able to articulate a more urgent need for socio-political order than previous societies had expressed. By the $20^{\text {th }}$ century, the expansion of the order the west recaptured in the early-Modern period would not be the kind that developed the concept of peace. Even so, the expansion of order after World War II was. As Viktor E. Frankl concludes in Man's Search for Meaning "after Hiroshima we know what is at stake" (179). 


\section{CHAPTER V \\ $20^{\text {th }}$ CENTURY}

In the $20^{\text {th }}$ century, the aggressive drive in the western character fulfilled itself in two great wars. Questions regarding the effectiveness of western governance arose in a significant way with the idea that the power brokers would realize that their real power located itself in the consent of the governed (Van Dyke 240). By grabbing the reigns of power too tightly the power brokers had upset a natural balance of power that would allow governance to proceed without resorting to wars to solve political problems.

Midway through the century the concept of peace developed to the point where European wars culminated with the establishment of the United Nations, which sought to benefit the world by charting a path to peace throughout the world. Even so, a developed concept of peace did not completely solve the international problems that lead to wars. A developed concept, though, did announce the intention of international governments in the west and the world to work for peace even if they first took missteps in achieving that goal.

The desire for peace during the late-Modern era, the period of the first half of the $20^{\text {th }}$ century, had yet to forestall the inevitability of war. After World War I, the Great War, the League of Nations accompanied the Treaty of Versailles into existence on 10 January 1920 (Davies 949). Support for the League was 
nothing more than sporadic on behalf of the major powers in its membership. However, one effort to strengthen the League's shortcomings stood out. In 1928 the Kellogg-Briand pact "for the renunciation of war was eventually signed by 64 states, including the USSR."

Thanks to the ambivalent attitudes of the Western powers, the League was not empowered to challenge the general European Settlement, which the former thought they had put into place in 1919-20. A fatal ruling determined that demands for Treaty revision could not be accepted as a "dispute" under the terms of the Geneva Protocol. The principle of unanimity, which governed voting in the Assembly and the Council, ensured that no decision could ever be taken contrary to the wishes of the Powers. The crucial Disarmament Conference did not meet until 1932, by which time rearmament was well advanced in the USSR and was soon to be launched in Germany (Davies 950).

The clouds of war gathered again in the 1930s leading from the Spanish Civil War through British and French appeasement with Hitler in 1938 culminating in blitzkrieg over Poland in 1939.

In a 1933 essay entitled, "Why War?" Sigmund Freud and Albert Einstein exchanged views on continuing socio-political upheavals in Europe. While discussing Europe's predicament, Einstein wrote, "law and might inevitably go hand in hand, and juridical decisions approach more nearly the ideal justice demanded by the community" (200). However, he did not qualify his statement. Presumably he meant for good and bad, because he also stated "the intelligentsia is most apt to yield to...disastrous collective suggestions..." (201). One of the reasons Einstein initiated his exchange with Freud was because Einstein felt that "as for me, the normal objective of my thought affords no insight into the dark places of human will and feeling" (199). Dark places in the soul, Einstein realized were the repositories of the driving forces toward war in Germany in the 
1930s. Freud understood dark places as had Thomas Hobbes in the $17^{\text {th }}$ century. Einstein expected Freud's methods would allow him to think "outside the scope of politics" to see beyond "obstacles." Einstein recognized his own vision was clouding his humanitarian desire. To him Freud did not seem to lose time wanting to break free of the limitations in sight. Even though Einstein had identified the relationship between law and might, he was "immune from nationalist bias" (200).

Much of the conflict Einstein, Freud, and others felt acknowledged the brittle state of affairs of the concept of Nationalism begun in the Westphalia period and carried through as far as the $20^{\text {th }}$ century.

I must confess that I am bitterly disappointed at the narrow nationalist bias to be found even among men of great stature. I must also say that my once great respect for the politically advanced countries has much declined. ...it becomes apparent how sad is the thing which is worshiped as the "fatherland." Frontiers make little difference; states are much the same everywhere. Should relations, because of such an unreal concept of the State, really disintegrate among men who have come to esteem one another through personal and professional contact? I cannot possibly accept it; it would seem that men always need some idiotic fiction in the name of which they can hate one another (Einstein on Peace 11).

Freud expressed his viewpoint in Civilization and Its Discontents.

A good part of the struggles of mankind centre round the single task of finding an expedient accommodation-one, that is, that will bring happiness-between this claim of the individual and the cultural claims of the group; and one of the problems that touches the fate of humanity is whether such an accommodation can be reached by means of some particular form of civilization or whether this conflict is irreconcilable (43).

The need to assert the presence of the concept of peace in daily life grew. Freud identified "the greatest hindrance to civilization" as "the constitutional inclination of human beings to be aggressive towards one another" (89), which had been a driving impulse in western antiquity when Rome was establishing its republic and securing its empire. Overcoming the results of the impulse to aggression and realizing the 
development of concept of peace in the culture was the great civilizing desire operating in western culture. Of aggression Freud wrote in Civilization and Its Discontents

The inclination to aggression is an original, self-subsisting instinctual disposition in man...it constitutes the greatest impediment to civilization. At one point in the course of this enquiry I was led to the idea that civilization was a special process which mankind undergoes, and I am still under the influence of that idea. I may now add that civilization is a process in the service of Eros, whose purpose is to combine single human individuals, and after that families, then races, peoples and nations, into one great unity, the unity of mankind.... But man's natural aggressive instinct, the hostility of each against all and of all against each, opposes this program of civilization. This aggressive instinct is the derivative and the main representative of the death instinct which we have found alongside of Eros and which shares world-dominion with it. And now, I think, the meaning of the evolution of civilization is no longer obscure to us. It must present the struggle between Eros and Death, between the instinct of life and the instinct of destruction, as it works itself out in the human species. This struggle is what all life essentially consists of, and the evolution of civilization may therefore be described as the struggle for life of the human species (69).

In the place of the way in which the culture had been accessible for centuries through an awareness of public policy as a bellwether useful for discerning the mood of an era, the $20^{\text {th }}$ century produced different types of responses in the wake of its events. One avenue that lead to the sense of the reality of the era informing the investigation of the development of the concept of peace was through psychological investigations of the European soul. The development of the concept of peace still ran parallel to the development of civilization. Freud's identification of aggression as a human inclination that impeded the development of civilization recognized the cause for the break in the development of the concept of peace during the long war years.

The $20^{\text {th }}$ century, after the late-19th-century breakdowns of the European sociopolitical order that led into wars, saw Europe became a laboratory for war among nations at the expense of the peoples of those various nations. During this time, the concept of peace suffered greatly. Yet it was not merely a defeatable quality expungible from the 
human psyche. Peace was not merely an invention, but instead the deepest mark of our civilization. Especially in the Modern eras after the Peace of Westphalia, people were the ones who continued to civilize civilization, the governed who brought the concept of peace to the forefront of societal awareness. The power brokers had a different level of interest in peace per se. They habitually would accept peace only as a byproduct of their reach for power as well as their self-interest. Their solutions to governmental and political stresses were sometimes opportune in the benefit their efforts extended to the populace; however, their methods may have seemed facile to the general public even when the private reasons drove the methods to conflict with the concept of peace. Albert Einstein mentioned the "idiotic fiction" that "once... was religion. Now it is the State" (Nathan 200).

Tenets of co-existence and points to notice in discussions of war and peace that had been at issue since the Treaty of Westphalia guided expectations of humanity to which belligerent nations acceded or for which they bore responsibility. In the $20^{\text {th }}$ century those treaties and agreements were tested directly in WWI followed by the 1919 Peace Conference, which led to a restructuring of European borders and a further breakdown of national stabilities on the continent. Furthermore, when war broke out again in WWII, the west led itself to a point where the stakes grew so high, post-war agreements had to stabilize the socio-political world in order for the culture to be able to continue.

The danger point for the west in the $20^{\text {th }}$ century was the period around the formulation of the Peace of Versailles, which entirely satisfied no one. President Wilson 
spearheaded an effort for the League of Nations idea; however, his perspective as the President of the United States, a savior nation coming to the aid of Europe, guaranteed that he would not completely comprehend the politics among European nations.

Henry Van Dyke reported President Wilson's statement in his Address to Congress, 19 April 1916. "We owe it to a due regard for our own rights as a nation, to our sense of duty as a representative of the rights of neutrals the world over, and to a just conception of the rights of mankind to take this stand now with the utmost solemnity and firmness." The stand was "that we cannot remain silent while those rights seem in process of being swept away in the maelstrom of this terrible war" (232).

Discussions of peace made by governments should be supported "absolutely with the voice of the people behind them." Otherwise, the voicing is the will of a gang rather than a voice of resolution (Van Dyke 234). In 1917 in the throes of the fighting during the Great War, Henry Van Dyke stated unequivocally in his book, Fighting for Peace, that a discussion of peace terms with Germany was out of the question. Living was "neither desirable nor safe...until that Government is disabused of the delusion that it has won, is winning, or will win" in this war. As long as the government thought thus, it would have been unable to reason on the subject of peace. "A pax Germanica is what it is willing to discuss" (235-236). Here was verbalized the change in its latest form. In this case, the presumptive heir to a pax Romana desired a peace to benefit one government only, allowing itself to satisfy its desires nationalistically, geographically, and politically at the expense of any other group. What Van Dyke exemplified in his statement was the ultimate effort civilization in the West was striving to accomplish. Since the days of imperial Rome when the pax Romana had been seen by those who created the history of 
the world-they-knew as a supreme general achievement in the culture for which there was little if any recorded protest, the centuries passed until the world was no longer willing to accept subservient status to the will of a single aggressive and belligerent governmental point of view. As World War I drew on to the inevitable day when the United States joined its European allies on their battlefields, Van Dyke voiced the hopes of those who wanted a "real pax humana" to come. (236). A nationalistic pax would be no peace. That much had been proved. In the wake of Westphalia in 1648 , there had been negotiations and responsibilities, acknowledgments and agreements nations honored in order to ensure that civilization would continue to progress. Self-interest had had no place in the postWestphalia world when blaming had been set aside in the interest of the general good will among nations and a sense of rebuilding had formulated itself. World War I did not solve the problem of national self-interest in the west. However, World War II did if only because the stakes of waging total war finally grew too high.

The proposal Van Dyke expressed in his book was to make war for aggressors like Germany "more difficult and more dangerous...to set up a new safeguard of peace, based upon justice, and supported by the common faith, the collective force, and the mutual trust of democratic peoples... peace with power" (245). He articulated the growing viewpoint that the populace was gaining an importance in the socio-political order unknown in previous historical periods.

No peace can last which does not recognize and accept the principle that governments derive all their just powers from the consent of the governed, and that no right anywhere exists to hand people about from sovereignty to sovereignty as if they were property (Van Dyke 240). 
President Wilson echoed the growing awareness of the worth of the populace. In his address to the United States Congress on 8 January 1918, he spoke for the oppressed peoples, such as the Russians.

They are prostrate and all but helpless, it would seem, before the grim power of Germany, which has hitherto known no relenting and no pity. Their power, apparently, is shattered. And yet their soul is not subservient. They will not yield either in principle or in action. Their conception of what is right, of what is humane and honorable for them to accept, has been stated with a frankness, a largeness of view, a generosity of spirit, and a universal human sympathy which must challenge the admiration of every friend of mankind; and they have refused to compound their ideals or desert others that they themselves may be safe (466467).

At the time of his address, in the late stages of the war, Wilson's currency as an influential force was great. He extended his sights to create an ethical stance the United

States could bring to the aid of European nations:

We entered this war because violations of right had occurred which touched us to the quick and made the life of our own people impossible unless they were corrected and the world secure once for all against their recurrence.

What we demand in this war, therefore, is nothing peculiar to ourselves. It is that the world be made fit and safe to live in; and particularly that it be made safe for every peace-loving nation which, like our own, wishes to live its own life, determine its own institutions, be assured of justice and fair dealing by the other peoples of the world as against force and selfish aggression.

All the peoples of the world are in effect partners in this interest, and for our own part we see very clearly that unless justice be done to others it will not be done to us. The program of the world's peace, therefore, is our program; and that program, the only possible program, as we see it, is this (467-468).

...we feel ourselves to be intimate partners of all the governments and peoples associated together against the Imperialists. We cannot be separated in interest or divided in purpose. We stand together until the end.

For such arrangements and covenants we are willing to fight and to continue to fight until they are achieved; but only because we wish the right to prevail and desire a just and stable peace such as can be secured only by removing the chief provocations to war (470-471). 
In 1933 Freud stated to Einstein that muscular strength lay in the "small human horde" ("Why War?" 204). "The intention to kill might be countered by a reflection that the enemy could be employed in performing useful services if he were left alive in an intimidated condition" (204). Between the wars Freud was writing about "evolution. There was a path that led from violence to right or law..., [and] right is the might of the community. It is still violence... The union of the majority must be a stable and lasting one" (205). Writing in this fashion, Freud echoed the Roman and Sienese states of affairs, as well as the reasoning in the writings of Hugo Grotius that had preceded the Westphalia period. The culture, especially leading up to the peace of Westphalia, was beginning to see a turn in the will of the populace to be understood as needing the rule of law and reason. The same "game [was] repeated ad infinitum" (205). Of course, this was the Roman and Sienese model as well as what the west experiences today. Probably the ease of conducting peace in Rome and Siena was a result of their small size, at least, within the walls of Rome. "Paradoxical as it may sound," writes Freud, "it must be admitted that war might be a far from inappropriate means of establishing the eagerly desired reign of everlasting peace, since it is in a position to create the large units within which a powerful central government makes further wars impossible" (207). Having written such a statement, Freud still entertained the thought of expressing a desire for a structure similar to the United Nations. "Unifications are created by conquest... wars will only be prevented with certainty if mankind unites in setting up a central authority to which the right of giving judgment upon all conflicts of interest shall be handed over." Still, he could recognize that even with such an authoritative organization, "there is no use in trying to get rid of men's aggressive inclinations" (211). As if to dispel the influence of 
Grotius in the $20^{\text {th }}$ century or to indicate the difference in the historical period, Freud identified the "dictatorship of reason" as "a Utopian expectation" (213). The expansion of order after World War II was the type of order that allowed the concept of peace to develop. As Viktor E. Frankl concludes in Man's Search for Meaning "after Hiroshima we know what is at stake." Freud viewed civilization as a process (198).

In the $20^{\text {th }}$ century, a real change came about in the perception by the populace of the concept of peace. In part, the ideas of reason and natural law had long before lost their hold on people's thinking in favor of nonviolence and later responses to war and governmental conflict. A desire for nonviolence in the culture had not precluded strife. Gandhi expressed his idea about the relation of nonviolence to suffering. "Since [1920] the conviction has been growing upon me that things of fundamental importance to the people are not secured by reason alone but have to be purchased with their suffering. Suffering is the law of human beings; war is the law of the jungle ("On Nonviolence" 345). If you want something really important to be done you must not simply satisfy the reason, you must move the heart also" (346). Perhaps Gandhi had begun to comprehend deeply why the west fought wars that even affected him in India. Richard Barnet held the opinion that "we must assure peace by preparing for war and making governments believe that we will do exactly what we say we will do to protect our positions of strength in the world, including our alliances. Thus we fight in small wars now to prevent fighting in larger wars later" ("The Illusion of Security" 277).

The $20^{\text {th }}$ century wars, total wars, made the development of the concept of peace a difficult endeavor. Relations among European nations kept the specter of war ever 
present. Much of what transpired emotionally among the citizenry of the many European nations appeared as an undercurrent in the evidence of the art and literature of the period. Through the agency of T. S. Eliot's poetry and Pablo Picasso's painting, one could gain access to the psychological undercurrents in the culture. Eliot cycled back in his poetry to the influence of Dante but without infusing his poetry with the early-Renaissance sense of hope. Instead, Eliot ended his Four Quartets on a different note of hope, one that remained after the attainment of the reductive, "A condition of complete simplicity/(Costing not less than everything)" ("Little Gidding" V, 254). Both poets traced their roots to Roman literature. Dante completed a path to knowledge, though, where Eliot completed his cycle with a sense of recurrence in the knowledge he presented. His beginning and end points were the same. Picasso's paintings visited the past, too, in their use of images and motifs that were reminiscent of types from early periods in western culture even if these types did not allude directly to art from the past. With the weight of nearly two millennia of cultural history behind them and their historical location set amid the tumultuous events of two world wars, these artists, Eliot and Picasso, created their work with an influence that had the power to lead the minds of the populace through appeals to their emotions and cultural awarenesses, so the populace could express its collective desire for peace.

The late-Modern era artists and thinkers wrestled with a world of socio-political ideas and threats adding new directions in art, psychotherapy, philosophy, music, physics, and so on. Europe soon came unglued on a grand scale not experienced since the preWestphalia period almost 300 years before. Earth-shattering events changed Europe in the $20^{\text {th }}$ century. World War I during the early part of the century altered the culture and 
socio-political structures irrevocably. In the aftermath of that four-year debacle, there arose cries for peace. The Allies who together conquered the Central powers would redraw the boundaries of European and Middle Eastern nations setting up the political stage for eventual failure leading to a re-igniting of the flames of world conflict rooted in the west.

The literature of this period yielded many voices of educated soldiers who went to war, among them even American writers who in the decade following the war contributed a new literature to the world. In between the two World Wars, the elite literature even had its say possibly for one of the last times on such a scale. Eliot's Four Quartets tried to express a perspective on the changed world landscape, the emotional one as well as the physical. Eliot's The Waste Land poem had already spoken to the sense of ruination that had pervaded the English experience of World War I leaving the socio-political order shattered "in our empty rooms" (V, 410). The emptiness explained the sense of the culture having emerged from the experience of World War I. All appeared ruined. Somewhere there was wailing.

What is that sound high in the air Murmur of maternal lamentation Who are these hooded hordes swarming Over endless plains, stumbling in cracked earth Ringed by the flat horizon only (The Waste Land V, 371).

Even the earth itself had lost topography, flattened as it was from four years of shelling. In art, Picasso made his grand statement against the Spanish Civil War, Guernica, immediately following the 1937 bombing of the town, Guernica. The horrors he depicted in that painting revisited those of Rubens' Horrors of War. But, it was Picasso's later two large paintings made in the early 1950s that expressed a sense of hope in the growing 
path to the development of the concept of peace that culminated in the establishment of the United Nations. In the $20^{\text {th }}$ century, poetry and painting reached deep into the western soul to address the changes and torment brewing in the world psyche. Unfortunately war was nothing new and its agony had previously pervaded the European cultural framework and memory 300 years before. Therefore, different poetic and artistic responses were necessary for the $20^{\text {th }}$ century.

The literary work from the late-Modern era that suitably inherited the mantle of Dante's contribution to the early Renaissance was T. S. Eliot's Four Quartets. The four long poems that constituted the Quartets dated from his late period between the two world wars through the early years of World War II itself. Beginning in 1934, Eliot established in "Burnt Norton" the framework for each poem. He waited six years before producing the other three poems in the series, from 1940-1942. Eliot wrote these poems amid the experience of life in Britain during the early period of World War II. As a result, they expressed an experience that represented the questions and feelings the culture had raised as higher-level thought in the early years of the war. The Four Quartets provided a literature of thought that anticipated questions one might have posed in the dark of night while wondering where the socio-political machinery would lead the culture. Not much in the way of practical answers emerged from Eliot in the Quartets. Instead, differently from Virgil and Dante, Eliot situated the human soul in relation to time, a fitting juxtaposition in the century that plays out its experiences and events in a post-Relativity intellectual landscape.

The Four Quartets offered an emotional range Eliot's earlier "The Waste Land" did not seem to express. "The Waste Land" had appeared in 1922 within four years of the 
end of World War I and participated in the negative point of view that suffused part of the culture at that time. The Four Quartets had more facets to them. They embraced simultaneously a positive and negative side of Eliot's thinking. Their meaning was paradoxical in part and reflected the historical period in which the poems were composed. They offered a redemptive aspect to the culture, which expressed the aspirations of their age and the development of the concept of peace.

Dante had reached into the past to comment on the context of Florentine government and its socio-political effects on the region in which he lived. His writing resounded throughout the culture in many ways establishing a spiritual base for the structuring of the west's spiritual cosmogony. Dante's poetical scene covered spiritual places, Hell, Purgatory, Heaven. Eliot's scene remained in four places on earth, each informed by associations with cardinal metaphysical elements. In the first poem, "Burnt Norton," Eliot restored a narrative device leftover from Dante, which placed the poet where he feels lost in the world. When Eliot published his poem, it was 1934 and the clouds of war may have been gathering already. In the opening passages of "Burnt Norton," a compressed essay on time', the reader senses echoes of what "might have been," but the poet asks, "to what purpose/Disturbing" ("Burnt Norton" 13). The echoes carried the reader to "deception[s]" of real things. The poet and the reader looked at things that have the quality of being "looked at." These things were the metaphysical stuff of the culture at that time and the pure feeling of being caught between two cataclysms, one completed and known in its effects, the other looming. There was nothing tangible there but what was in the mind as "might have been," which fails to

\footnotetext{
'Denis Donoghue identified the first 14 lines of "Burnt Norton" as a unified discourse on time (3).
} 
fade, because the unknown experience was on the emotional as well as socio-political horizon. Eliot set up the poem as a treatise on the emotional and cultural effects on passing time, which were real, but disturbed fundamentally so that the effects that seemed to occur in the aftermath of a great war became the common regard of experience spent in the consideration of what might have been even while knowing exactly what was.

Further, Eliot's was beginning to anticipate another war. In this context

What might have been and what has been

Point to one end, which is always present ("Burnt Norton" I, 9-10).

Eliot explained the unredeemable nature of time in 1934. If the culture was held in an abeyance of existence from the unresolved socio-political setup after World War I, the west was living an unredeemed life and the development of the concept of peace suffered. Dante had taken his readers through the stations of the spirit. Eliot, as E. R. Curtius noted, took his readers past "stations of the mind on its pilgrimage" (389). The physics and metaphysics of the $20^{\text {th }}$ century differed from that of the early Renaissance. What was personal, what had occurred, and what turned objective blurred and became vehicles for each period in a terminal artistic expression that would not repeat itself. Curtius noted many Modern artistic expressions had such a terminal structure to them (390). It was a quality of Modernity that elicited such questions, especially within the timeframe when war determined much in the west. (One may read the "it" as "war.")

Or the purpose is beyond the end you figured...

If you came this way,

Taking any route, starting from anywhere,

At any time or at any season,

It would always be the same; you would have to put off

Sense and notion. You are not here to verify,

Instruct yourself, or inform curiosity

Or carry report. You are here to kneel

Where prayer has been valid. And prayer is more 
Than an order of words, the conscious occupation

Of the praying mind, or the sound of the voice praying.

And what the dead had no speech for, when living,

They can tell you, being dead: the communication

Of the dead is tongued with fire beyond the language of the living ("Little Gidding" I, 34-51).

In the passage, "you" were here to offer prayer, which expressed hope from one who witnesses, itself an activity with a tinge of hope, because witnesses usually were set the task of testifying. Hope became a critical element in the emotional recovery of the culture after war finished.

The passage of time and the perception of time were important in the $20^{\text {th }}$ century. Time frequently underscored literary compositions in the Modernist period. In the $17^{\text {th }}$ century, Hobbes wrote, "[it is a] law of nature that all men that mediate peace, be allowed safe conduct. For the law that commandeth peace, as the end, commandeth intercession, as the means; and to intercession the means is safe conduct" (Leviathan XV, 29). When looking at the development of the concept of peace in the two Modern periods, Westphalia and the $20^{\text {th }}$ century, one can see that in the early-Modern period, besides establishing the structure of nations in Europe for the next 300 years, that even when wars occurred in later periods, it took until the 1950s finally to see some of the tenets of the Westphalia period being fulfilled. Even by 2000 and beyond with the European Union as a socio-political entity, it seemed in post-WWII Europe that "safe conduct" may have been achieved in the fact of the decrease in nationalism and the structuring of the European Union itself. The duration in peaceTIME allowed for achievements that war had trampled in the dust as far back as the Westphalia period. 
Time appears to the reader in various places and guises in the Four Quartets, for example, the waste of time in "East Coker" V, "Twenty years largely wasted," that was largely the time in war, with its different quality of duration. That warTIME could not be called into service positively on either a personal or socio-political basis, could not provide anything for the culture in peacetime.

... the distant panorama

And the bold imposing facade are all being rolled away-

Or as, when an underground train, in the tube, stops too long between stations And the conversation rises and slowly fades into silence And you see behind every face the mental emptiness deepen Leaving the growing terror of nothing to think about ("East Coker" III, 111-116).

Between the wars, the culture seen through Eliot's poetry "fades into silence," a frightening lack of conversation that reflected the stillness of the development of the concept of peace in the 1930s, but the memory and the ideal of the concept as where other ideals existed and shrank from the danger of existence at the same time. In this period between the wars, the concept of peace as with other critical facets of the temporal life were reflected in Eliot's conceit of the end and the beginning.

the end precedes the beginning,

And the end and the beginning were always there

Before the beginning and after the end ("Burnt Norton" V, 144-146).

Throughout "Burnt Norton" images appeared that Curtius believed connected with "the blessed children in Dante's celestial rose (Paradiso 32, 40-48)." "In the rose garden...children are heard laughing among the leaves" (Curtius 384). In Part II was the "mud" and "the changing body"; in Part IV, "the burial"; in Part V "between un-being and being" and "children in the foliage." In these images did the faith of "Little Gidding" collect. 
From the beginning line in "East Coker" Eliot concerned himself with the time of Modernity. The time was cyclical and had an end. "In my beginning is my end." "My" history was plotted. Eliot noted field, stone, and bone-the basic stuff of earth and manin an Ecclesiastical way, suggesting the generational cycle of existence. The development of the concept of peace required generational inheritances, which were obscured during this period of war. In between the world wars, especially on the cusp of the second, the Four Quartets associated from the start a living consciousness with an awareness of the eclipsing of a consciousness of death. In the open field was the empty silence into which much emotion and thought could be poured. Eliot employed many literary styles briefly in "East Coker" I: the biblical cadences of "a time for living and for generation," the Chaucerian "daunsinge" and "necessarye," the Latinate "coniunction." The poet spoke of a first world with life-affirming activities

...the coupling of man and woman And that of beasts. Feet rising and falling., Eating and drinking....

Dawn points...

...out at sea the dawn wind ("East Coker" I, 44-48).

In the day was the silence, at night activities.

In "East Coker" II, the reader encountered the "wisdom" that started wars, the "wisdom of old men," not the wisdom that does not, the "wisdom of humility."

Do not let me hear

Of the wisdom of old men, but rather of their folly...

The only wisdom we can hope to acquire

Is the wisdom of humility ("East Coker" II, 995-8).

In "East Coker" III, the reader detected a hint of Dante underscoring the hopelessness he looked beyond in favor of the kingdom of God. By the time Eliot wrote, the prospect for the world in which the poet existed was bleak. "I said to my soul, be still, 
and let the dark come upon you" for this act was better than the act of resistance.

"Darkness on darkness" and the "nothing to think about" was the subject of this

Modernist thought, the stuff of what one must think rather than the war that had already begun to set itself in motion.

...to get from where you are not

You must go by a way wherein there is no ecstasy ("East Coker" III, 136-137).

In other words, at this point in the culture, to attain the concept of peace, which Eliot may not have believed was possible, one needed to travel through war. The echoes of Dante sharpened stylistically in "East Coker" V where Eliot wrote

So here I am, in the middle way, having had twenty years-

Twenty years largely wasted, the years of l'entre deux guerres... ("East Coker" $\mathrm{V}$, 172-173).

Echoes sounded in the west of that different time that had shaped the perceptions of the populace during the previous war. As happened in the period illuminated by Rubens' Horrors of War, the populace was able to think of prospects (culturally, of course) of peacetime in which the quality of thinking was different. In wartime, the activities of the minds of a culture were compromised because so much of the culture's energy had to go to the prosecution of the war. The sense of the time between the wars Eliot wrote of was as much a part of the war as it was a part of the period between. "The mental emptiness" represented an acute feeling for him, which exposed the horrifyingly uncreative type of silence that was a pure product of wartime or a war-oriented time.

Trying to learn to use words, and every attempt Is a wholly new start, and a different kind of failure Because one has only learnt to get the better of words

For the thing one no longer has to say, or the way in which

One is no longer disposed to say it

... a raid on the inarticulate

With shabby equipment always deteriorating 
In the general mess of imprecision of feeling

Undisciplined squads of emotion... ("East Coker" V, 174-182).

In this rather long passage Eliot identified within the voice of the poet a representative of a particular aspect of the cultural soul, a combination of the desuetude of feeling and fact. The simple attempts of the failure to make words come to the aid of the culture helped the populace express its desires, its disgust with the direction that must have been taken when the power brokers employed the machinery of war to resolve their conflicting desires. At the time of East Coker's composition, the failures of Versailles and World War I were complete. The big words and slogans, such as, "the war to make the world safe for democracy," from the previous war had long proven themselves hollow. There were no longer words to utilize for the renewal of the destruction to come when everything felt itself pulled into the military life. Even the expression Eliot used for the failed emotions had a military slant to them.

"There is only the trying. The rest is not our business" ("East Coker" V, 189). Eliot was aware of the complications of the patterns of knowledge throughout "East Coker." There was newness "in every moment" ("East Coker" II, 85). Yet, the knowledge from the past, sometimes "cannot be deciphered" ("East Coker" V, 196). His conclusion in this second poem of the quartet was that eternal love is what matters, the love that looks beyond the present moment. The emotions had failed and the new war had begun. Yet if the human soul related to the culture in the reality of time, perhaps eternal love would override the devastation of the wars of the $20^{\text {th }}$ century. The emotions offered a time-bound knowledge that sought time-bound solutions to cultural problems. "We must be still and still moving," Eliot wrote, as the culture explored "another intensity...for a further union" ("East Coker" V, 206.) "East Coker" provided a 
completed cycle to the reader. The subject matter was teleological, encompassing beginnings and ends, past and future. However, the present was devastating again in the time-bound experience, so the eternal relation of the soul to eternal time would carry the poet and the culture beyond the effects of war. To gain new knowledge one must have explored beyond what the "here and now" presented.

"The Dry Salvages" tried to articulate within the emotional context of the culture the fact of the sea, "the land's edge," where

there is no end, but addition...

While emotion takes to itself the emotionless

Years of living among the breakage

Of what was believed in as the most reliable ("Dry Salvages" II, 56-59).

Knowledge had once been regarded as reliable, but even so it did not allow one into the inward plane away from the cataclysm of the wars that England and Europe endured. As Eliot moved through his poem, he faced a different knowledge from the one faced by Dante. He entertained in "The Dry Salvages" the notion that the knowledge he thought he had derived from history had become meaningless. The hopefulness of the Westphalia period had fully dissipated in the west by this time, a long deterioration, especially since 1871.

We had the experience but missed the meaning... That the past experience revived in the meaning Is not the experience of one life only

But of many generations...

The backward look behind the assurance

Of recorded history...

Over the shoulder, towards the primitive terror ("Dry Salvages" II, 97-103).

The terror of discovery from the $20^{\text {th }}$ century apparently sapped the century's ability to achieve peace in the way that Dante could have done by the end of his poem. For the moment, "moments of agony" for Eliot's poet were permanent. "The agony 
abides." The concept of peace had masked the terror of the absence of peace.

Fundamentally the concept was lost to the culture in the wars of the early $20^{\text {th }}$ century even though the concept still existed as an ideal embraced by certain groups of the populace who maintained hope. The concept of peace existed in its eternal form frequently inaccessible to the populace during the time of war.

There was a period Eliot remarks on in "The Dry Salvages" "where time is withdrawn" ("Dry Salvages" III, 153). This was the period most suggestive of peace and tranquility and reminded the reader that there was a time different from the warTIME and peaceTIME. All movement, which was not through time, was equal. "The way up is the way down, the way forward is the way back" ("Dry Salvages" III, 129), which applied to the passage of Dante throughout his poem, his way down (Inferno) led to his way up (Paradiso). Those in motion through time, through the culture, changed from their departure to their destination. Eliot provided some degree of hope in the sense that movement was forward. He wrote "fare forward...is your real destination ("Dry Salvages" III, 165). There was hope in movement and hope in the awareness, at least during withdrawn time, of a sense of peace and tranquility.

When there is distress of nations and perplexity

Whether on the shores of Asia, or in the Edgeware Road.

Men's curiosity searches past and future

And clings to that dimension.... ("Dry Salvages" V, 197-200).

As long as war occurs, there is wartime.

...But to apprehend

The point of intersection of the timeless

With time, is an occupation for the saint ("Dry Salvages" V, 200-202).

Existence with its wars and its moments of peace had happened and affected the world. Eliot noticed the impossible union of past and future and seemed to indicate they can be 
reconciled. The assertion "right action is freedom/From past and future" gave him the power to assume a shred of hope-to-come for the culture ("Dry Salvages" V, 225). Time shackled the populace, but the concept of peace could return in the freedom from the intersection of power and peace where power usually asserts itself over peace.

Tranquility corresponded to Eliot's "wonder," peace to his "ease."

I said: 'the wonder that I feel is easy,

Yet ease is the cause of wonder...' ("Little Gidding" II, 108-109).

"Thought and theory" ("Little Gidding" II, 112) were worldly stuff, which Eliot would have preferred to supplant with wonder and ease. "These things have served their purpose: let them be" ("Little Gidding" II, 113). The beast of power-driven, cataclysmic, all-destroying wars needed to come to an end.

Last season's fruit is eaten

And the fullfed beast shall kick the empty pail.

For last year's words belong to last year's language

And next year's words await another voice ("Little Gidding" II, 116-119).

These were the words the poet used to assess his relationship with time and spirit where he hoped to reside. In this passage which Eliot rendered in a simulation of the terza rima Dante had used throughout his poem, one felt Eliot may have even invoked the spirit of Dante as an interlocutor if necessary in the way that Dante had used Virgil and Beatrice as his guides. By the end of "Little Gidding" II, the poet had encountered the breaking day alone as if in empathy with the entire culture deeply enmeshed in the new war.

In the disfigured street

He left me, with a kind of valediction, And faded on the blowing of the horn ("Little Gidding" II, 147-149)

The life of the mind succeeded with great struggle against the events in the world. The concept of peace could carry on in the life of the emotions and thought. 
This is the use of memory:

For liberation...

Of love beyond desire, and so liberation

From the future as well as the past. Thus, love of a country

Begins as attachment to our own field of action

And comes to find that action of little importance

...History may be servitude

History may be freedom. See, how they vanish ("Little Gidding" III, 156-163).

Eliot achieved in Four Quartets a culmination of much of what he had viewed throughout his career as a poet. He wrote using literary principles he had always drawn from and had been one of the Modernists who established these principles originally in his period. Having exiled himself to Britain, he understood the idea of rejection on principle. The times and the composition of the Four Quartets seemed to take everything out of him as if he was tying up the ends of all that he had come to know and understand and respond to, react against, in his experience, especially of the events of his time.

Arnold Hauser, throughout Chapter Two, "Spontaneity and Convention," in The Sociology of Art, noted that artists cannot work and create outside of the context of their own era, because the logic of an artist's historical period will drive him or her to produce work that 1) is a product of the cultural viewpoint and 2) further advances the ways in which the culture is able to operates in its historical period. For example, during the first half of the $20^{\text {th }}$ century, Pablo Picasso depicted views of peace and war specific to his era, extending his style to address the sense of psychic fragmentation felt by the populace at large as a result of their having to develop a system of values to absorb the experience of war. Picasso painted such values, but did so to provide an opening in the culture that amplified the expression of horror specific to his time, for example in Guernica, as Rubens had done for his era in Horrors of War. 
Between December 1951 and September 1952 Picasso, having accepted an invitation to decorate a chapel in Vallauris for which he provided two mural paintings, began his sketches for those paintings (Roy 39-159). He received this invitation after Matisse had decorated a chapel in Vence, the town in which Matisse lived. Picasso "wanted to work in the secular spirit of a "temple of peace"" (Ultimate Picasso 390). Picasso's themes may have expressed the concerns of his time, but also the extremes, which were characteristic of his approach to subject matter. Claude Roy quoted Picasso in a report on his commission. "The first thing that impressed itself upon me was the meandering, bumpy journey of these provincial pitiful and squeaking hearses that one can see passing through the streets of small towns." A bit confusingly quoted and translated, but Picasso was speaking about War. (See Figure 5.)

I could not proceed with each part of the painting as I had done for those built around similar parts, for example the series of horseman [sic] from the Middle Ages in which I developed variations on the mounted figure and the war horse, caparisoned, armored, and harnessed. For months, for years, I was, like everyone else, obsessed with the threat of war; I was haunted by this fear and by the desire to fight against fear. Massacres in Korea came out of this. The painting was disturbing, but it was not appealing (Ultimate Picasso 390).

In the terms of Heinrich Wölfflin, Picasso employed a more closed depiction of his subject matter for War then invested Peace with more open depth. (See Figure 6.) War indicated the aspects of the state of affairs that expressed an ancient identity. Peace, on the other hand, had an appearance that while human was invested with a current-ness uncommon with struggle. Historically peace in practice had been a fleeting concept. Even though the desire for peace had roots, its practice did not. Its time came and went repeatedly. With each recurrence, the force with which the concept of peace asserted itself grew stronger. 
The images in the mural, War, were organized as follows. Peace stood to the left or more accurately a warrior stood with the dove on his shield against a blue background. He faced out from the cool zone of blue pigment while all other symbols of men and horses bearing the dead and living creatures with implements of death face the direction of the warrior with the shield. Picasso established a zone for the warrior, an agent of peace, but one who was armed, which established the figure of Peace for the viewer similarly to Lorenzetti's figure of Peace, who bore an olive branch in her left hand while reclining on a mound of arms. Attached to the warrior's spear in Picasso's War was a scales. The warrior was one of two figures in the mural who had eyes from which to see. He peered in the direction of the other figure who, at the opposite end of the mural, operated as the agent of death. He rode in the wagon drawn by a team of black horses who seemed out of step with each other, partly because they trampled things that got in their way, stepping over uneven ground. In this instance, the horses trampled a book in much the same way as Mars trampled the books in Rubens' Horrors of War. The horses in War also had just trodden over hands in a hole. The agent of death in the cart carried skulls on his back, perhaps skeletons, too, as well as in his left hand a container of pestilence with the lid off. In the right hand, he held ready to strike again a dagger with blood on its tip. The road on which the horses and cart rode is blood red. The horses themselves had hollowed eyes and visible rib cages. Behind the horses were images of five figures armed with daggers, spears, and an executioner's blade for slicing through flesh and bone. These men were presented in silhouette as if they were painted images on the inside wall of a cave or were images in the backs of the viewers' minds. They provided the constant backdrop of the reminder of murderous activity that was a routine 
behavior of war. Picasso rendered this part of the painting flatly while to the left, the warrior with the shield of peace cast a shadow. Only living beings have relief and substance enough to allow the casting of shadows. Grasses grew to the side of the left foot of Peace. In contrast to the scene presented in War, Picasso seemed to suggest there was a point at which peace will come. In fact, the way Picasso presented the scene, Peace was the obstruction in the path of War, beyond which War ultimately could not pass. In 1952 Picasso may have felt this was the state-of-affairs finally arrived at in Europe. In the mural, the trail of blood ended before it reached the feet of Peace. Picasso presented Peace as a substantial foe with shield, scales, and spear ever vigilant on watch against the devastation of War. The background colors in the mural were colors of the experience of war on earth. The green of grass and vegetation, the brown of dirt that seemed to billow up like smoke, the blue of sky and water, yet where the green and brown should have been ran the red of blood. The color of smoke flowed through the mural as well. The fact that Picasso rendered his scene as a dreamlike representation of types gave it the kind of evocative power shared by the Lorenzetti frescoes and the Rubens painting. Not one of these paintings would address or fulfill the needs of the development of the concept of peace had they been depictions or renderings of specific events. The same colors, of course, factored into the information of the mural, Peace. However, the sun was present there and shone down on all fields of activity as if it provided the eye of heaven whose witness offered succor to those on whom it shone. The spectrum of colors and full range of activities showed forth, too. Picasso depicted living things, activity, fruit, balance, birth and nurturing, and horses used for plowing. 
One of the noticeable qualities in the Peace mural was the impression of life derived from the presence of male and female figures. In War, of course, there were only male figures. In Peace, Picasso represented a variety of peacetime pursuits including music, fishing, acrobatics. In the scene, there was an impression of juggling in the balancing of weights and counterweights as though the expressiveness of human endeavors maintained its creativity as art and relational dependence among the people and implements as would a mobile maintaining its viability as moving sculpture. Other endeavors included cooking and writing as well as human nurturing, in the form of a generational "dance" under trees that bore fruit beside a field where other fruit was either growing or stored for consumption. A Mother nursed her child while reading. The sun appeared as a multi-colored eye of peace and nourishment reminiscent of the cold, bare bulb-eye in Guernica, which seemed to be Picasso's departure point for both murals.

Picasso painted these two murals as visual essays on the general mythical characteristics of war and peace in their elemental states as they have existed throughout western culture. A difference between these murals and their visual predecessor, Guernica, which could almost stand in for War, was that the former painting was too specifically a response to a coming war, indeed, to one brief attack on a Spanish town. As such, that painting could not serve as an image that promoted a meditative state in the viewer, which Picasso designed War and Peace to do. Guernica had been an essay on pain and conflagration, the destruction of a town in practice for a coming war, and rage at the inhumanity of the militaristic exercise that theoretically buried the concept of peace for a time. Therefore, War and Peace depicted ideas in the way a prayer for peace suggests a point of view of an ideal state of affairs that may one day realize itself. The 
two murals mediated between the viewer and the world (Elsner 4-5). The development of the concept of peace neared completion when the culture could make room in itself for the meditation necessary to contemplate the errors of its past and the prospects for its future. In Peace and War nothing was limp and lifeless as Picasso had presented it in Guernica, where he presented representative images as representing death. In the two murals, there was a firmness to Picasso's gesture to convey hope. Picasso's War and Peace murals showed the dichotomy of man's attention to both sides of his human drives. Peace was a drive the culture had now isolated to concentrate on with some degree of hope. Picasso indicated the meaning of war as it appeared elementally and nearly harkened back to historical depictions that even may have preceded Rome in some cases. Although the aggression was abstract, it was a definite part of the makeup of western humanity.

Picasso had a history of being responsive emotionally to the experiences of his time, his proclivity reaching a zenith in his mural, Guernica, painted between 1 May and early June of 1937 after the bombing on 26 April 1937 of the Spanish town (Blunt 7, 28). More frequently, though, his responses were to the more personal events in his life. The Picasso murals, War and Peace, exemplified the essence of the perspective Heinrich Wölfflin presented in Principles of Art History. Picasso's murals blended the development of style in painting as Wölfflin established a theoretical underpinning for viewers to receive them. Picasso had returned to a classical, linear depiction of his subject matter, yet evident in the paintings was the still active memory of more painterly features developed in recent centuries. There was a hint of depths painted by a modern hand even though he did not depict the features similarly to other paintings of the time. For 
example, Picasso ignored the postmodernist view of the world. Instead he focused on universal representations to him of images that appealed to local understandings of war and peace, millennia-old concepts in themselves. Even during the $20^{\text {th }}$ century when the culture's war influence reached beyond its boundaries around the world, Picasso mined the intellectual and mythical riches of the west for his murals. His artistic locality remained with the history of western art and culture from Rome to the present, resurrecting images with both personal and cultural depths he was able to employ to enhance the meaning of his murals. Sir Roland Penrose suggested of either painting, using this approach he imparted a local quality to his universal western scenes and tableaux. "Its universal appeal was also to be personal" (377). His return in many ways to the older linear style of western painting, the "personal" after the wars touched and affected the entire world.

Picasso in his way represented these depths in keeping with his own painterly developments. For example, he rendered geometry - spherical shapes - through facets. He rendered planes almost as an abstract form. In keeping with many of his more significant paintings on war, Picasso in the murals depicted flatness, as if this was a quality of his emotional experience during the war, one of feeling boxed in, a feeling that reflected a sense of the guiding subjectivity operating at that time within the culture. The experience of the artists was one where they became familiar with the aggression of occupation, a containment in itself. Jas Elsner's idea of "the collective sense of subjectivity within culture" included the expressions of individuals "construct[ing] a private and more person[al] sense of self' (5). Picasso had remained in Paris during the years of World War II. Generationally speaking, Heinrich Wölfflin stated with local force 
in his conclusion to Principles of Art History, "it is true, we only see what we look for, but we only look for what we can see" (230). Picasso for all his vision belonged to a generation that saw through similar eyes. His plumbed the depths farther than most in his generation, but still his generation defined the limits of his vision and that generation knew total war.

The history of generations did not proceed differently from the history of the individual. If a great individual such as Titian had incorporated perfectly new possibilities in his ultimate style, one could certainly say a new feeling demanded this new style. But these new possibilities of style first appeared for him because he had chosen to leave so many old possibilities behind. No human personality, however mighty, would have sufficed to enable him to conceive certain forms if he had not previously gone over the ground which contained the necessary preliminary stages for his work. The continuity of the life-feeling was as necessary here as in the generations which combined to form any era in history (Wölfflin 230).

Keen established Picasso's brittle and opinionated emotional state under which he painted during World War II.

The threat of the suppression and destruction of culture by war, expressed in War and Peace, had occupied Picasso earlier during the Spanish Civil War... In actuality, the threat posed to Western civilization by war was a very real one; the Prado was bombed during the Spanish Civil War and the Nazis prohibited Picasso from exhibiting his work during the Second World War. More recently, the Soviet insistence on socialist realism in art presented a potential threat to Picasso's artistic freedom, which he countered with War and Peace. [In 1944], Picasso wrote that "art is not done to decorate apts. It is an instrument of war for attack and defence against the enemy" (469).

The concept of peace developed in a way similar to the development of style in art. The focus early on was narrow and later widened to include qualities like perspective, 
painterly rendering, and so on. There were aspects of the concept of peace when fully formed that could not have been applied early on until those early stages had been articulated. Although obvious, these aspects did not address all the problems of peace and war that came up. In two statements, Edwin Ginn elaborated on the problem. "The nations must no longer think of themselves alone" (109). "The balance of power is one of the blind and mute forces of nature and it operates with all the persistency of a natural force" (112). As far as the development of the concept of peace in the west went, it was an interesting idea to consider when Picasso's murals suggested a refurbishment of Lockean concept of tabula rasa, which fit the appearance and juxtaposition of the images in the murals as well as any other representation of western images. In the period of the establishment of the United Nations, the west had passed through the stages of its great wars, establishing a world organization to provide allocation for world governments to confer for the betterment of lives everywhere in the world. Picasso's images suggested an innocent aspect that the west could afford to bear after World War II when the world joined the effort to create the United Nations.

One may sum up the period from the mid- $19^{\text {th }}$ century through the initial years of the United Nations and even through 2003 that show the purpose of Untied Nations as a mediation force. By the mid- $19^{\text {th }}$ century, German aggression as described by S. J. Vestal in The Maintenance of Peace, had been brewing for decades. "In 1849, Prince Hohenlohe, who 45 years later became Chancellor of the German Empire, wrote in his diary: 'If Germany is unified, strong, and armed, she will be able to secure Cyprus, and more besides, in the universal partition"' (469). This was the period of the beginning of 
German aggression in the world. Vestal observed, "Germany has been active in carrying on colonization by peaceful penetration under the guise of immigration and the introduction of kultur. Colonization by peaceful penetration is always a direct menace to world peace" (472). He concluded that "nations must resist peaceful penetration or succumb. No nation can afford to enter into controversy with its own people as to whether they shall obey their own government or that of some foreign power" (473).

By the time of World War I, a new approach was necessary for Europe. The Westphalia era was finished. When the war was over, the years after the Treaty of Versailles and the League of Nations experiment brought as many problems as they had once hoped to solve. World War II was a direct outgrowth of lingering tensions and dissatisfactions lingering from the resolution of World War I by its victors. However, the concept of peace did not regain its foothold after World War I. There had been much peace talk among leaders. But, without American support, the League of Nations was not embedded in the socio-political thought of the time. This statement was proven in the years immediately previous to World War II, when England and France had nothing to bring as a warning to Hitler from a unified confederation of nations. A confederation of nations, thinkers, individuals can always establish their oversight and collective power in the face of a rogue nation or individual and take action or convince the rogue to obviate the need for action by stepping back. England and France attempted a strategy that was more of the character of a Westphalia solution. They tried unilaterally, rather than in concert with the rest of Europe, to contain Hitler. It did not work. Had they approached him in the form of an alliance, similar to Metternich's Quintuple Alliance, the Quadruple Alliance (Russia, Prussia, Austria, Britain), plus France, they may have succeeded in 
stalling Hitler (Davies 762-763). The example of Hitler proved to be a violation of the concept of peace and a regression in its development. Hence, the concept did not return after World War I.

After the United Nations established itself, though, there were war incidents it had to deal with that did not bury the concept of peace. The concept of peace had developed in the west, not in the world. However, out of the development of the western concept of peace emerged an organization that could do the work of peace maintenance for the world represented by delegates from world governments. Therefore, the, Korean War and even the long Vietnam conflict were different wars rooted in old-style socio-political approaches breaking through in the face of the beginnings of a new socio-political scheme. Most historical views are not built from clear-cut, neatly established eras. The remainder of the nations in the world had to suffer much of the same pains as the west had. The west, though, had taken itself to the brink of destruction, especially with nuclear armaments. The development of the concept of peace in the west had brought into being an organization that would possibly be able to head off cataclysms that threatened to destroy civilizations. Ultimately the United Nations became a forum for discussions of problems among nations. Even President Bush cited the Charter for national self-defense as the United States sought the approval of the Security Council in the form of a United Nations mandate before going to war with Iraq in 2003. It was to the credit of those nations that they made their cases for staying out of the war. 


\section{CHAPTER VI \\ CONCLUSION}

The development of the concept of peace charted the development of a desire in western culture to do more than merely avoid war. The development provided a desire to work for peace and its continuance by creating the condition within the culture where peace was the activity the culture expressed rather than war. When a culture is not fighting wars, but is working toward deterrence by maintaining arsenals, the culture is still war-centric. In the west, past power brokers had shown the legitimacy of their power or shown their might even when they had not actively pursued wars. However, throughout the centuries, especially the eras discussed in this dissertation, the populace, represented by its writers and artists, had indicated the undercurrents that seemed to operate within the culture. Nations were still war-centric. Therefore, the peace that resulted was fragile, a peace only because no shots were fired. By the $20^{\text {th }}$ century, even peace treaties, such as, the one in 1919 caused as many problems and they hoped to solve. With this evidence, one could comprehend how the power brokers never turned their attentions away from war, so never turned them toward an active peace. The concept of peace works only when its mirror image, the fact of war, begins to fade. With the establishment of the United Nations, the west had taken its first steps toward investing the concept of peace into an organization with an official policy to maintain peace. The development of the concept of peace came about not just because of the absence of war. 
The populace led the culture toward the true progress of civilization, an active striving for peace.

The accumulated knowledge and awareness of the concept of peace on which this dissertation focuses began in Augustan Rome and developed through the three historical periods. The interplay over the next two millennia between the power brokers and the populace marked a discourse initially based in aggression that grew into a communication that enabled western culture to learn how to wage peace. From Rome came the idea of the absence of war. From Siena and its region emerged a recognition of the importance of the presence of tranquility. During the Westphalia period, the west began actively to reap the benefits of an atmosphere favorable to the activities of the mind. The voice of the populace strengthened. In culmination, however, the first half of the 20 th century brought the horrors of living without none of the contributions remaining from the previous eras. As such, there was despair. But, the need for the communication of ideas increased in the 20th century. This communication bore fruit. After World War II, the United Nations, as an organization chartered to work toward peace, became the most visible evidence of human progress in the west, a developed concept of peace in tangibly symbolic form where the work of maintaining peace could transpire. The west reached a point around 1950 where it waged peace within its confines in Europe while making a first concerted attempt to reach into the world with an organization, the United Nations, whose charter devotes the organization's energies to achieving peace. However, expectedly, the structure of the United Nations itself promoted compromises, which often led to new conflicts themselves that showed the organization to be in many ways a world in microcosm. However, this official organization differed. It did not govern a populace. 
Peace had grown with urgency in the west over the centuries even though the influence of war frequently was near. After all, Sigmund Freud surmised in Civilization and Its Discontents, "And now, I think, the meaning of the evolution of civilization is no longer obscure to us. It must present the struggle between Eros and Death, between the instinct of life and the instinct of destruction, as it works itself out in the human species" (69). To underscore this climacteric of the culture, especially with the socio-political paradigm shift that accompanied the Westphalia period, artists in the early-Modern world, visualized then painted a bleak future, a bleak reality, myths crumbling in the moment, which the governments and nations were unable to rectify. Rubens, for example, in anticipation of the end of the conflict called the Thirty Years' War, painted in 1638, The Horrors of War, which was as much a meditation on the unacceptable continuance of war as a statement on the concept of peace. He depicted not the effect of peace as shown in earlier periods, but the effect on humanity when the concept of peace was ground into the dust. He painted the effect of the absence of peace. Yet, the concept of peace lived in memory or cultural will. From this historical point, the concept of peace resided as an aspiration in the will of the populace rather than as a propaganda point to be used at the will of governments, who, as S. C. Vestal suggests, are always in preparation for war. The populace had to teach the culture to prepare for peace.

In the Modern eras the hegemony of governmental power over the complete control of the concept of peace began to erode. The difference was great between the development of the concept of peace early in the history of the west and the shift in focus and intensity in the concept's development after the early-Modern era when the populace voiced its desires and began taking small steps to affect the policies of governments. 
When the world nations established the United Nations in the late 1940s, the act signaled the concept of peace had developed. In the west peace became an achievement, a subject for continual study and work. The two world wars, bookending a period slightly more than 30 years in duration, more devastating than the Thirty Years' War 300 years before, yielded a similar result. With the forming of the United Nations, it seemed that peace had gained a facility with the promise of an infrastructure and a method that allowed peace to become an achievable end. Now the west had defined its task. Arguably, having developed the concept of peace, the west could guide the initial stages of the United Nations' organization to beneficial results for the world.

The United Nations Charter documented for the first time the desire for peace in an official document using the customary language and form of constitutions, resolutions, and other documents of state. The United Nations was another organization with a structure and a hierarchy. The difference between the United Nations and governments came in the lack of a populace for the United Nations to manage or govern. Its purpose was articulated clearly in Article 1 of the United Nations Charter in 1945, in which Section 1 states the work to be done.

\section{Article 1}

The Purposes of the United Nations are:

1. To maintain international peace and security, and to that end: to take effective collective measures for the prevention and removal of threats to the peace, and for the suppression of acts of aggression or other breaches of the peace, and to bring about by peaceful means, and in conformity with the principles of justice and international law, adjustment or settlement of international disputes or situations which might lead to a breach of the peace; 
2. To develop friendly relations among nations based on respect for the principle of equal rights and self-determination of peoples, and to take other appropriate measures to strengthen universal peace;

3. To achieve international co-operation in solving international problems of an economic, social, cultural, or humanitarian character, and in promoting and encouraging respect for human rights and for fundamental freedoms for all without distinction as to race, sex, language, or religion; and

4. To be a center for harmonizing the actions of nations in the attainment of these common ends.

The organization in charge of overseeing "common ends" and that its members addressed the purposes of the charter consisted of the same type of governments that had always been empowered throughout the history of the west. These were governments operated by officials and dignitaries who had their agendas, of course, but who did or did not find ways to work together to maintain peace in the world. Articles 4 and 11 of the Charter established membership in the organization's official assemblies, establishing parameters within which member nations had to labor.

Article 4

1. Membership in the United Nations is open to all other peace-loving states which accept the obligations contained in the present Charter and, in the judgment of the Organization, are able and willing to carry out these obligations.

\section{Article 11}

2. The General Assembly may discuss any questions relating to the maintenance of international peace and security brought before it by any Member of the United Nations, or by the Security Council, or by a state which is not a Member of the United Nations in accordance with Article 35, paragraph 2, and, except as provided in Article 12, may make recommendations with regard to any such questions to the state or states concerned or to the Security Council or to both.

If one would apply a hermeneutical perspective here, the developed concept of peace would indicate a "manifest[ation of the] mental content" of the entire culture 
(Dilthey 218). During the early $20^{\text {th }}$ century, the growing sense of exhaustion vividly evident in the arts of the time-in Eliot and Picasso and sensed as futility in the Einstein/Freud correspondence; Freud had provided Einstein an explanation of aggression that may or may not have soothed him-fed into the need to reconnect their great and cultured intellects to a simpler expression, one rooted as far in the past as possible. They were completing paths to western understanding and knowledge. However, given the events they suffered through in the first half of the $20^{\text {th }}$ century, their knowledge had to be renewed.

Regarding the concept of peace from a $21^{\text {st }}$-century perspective, the image one conjured may have represented a particle of the objective mind of western culture that indicated the apparatus needed to ensure the maintenance of the order that governed the entire western culture. It was as if one was viewing a secure memory from early childhood that illustrated the patterns by which people had lived (Dilthey 221). About this objective mind, one may make a couple of statements. The stability of the concept of peace here resided in its development. An interpretation of it, though, was fluid because of a change in the objective mind during the historical span of time from the Roman empire to 1950. Objective mind, itself, underwent changes over time. For example, the language of any previous historical period under consideration changed. Populations ceased subscribing to the values of past eras. Yet, finally, the west understood the concept of peace through its historical development. People understood the peace almost as allegorically similar to the way the Sienese had been led to understand their own commune's relationship to the concept of peace. They knew the extent of the levels of meaning in their culture. They assimilated the parts first, interpreting the concept of 
peace one segment at a time. In that way, they attempted to enter a hermeneutic circle of the concept of peace and its development with the start of an awareness of what significances the concept of peace bears.

The awareness first was a self-awareness as with children. Paul Ricoeur would consider this explanation to be metaphorical. In "Metaphor and the Problem of Hermeneutics," he wrote

From one point of view, the understanding of metaphor can serve as a guide to the understanding of longer texts.... [In this instance the "text" may be the explication of the development of the concept of peace through the history of the west.] The point of view is that of explanation; it concerns only that aspect of meaning which we have called the "sense," that is the immanent pattern of discourse... The other point of view is that of interpretation proper; it develops the aspect of meaning which we have called "reference," that is the intentional orientation towards a world and the reflexive orientation towards a self.... [One may] proceed from metaphor to text at the level of "sense" and the explanation of "sense," then from text to metaphor at the level of the "reference" of a work to a world and a self, that is, the level of interpretation proper (171).

When attempting an interpretation of the cultural evidence that articulates the concept of peace, one realizes quickly that an observation of the texts must proceed without the benefit of inhabiting the minds from any of the periods in the study. These texts are the remnants of what one may be able to construe as evidence of a general type of a developing western thought. In the late Modern era, as a culture, the west's conception of the developed peace parallels the west's conception of western Self.

The three concerns Gerardo Zampaglione offered in The Idea of Peace in Antiquity delineate the edges of a theoretical forest of the concept of peace. The focus of this dissertation generally has been on overlooked trees nestled deep within the recesses of this forest. One of the most significant trees in this forest has been the one representing the western practice of dialogue - communication - within the culture. Throughout the 
periods in the history of the west various dialogues occurred back and forth in differing genres among the artists parallel to the development and exercise of governmental practices. However, throughout the history of the west, painters, architects, writers, social critics, philosophers and thinkers have all worked with socio-political concepts and added depth, scope, and reach to the culture's ideas from Rome to the $20^{\text {th }}$ century. The artists allowed the voice and will of the populace, regarding the need for peace, to strengthen throughout each series of wars the west endured. The end result by the early $1950 \mathrm{~s}$ became the development of a structure that facilitated the realization of the west's hopes for a successful application of the concept of peace in the forest that is the "world." The west substantively knew its own interior makeup. It knew the desire of peace from offensive and defensive viewpoints. Dialogue on this subject had grown throughout western history. The culture has grown more adept at using dialogue to achieve the knowledge it needed to move in directions toward peace. And so, the idea of the League of Nations and the establishment of the United Nations structured formal settings in which real dialogue in the world could continue. In this respect, the concept of peace represented quality-of-life issues rather than quality-of-rule.

Communication throughout the socio-political structure was critical for the development of the concept of peace. Michel Foucault insisted on the importance of speech as not only the mode in which interlocutors conveyed a sense of our "conflicts and systems of domination." Indeed, speech was the very object of our conflicts.

I am supposing that in every society the production of a discourse is at once controlled, selected, organized and redistributed according to a certain number of procedures, whose role is to avert its powers and its dangers, to cope with chance events, to evade its ponderous, awesome materiality ("Discourse" 216 ). 
Foucault got at the mode in which western culture expresses itself. One could view a western dialogue, its organized or redistributed expressions, throughout the history of western culture, as a series of prohibitions on the part of those in power. Throughout the history of the west, the power brokers have tried to hold onto the reigns and the language, the dialogue of power. Very slowly, the popular voice insinuated itself into the western dialogue of power, influencing the development of the concept of peace. In peaceful times, one might have been able to dissolve some of the barriers that affected the struggle to develop the concept of peace. The paintings examined in this dissertation have provided access to emotional undercurrents of the socio-political experience in various historical periods that the populace might not notice because power brokers have tried to shield the populace from the full brunt and pleasure of experience. The power brokers held onto power. Different eras obscured different meanings, too, so the paintings and literature from each era told unique stories whose meanings may have shifted or expanded in comparison to those from other eras. Of course, the literature of those eras additionally opened up the culture to a rendering of an author's point of view. However, between the lines in the literary works lay an expressed message unique to the time and frequently hidden without the clarity of a single viewpoint to draw out the message. But, the peace efforts, especially in the $20^{\text {th }}$ century bore fruit and the voices calling for real peace coalesced. Of this period, Michael Howard wrote, "the West [including the United States] was now beginning to constitute a real cultural community" (79). In the west, the relationship of individuals to the world in regard to their awareness of and association with the activities of governments internal to a nation and among multiple nations was more immediate than it had been in the period before the world wars. The transmission of 
news and information about events and the governmental responses to events ensured a higher degree of public response to them, which allowed more opportunities for dialogue in the west than in the past. At the time the United Nations organization was established, the world had shrunk in terms of communication. Western culture benefited from that change. As a "real cultural community," the west's concept of peace was poised to become a strong deterrent to war as a solution for conflict among nations.

The development of the concept of peace brought the culture to an alternate point of view when compared to its beginnings in Rome. It opened up the culture to a development of the west's collective qualities, which essentially measured its humanity. Literature and art expressed this humanity by correlating its artistic expression with the collective voice of the populace. A developed peace was the creation of the culture, the desired artifact of the west enhanced in stages from one historical period to another. Arnold Hauser might have suggested that as with art, peace is of its time (77). So, the development made sense since the passage from period to period brought with it the necessary conditions for peace to develop (85). "Works of art [and literature did] not contradict one another" and, did not supplant each other significantly. They seemed "relevant or irrelevant..., rather than...true or false" (86). Therefore, the picture of the concept of peace accumulated with one piece informing the other, but no one part of the picture representing the entire development.

The concept of peace in the west had defined itself by the early 1950s. Through 1953, though, there was a distant war-Korean - that stirred up memories of previous war. This Korean conflict was not a threat to the concept of peace in the west, per se, because it constituted a war-at-a-distance. However, there was one stumbling block about 
the Korean War. It seemed reminiscent of the Roman empire in the sense that early on the United Nations may have seemed to be a central Rome conducting a campaign in a far-flung territory while the west-Europe and the United States-in the guise of a "central Rome" suffered no ill effects from the fighting. The difference was the United Nations was not capturing territory.

The concept of peace stabilized the factual peace among western nations since World War II. Each western historical period added to the development of the concept, moving it further toward a definition that aspired to achieve an active peace among nations where the wills of the rulers and the populace intertwined their efforts and desires to avoid wars. The late Modern era had greater practice in the issues of peaceful coexistence because the west in the 1950s had accumulated sufficient world experience to handle the needs of peace.

In the west the social function of the art and the artist changed depending on the historical period. In Siena the creation of the art echoed the prevailing temper of the socio-political structure and validated the system that governed the communal cultural life. In the Westphalia period, artists and their creations began to affect the social order by exposing political systems as corrupt and the succession of wars as significantly destructive of the culture thus identifying what had become poor leadership. In fact, the prescience of the artists in this period signaled the rise of individual voices and psychological understandings within the culture whether they were individual national and ethnic voices representing cultural homogeneity or simply the voices of the general populace. Rubens' notion of war as a time that cancels education and the arts fits neatly 
into this thought. The power brokers in this period generally had little to lose during the prosecution of any war. If they wanted education for their own socio-political class, they could always attain it.

During the Siena period, the culture began to find its way to expressing depths lost since the era of the Roman empire when the culture was in full development for its time. At that point and because of the breadth of knowledge and artistic expression in the culture, the concept of peace began to emerge. Between the decline of the empire and the early Renaissance in Italy, much cultural perspective in the west was lost. The sociopolitical structure in Siena contributed to an atmosphere of cultural resurgence in the west. Artistic expression in the commune and region began to flower again. The vision presented by the Sienese artists in general and Ambrogio Lorenzetti in particular attested to the ability of artists to guide the cultural vision of the west into the future. The concept of peace was part of that vision. It accompanied the redevelopment of the culture once the socio-political structures opened up to the necessity of the artistic structures in culture. And, one structure perhaps did not need to precede the other. They cleared the field for each other. When Lorenzetti pointed toward the painterly developments in western arthis representation of Peace-as Heinrich Wölfflin would define them, Lorenzetti may not have realized entirely what he was achieving. But he was seeing. He was not rendering what he saw only in the mode of his time. He rendered precisely the extent of what he saw. He could do this as a sanctioned Sienese artist because of the trust the Nine had placed in him. They had commissioned him. His stature in Siena's socio-political order assured him of a position where he could represent the depth of his historical period. He achieved a painterly depth in his frescoes that pointed as much to the edges of the Sienese 
contado as geographically possible in the bounds of his painting. Meanwhile, his achievement came in pointing his culture as far as he could and defining the shape of peace for his time and beyond into the next cultural period.

Where Lorenzetti had been able to record the re-establishment of the concept of peace into official western culture during an official time of peace and do so with a double focus on its socio-political potential as propaganda as well as its definition as representative of the development of culture for all citizens, Rubens achieved an effect during war that indicated the direction in which power brokers were leading nations was creating a western world that was not sustaining conditions under which the populace could thrive. Rubens was clearly in the forefront of artists who depicted conditions of horror leading to no workable solution for the culture. His extension of his period into the future of the art of the early-Modern era became visible in the upper-left corner of Horrors of War where just the simple addition of sky led the viewer's eye and emotional investment beyond the open door, causing the horrors in the intensified activity of the painting, to an opening where the horrors do not play. After the Treaty of Westphalia, the populace for whom Rubens spoke gained its voice culturally, evidenced in the relaxing of controls by the power brokers from which writers, such as, Thomas Hobbes and John Locke could emerge as voices of the popular thinking of the period.

Regarding the milieu of Rubens, Wölfflin wrote about the "Dutch pastures to which native artists have given the expression of the most widespread tranquility. But when Rubens handles these themes, the subject looks totally different: the earth rolls in vigorous waves, tree-trunks writhe passionately..." (6). In just this way, Wölfflin may have suggested that Rubens was giving expression to the undercurrents of the socio- 
political makeup of his era. For example, in The Horrors of War, Rubens wanted to communicate the unrestful nature of life during the Thirty Years' War. Rubens represented a populace that had little voice in its world until the Treaty of Westphalia. Wölfflin continued, "where the sense of form comes into immediate contact with spiritual and moral elements" (9) was precisely what operated in any period of time. For example, in the Siena period, Dante and Lorenzetti fashioned their creations nearly at the same time and organized their views of the world in which they lived, giving readers and viewers a recognizable portrait of the period as that portrait may have been emerging concurrently to its people.

Dante foresaw personal agency as capable of penetrating the malaise of time and setting differing standards. Peace of mind was achieved by penetration and a balance that even for a Hobbesian would have newly formulated what all feel and know. In this sense with Dante, as well as the Proust whom Arnold Hauser meets, literary artists could lead the people for whom they wrote. Literary artists have shaped the regional minds throughout the history of the culture. The culturally anticipatory qualities in Dante's Commedia were often missed even by $20^{\text {th }}$-century readers partly because of the distance between the era in which he wrote and the era in which they read. With Dante and Lorenzetti, there was a collective imperative emerging in how culture was addressed. Considering the mediation of meaning for a text, for example, as Arnold Hauser discussed Proust's dissolution of the work of art "in the stream of experiences, of time, of forgetting, and of remembering" begs the question could the experiences of the culture that dissolve in the expressions of art-as-purification have allowed the qualities of the definitions of peace to take hold and clarify themselves (503)? Was the quality there all 
along and did it then clarify itself over the centuries by necessity when articulated by the populace? The quality had something to do with its "continuously regenerating function" in the disjunction of the viewer between one historical period and another (502). The concept of peace developed through the efforts of the populace and the ideas and visions of its forward-thinking artists.

Hauser identified the power of the improvisation of ideas in culture. The power derived from the improvised ideas breaking the flow of history, causing a shift, sending the progress of the culture in another direction, which even though close to the original direction, differed from the original. Of course, one could describe the facts behind any shift, but the path that history logically predicted did not always become the path that history followed. A new direction was frequently the starting point of a new history. Thomas Kuhn writing in 1962 of scientific advances called such a new state-of-affairs paradigm shifts. Hauser agreed and wrote of similar developments in art. "This only starts when improvisations change into institutions and spontaneity functions within the limits of conventions. The first convention is the first institution, the first assured possession of mankind, and the foundation of its future history" (39). For the study of the development of the concept of peace, that first convention occurred in Rome as the Pax Romana. The subsequent historical periods involved in the development of the concept of peace formed equal crucibles in which the play of history and development of peace brought much pain.

When Hauser discussed the function of artworks, he would find himself aligned with Paul Ricoeur in which the re-enactment of history, here the experience of the history through the experience of the art, empathizes the viewer. Hauser wrote of Proust that 
"artistic experiences...change with a changed outlook on life and changing forms of existence" (501). The Lorenzetti frescoes communicated their essential character in the "practice" of being viewed in the period for which they were painted. The allegory panel, for example, filled the room with a communication of the significance of the Nine in their milieu, showing the line of their legitimacy existing and operating simultaneously on a spiritual and ethical as well as a historical and mythological level. The cardinal and theological Virtues denoted the heart and soul of the Nine's rule. The previous rulers, the 24 , and the cords of Justice connoted the ethical impetus and historical fact of inheritance for the Nine's rule. However, the figure of Peace was the locus of the prospect for the future and in this sense is the one figure in the painting that orients herself to the future. By inference she was the result of the rule of the Nine, the promise of their good government. The Rubens painting three centuries later was created in a period with a different artistic vision. By comparison the Horrors of War showed a thematic depiction of the rape of Europa with spatial depths conceptually unavailable to Lorenzetti even though Rubens obscured them mainly with the clash of forces devastating and helpless proving the horror of the destruction of civilization. By the time the west arrived at the early 1950s when Picasso painted his War and Peace murals, space elaborated a different conception entirely in comparison to other centuries. Picasso returned to a flatness reminiscent even of figures dancing around ancient pottery as well as shadowy figures one might have imagined in Plato's parable of the cave. Yet Picasso's paintings showed layered figures as if they appeared in different planes in a depth of field from front to back, rather than stacked from top to bottom as they would have been rendered in previous eras. In War, the figure of Peace related to depths as definite as the other figures 
appeared dreamlike. All the spiritual universe seemed contained in the Picasso murals. The lessons of the past were perhaps conjoined with the knowledge accumulated in the present of 1952, which led to Picasso's prayer for or meditation on Peace.

After the fall of Roman Empire, the fading of the depths of achievement in the western arts, especially architecture, sculpture, and poetry, as well as the art of sociopolitical organization, lasted for several centuries before the west began to recover its cultural depth. By the early-Renaissance, the depth began to return, its ascendancy visible in Florence and Siena both. In this dissertation the periods under scrutiny fell into two groups. Rome and Siena constituted the first group and exemplified an idea of order. (Actually Siena was the focus of that group with Rome serving as the commune's starting point and cultural model.) The two historical periods defined order, the creation and maintenance of order respectively, because their socio-political structures defined a topdown structure of influence. The second group, covering Westphalia and the $20^{\text {th }}-$ century, the Modern eras, epitomized an idea of development out of flux. According to the original organization of western societies, western culture simply was not structured to be renewed in such a way as to allow the voice of the people to express as much influence as it eventually did. But, there were political loosenings after the Treaty of Westphalia. Additionally the horrors of Modern war changed the hierarchies of the societies that made up western culture. The Westphalia period merely saw the beginnings of the change. After much struggle the $20^{\text {th }}$ century realized the change. Order in the Modern eras faced deep changes, hence, the use of the term, flux. The establishment of the United Nations sent the greatest signal that world changes were brewing. From that point, the west's focus on peace expanded and began to move from Europe to other parts 
of the world. In Europe the development of the concept of peace had seen peace movements come for 100 years. The concept of peace, however, now has other parts of the world in which to establish itself. The timing for those hopes is unknowable. It took 2,000 years or more to accomplish this development in the west.

Arnold Hauser's The Sociology of Art promoted the sense that the culture was able eventually to come to grips with its ability to fail utterly. "The blood of Grandet is stronger than Eugenie the individual," Hauser wrote of the structures that informed the daily existences of westerners, structures greater than individuals (10). The blood of the populace flowed strongly leading up to periods of peace, but in the Westphalia period Rubens' images declared this to be a flood that eventually would choke all bellicose efforts for the populace to continue. Rubens and Picasso, just as the creators of the ancient cave paintings, shared the expression of qualities of blood in their images, which approximated the reality of wars' effects on the human soul. T. S. Eliot's poems were all rooted to some geographical place to help him convey his sense of reality just as efforts at developing the concept of peace had been so rooted in order for them to work. After all, the wars fought by the west covered real ground. Western peace belonged to this ground as well as to western spirits. Although the ideas of peace and war ran parallel, they cancelled each other for centuries. The concept of peace yielded a tangible effort in order to match the destruction of war. That Eliot's Four Quartets all began in geography where the conceptual nature of time passing had its effect required that the concept of peace attach itself somehow to the earth in the throes of time, differing from Virgil who rooted The Aeneid to a single place. "Little Gidding," for example, harkened back to Dante who 
himself had rooted his own poem in levels of consciousness or existence on a spiritual earth, hell, and heaven. However, Dante's poem covered theoretical, emotional, and religious ground, in a way that suited the early Renaissance expressing the human soul in relation to spirit, rather than place.

Rubens and Picasso conveyed their periods' tales of the underlying attributes of struggle with the foreknowledge of a potential apocalypse, and broke open their emerging presences as if they had shells exposing all the inner workings of the relationships that keep war going forcing them to spill out in the light of the sun to whither and burn. In the dry heat of retribution that came with exposure to the eyes of the populace, governing forces no longer could extend their self-focused desire for conquest, destruction, and subjugation. Possibly these wars ended, once divined and emblematized, depicted magically as Hauser suggested, so that as images they opened to the eyes all the horrific cogs and wheels of war mechanisms. Then those machineries skipped and rusted into the obsolescence of faithlessness. These paintings exemplified Hauser's "artistic reflection of reality" (11). Their point was to capture and overcome the world they painted, the world the artists struggled to direct into a more complete whole. Their attempt offered the same undercurrent that appears in the motivation of all artists and writers who respond to their present with the force of an historical consciousness even though the consciousness may be driven emotionally in response to its being attuned to the anxieties of the culture.

It was the early-Modern era that exposed an awareness in the culture to the strength of the voice in the populace. Since that strength emerged with emotional power, it was easy to accept the case that artists such as Rubens could bring their messages to light before governments leading those events had wanted to receive those messages. 
Hauser noted that "Freud saw in art, as in neurosis, a failure to fit in with reality" (13). His were the words of a $20^{\text {th }}$-century consciousness, using late-Modern forms to depict problems that had grown even with the first stirrings of Modern thought. Certainly the painters did have a problem with reality. Otherwise, they would not have needed to overpower the images they witnessed, the events living in their own territory. Hauser went on to suggest artists compensate for the places they lacked in the social order.

If, however, we wish to follow precisely the process which resulted in the modern state of consciousness which at first rigidly separated the attitudes and then reunited them, we must go still further back into the prehistory of sociological self-consideration (Hauser 15-16).

Alienation had grown in differing ways throughout western history to the Modern eras and certainly this was true of Dante's Commedia. In Rome and Siena, though, art had served a propagandistic function for the power brokers, which differed from the function of art after Westphalia. Artistic creations served less practical purposes in the Modern eras. The lives lived in past eras had been lives that lacked qualities whose absence contributed to feelings of alienation. The populace had addressed the needs their stations in life lead them to, which opened a dialogue about mundane qualities of life that had never voiced themselves before Westphalia.

Picasso's images, for example, new at the time, provided an artistic rendering of just such a journey back into the $20^{\text {th }}$-century culture, but the feeling one got when seeing them was that they had been images resonating in our cultural minds perhaps since westerners dwelt in caves. The literature of the $20^{\text {th }}$ century, such as the Eliot poems, shared this quality as well. There was a sense of something elemental in the type of knowledge from which they drew. The effect was from a reduction to depictions of basic conceptions of thought and feeling. Dante and Lorenzetti in the pre-Modern era, drew 
from such knowledge relative to their historical period. Apparently Eliot and Picasso drew from cultural urges, as well, Ur-motivations available to the culture through a common understanding that was not easy to make explicit through either verbal or visual language. The experience of the devastation of the two world wars in the $20^{\text {th }}$ century had brought some to an experience of near-primitive life conditions.

Henry Van Dyke voiced the hopes of those who had wanted a "real pax humana" to come. (Fighting for Peace 236). But, a nationalistic pax was no peace. Nigel Young suggested it was arguable that there was a continuous peace movement at any point in history including the $20^{\text {th }}$ century. Rather, there was a variety of peace traditions to reconcile throughout Modern western history ("Peace Movements in History" 140). Of ideas on peace, it was Grotius who wrote "where the power of law ceases, there war begins" (Rights of War and Peace 75). S. C. Vestal's history of peace "deduced," as he wrote, "from a study of the history of nations," expressed the fact that "Europe, which has the greatest number of weak frontiers, is the scene of the worst wars in historical times" (The Maintenance of Peace 75). Of course, this point of view contradicted a cultural view of peace. The roots of the concept of peace that emerged in the culture over the centuries told how the civilization developed. Marsilius in the early-Renaissance had equated peace with a tranquility of order. If Europe had been the scene of the worst wars, the study of the development of the concept of peace from three periods of everdeepening debilitation from war prompted a new sense of how western civilization itself developed. The types of peace that emerged from the three eras accumulated to bring the western world to a point where it knew the stakes of world war, knew the capacity of 
science and technology to wage total war, and knew it must work to avoid that kind of war at all costs.

Western culture began to provide in its breaks from awful warfare the equivalent of a protective place for its people to endure. When the culture prosecuted great wars, though, it was

to the interest of all nations that each, within limits, should be adjusted to the conditions of an armed peace. Peace stays longest with those who are as careful to use their power justly as to show their determination not to submit to injustice.... If there is anything certain in human affairs, it is that valuable acquisitions are only to be retained by the continuation of the same energies which gained them, in kind if not in degree (Vestal 551).

Making his statement in 1920 , Vestal revealed the double-edged quality of the peace that emerged after World War I. One could sense in his words the inability for Europe, at that time, to stabilize peace. Vestal's use of the word acquisitions was significant since peace was not justly won or given. An armed peace, having become a fact of existence in the Modern world, created as many problems as it necessarily solved. Yet, at heart, Vestal's words contained a sense of how to lengthen peace by a careful use of power. There was nothing unexpected there, except the sense that peace was the foremost thought and drive in the culture and that determination itself appeared in the face of injustice. Given the organized care that the United Nations promised in the 1950s and beyond, a sense of justice seemed a possible hope. "The path to perpetual peace," Vestal wrote, "lies...in the mutual guarantee of territorial integrity and independence and equal rights" (555-556). At this particular point in the history of the west, the United Nations as an organization with promise was almost enough. "The goal is a world of people and nations in control of themselves from within by agreement and cooperation rather than controlled from outside themselves by threat, coercion, intimidation, and domination" (Cady 79-80). In order to 
maintain peace, a European nation's focus had to be internal and external simultaneously and that nation's efforts had to achieve a balance with those of other nations.

There were times when the concept of peace seemed to have developed itself by the 1950s in situations similar to its beginnings in the Roman empire as if it had made a cyclical return to those elements. In Siena, the Roman model had been superimposed on a small commune, essentially a city-state. The result was a commune using many grafted elements with the concept of peace being employed as propaganda to support the legitimacy of the ruling powers. In the Westphalia period, the model of one central European power governing many conquered populations had long disappeared with the Thirty Years' War making room for national populations that began to establish themselves as influential among the organization of nations and peoples. In the $20^{\text {th }}$ century, the social order fell prey to the accumulations of centuries of corrupt sociopolitical orders. By 1950, after the devastation of two world wars, the west had established an organization, the United Nations, that planned to collect the voices of the world's nations together to help influence the peaceful and organized direction of world events. In Europe, the beginnings of unity appeared. The non-nationalistic influence of the United Nations was dialogic and diplomatic, rather than militaristic, which offered a new approach to world order. Each historical era in the west had produced its own expressions that served the development of the concept of peace for its time. Even when the artistic evidence preceded the event that pinpointed an exact period within the purview of this dissertation, the art allowed the reader to view evidence of the ideas formulating themselves in the culture. One understood the perspectives of the society 
during crises and comprehended what type of thinking and what types of sensibilities lead a society to peace.

If this conclusion is in its initial stages positive, it is because in Europe and the world a framework has been established within which peace becomes more than just a concept. It became a useful pursuit, a developed necessity, which worked even though stumbling blocks to its progress were inevitable. Its progress continued along a parallel path with war, which according to Michael Howard was definitely inevitable, more so with each war humanity fought (9). The main question for Humanitarians has been to determine to what degree they are the same or different from the people of other ages in their kinship to the concept of peace. In the $20^{\text {th }}$ century, wars had reduced the culture to wondering if warfare was becoming the way of life in the culture. Ralph B. Potter offered this list of the just causes of war:

1) To protect the innocent from unjust attack.

2) To restore rights wrongfully denied.

3) To reestablish an order necessary for decent human existence (8).

Potter extended the thought to say a just cause is to be determined in wars (11-12). However, his assessment seems simplistic. The United Nations' effort at peace maintenance became complex. Maintenance added an entirely differed layer of thinking and action to the problem of determining whether a war was just.

For the purposes of this dissertation, one may accept the proposition that the concept of peace was developed when it reached the 1950s near the time of the founding of the United Nations. By no means, though, was the concept of peace finished in the world-at-large, but for the phase after which great wars had been prosecuted, one may say 
the concept of peace had developed. The social and political structures in the west could begin to work together to maintain peace. Discussions of peace from that point on had to include the United Nations as a pivotal organization in the solution of world problems, sometimes even as a factor exacerbating the problems inherent in solutions. The concept of peace had taken 2,000 years to develop in the west. That model may not be easily transferable to other parts of the world in the post-2001 world. Yet, there are echoes today of the same relationship between the populace and power brokers that this dissertation has discussed. As such, one remembers George Santayana's warning, "those who cannot remember the past are condemned to repeat it" (284). One may rightly infer from reading this dissertation that it presents an alternate view of artistic evidence in the service of reminding the west that the maintenance of peace requires a great deal of work. However, the United Nations stands while the voice of the populace all over the world becomes more audible to more ears in the developed world. 


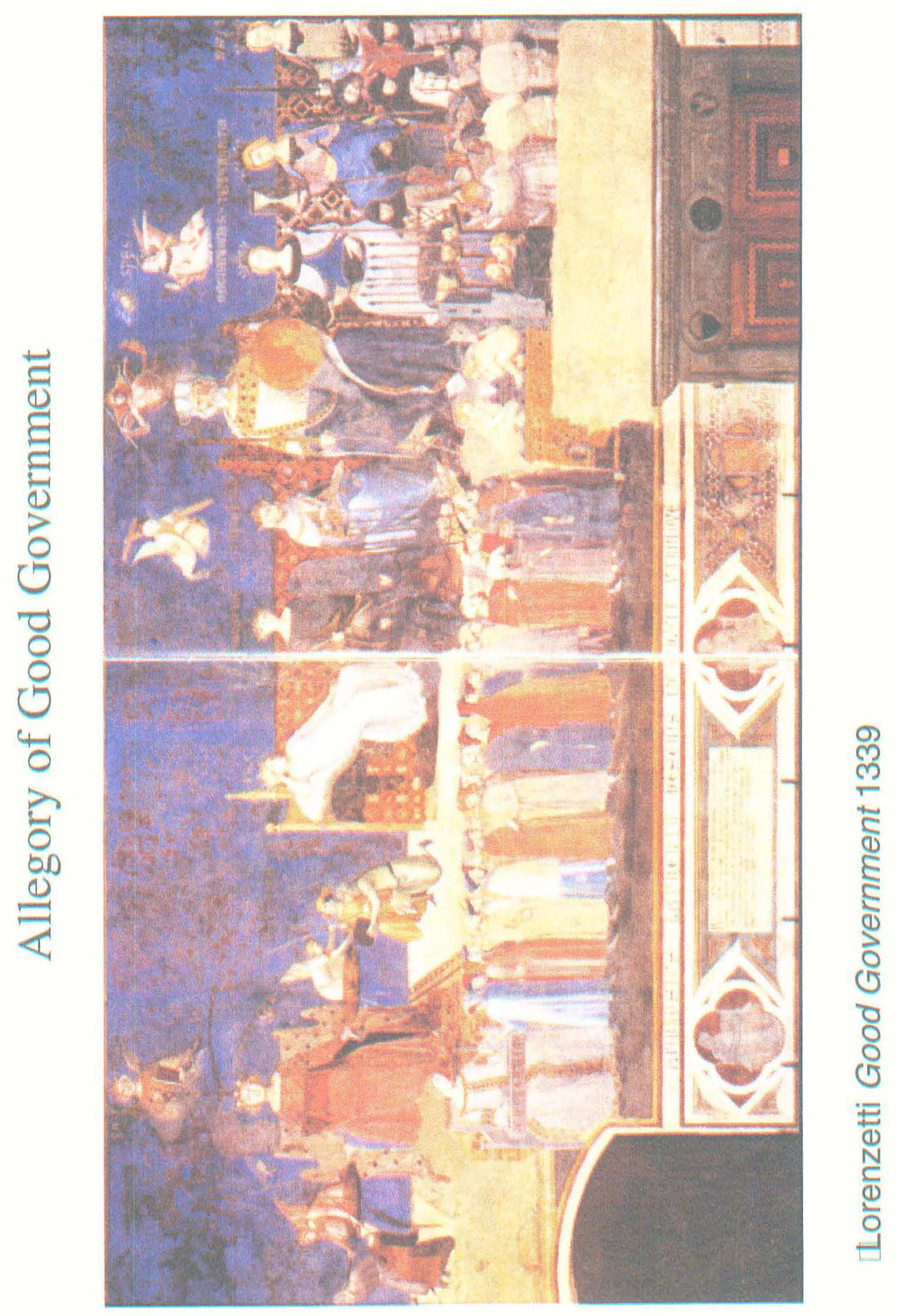




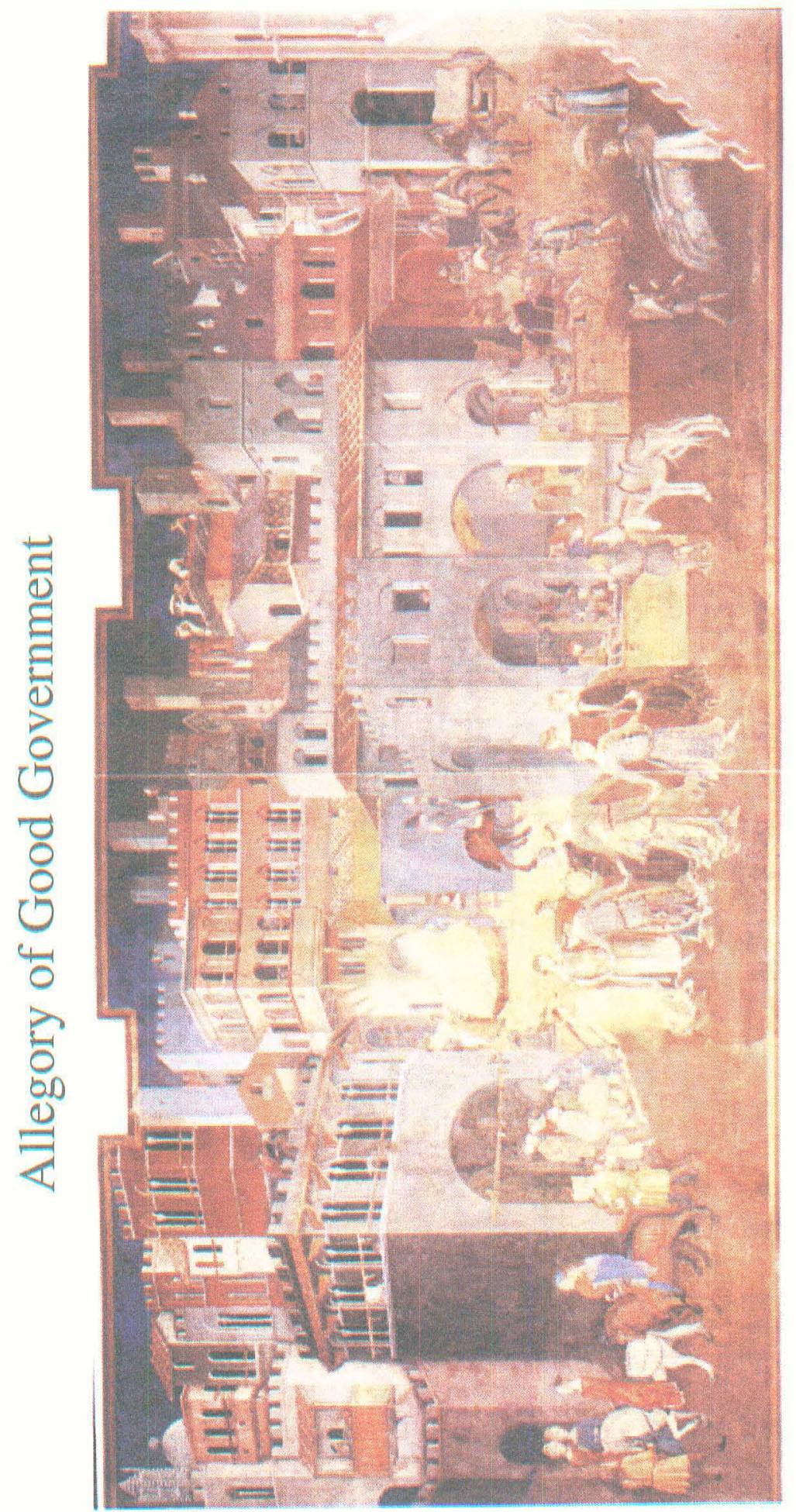

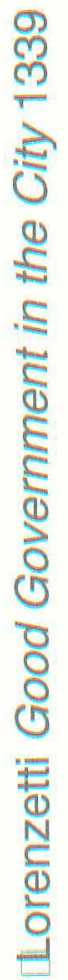




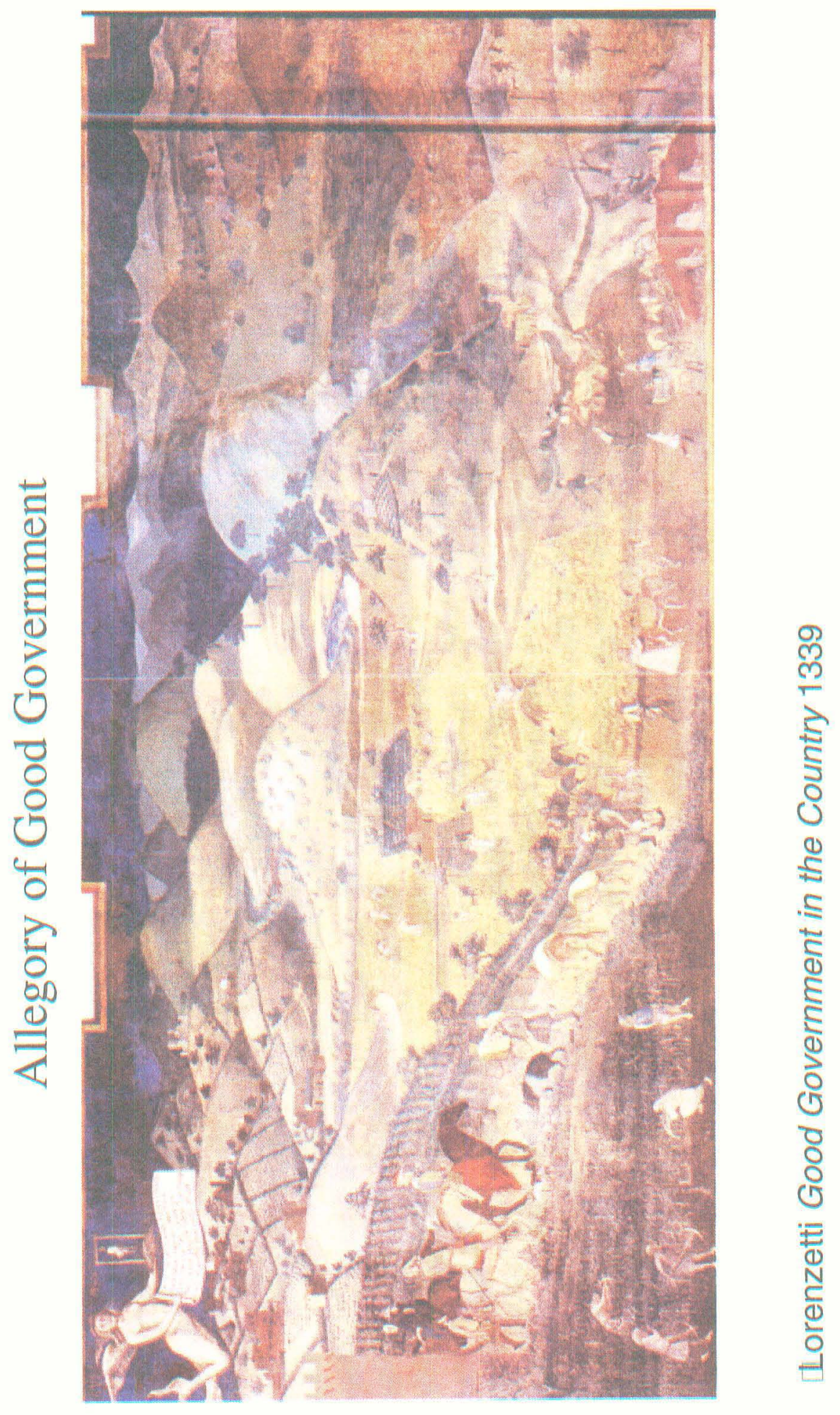




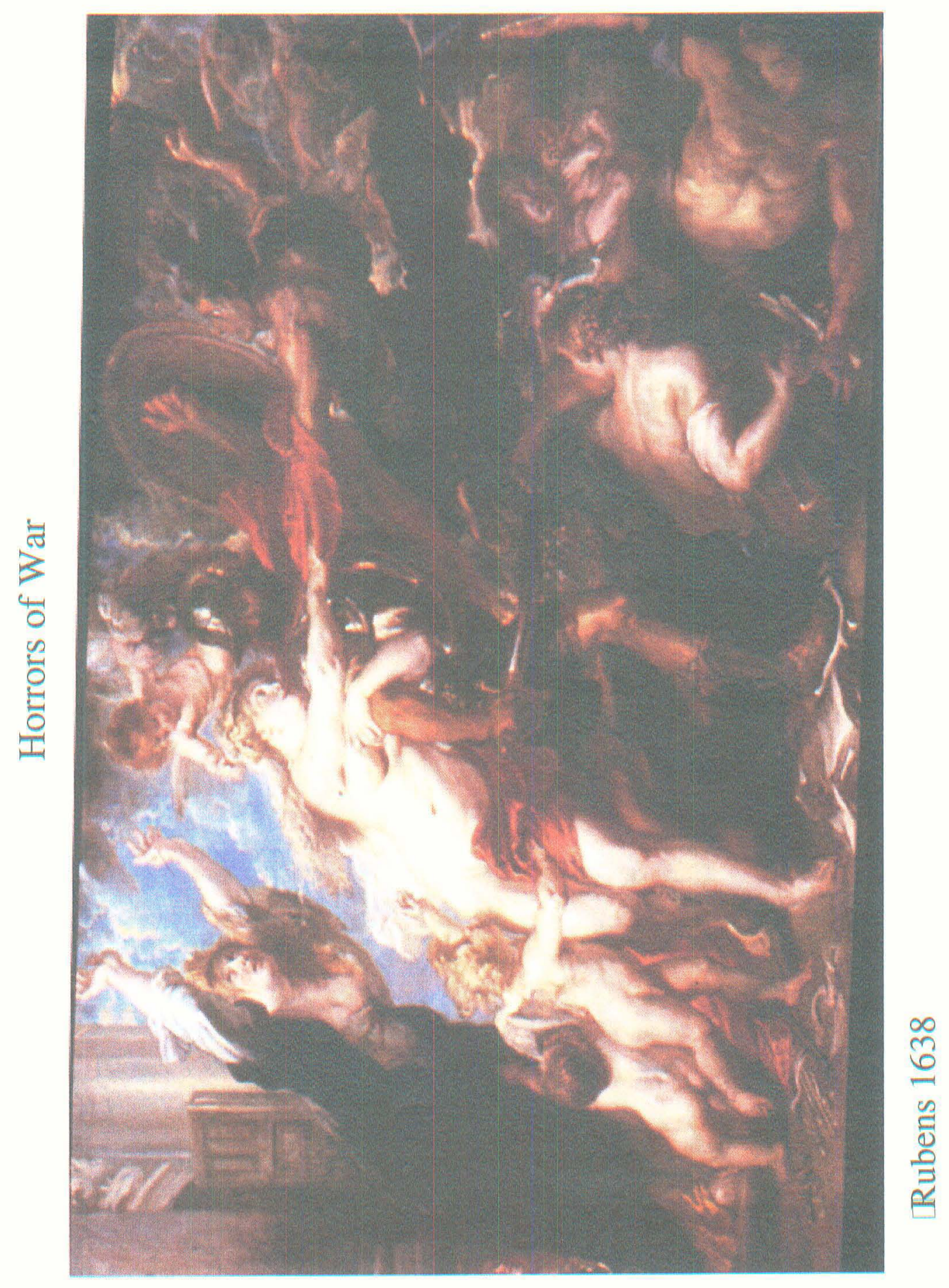




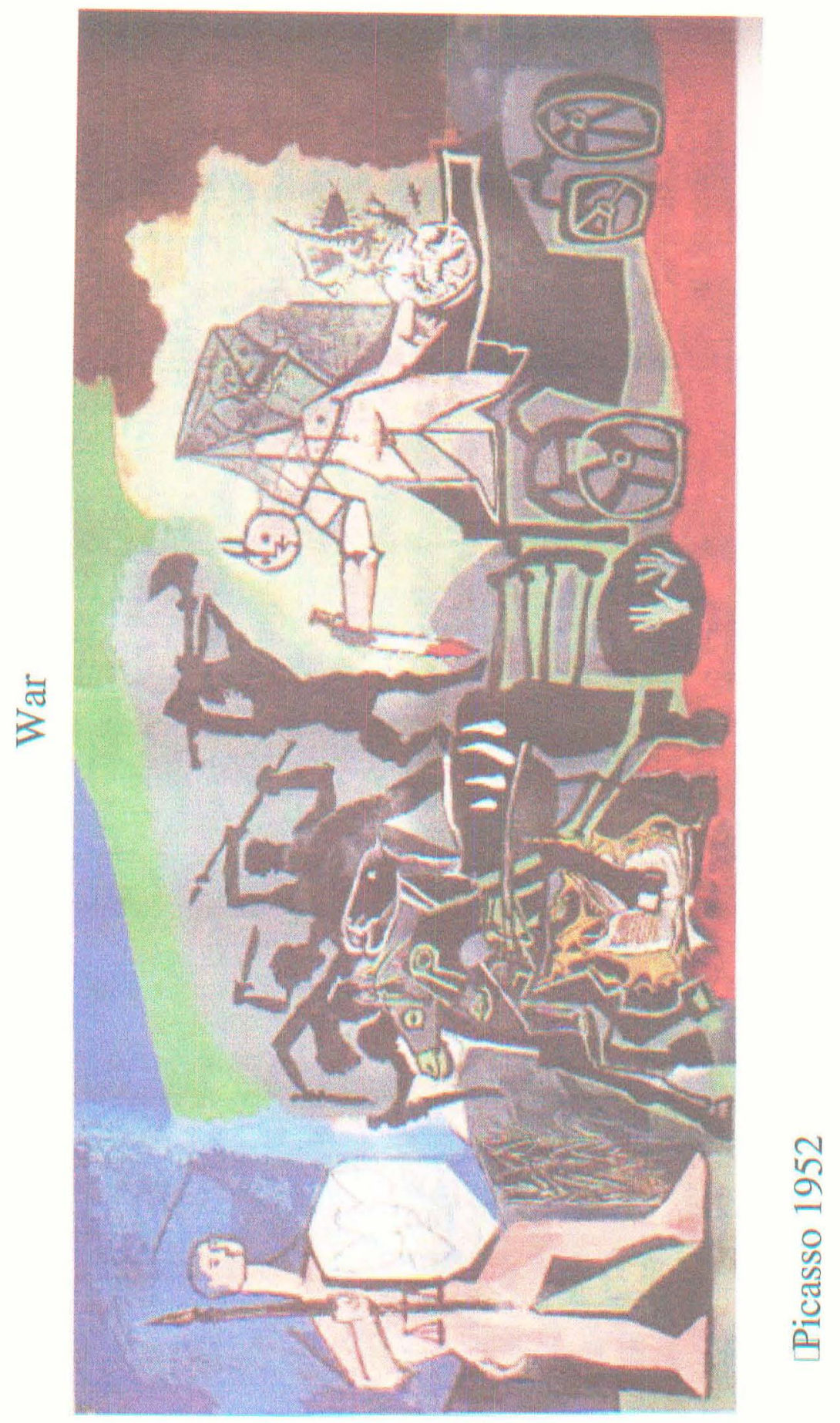




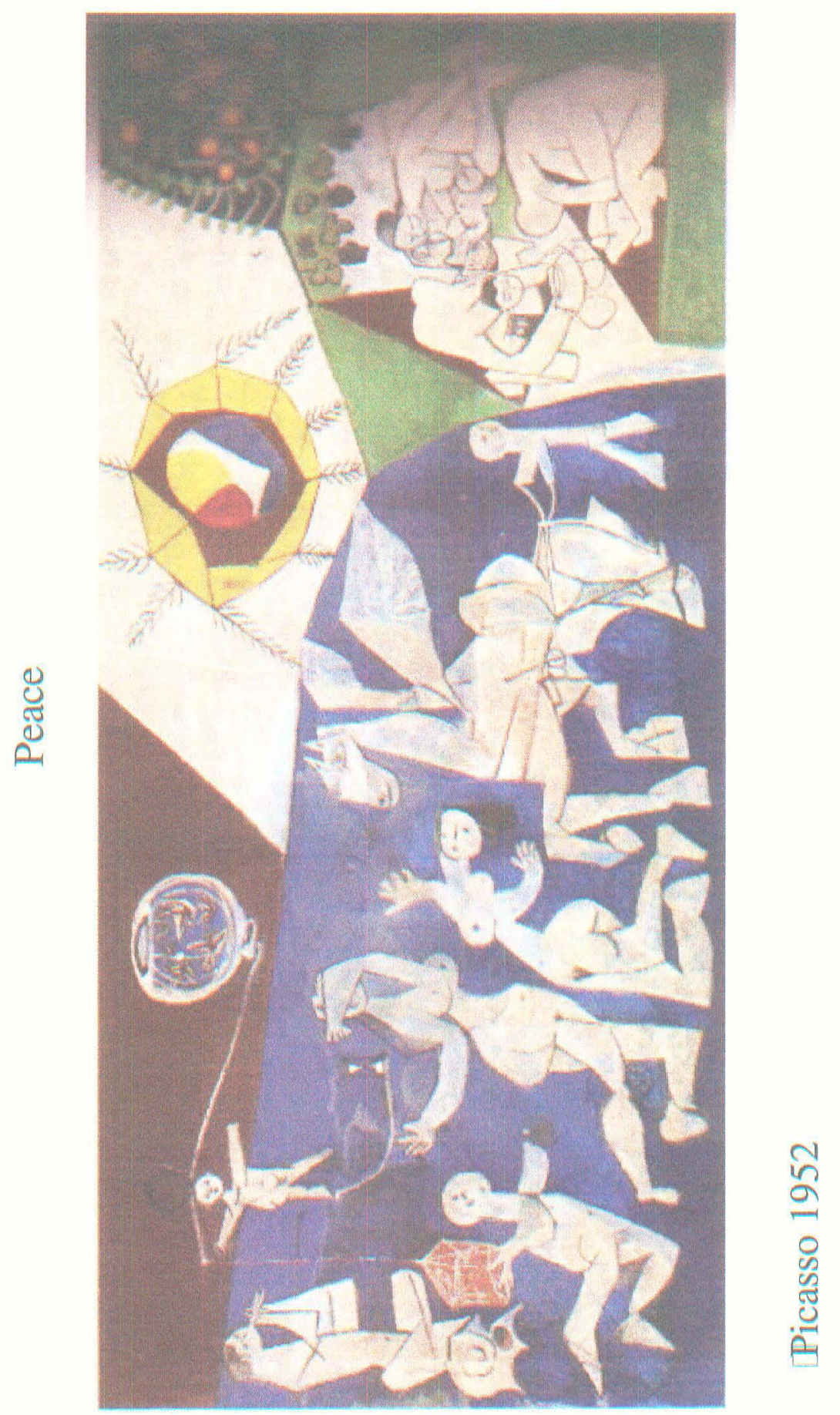




\section{REFERENCES}

Abrams, Irwin, ed. Nobel Lectures: Peace 1996-2000. London: World Scientific, 2005.

Adams, Laurie Schneider. Italian Renaissance Art. Boulder: Westview Press, 2001. 4850.

Alighieri, Pietro. "Dante's Seven Kinds of Meaning 1337-1340" in Dante: The Critical heritage: 1314(?)-1870. ed. Michael Caesar. New York: Routledge, 1989, 133 137.

Andersen, Wayne. The Ara Pacis of Augustus and Mussolini: An Archaeological Mystery. Boston: Editions Fabriart, 2003.

Anderson, James C. The Historical Topography of the Imperial Fora. Bruxelles: Latomus, 1984.

Anderson, William S. The Art of The Aeneid. Englewood Cliffs, N. J.: Prentice-Hall, Inc., 1969.

Barnet, Richard J. "The Illusion of Security." In Peace and War. San Francisco: W. H. Freeman and Company, 1973. pp. 275-287.

Baudouin, Frans. Piero Paulo Rubens. New York: Harry N. Abrams, Inc., 1977.

Beitz, Charles R. and Theodore Herman, eds. Peace and War. San Francisco: W. H. Freeman and Company, 1973.

Belkin, Kristin Lohse. Rubens. London: Phaidon, 1998. 278-294.

Benjamin, Walter. Illuminations. New York: Harcourt, Brace and World, 1968. 
Bertman, Stephen. Art and the Romans: A Study of Roman Art as a Dynamic Expression of Roman Character. Lawrence, Ka.: Coronado Press, 1975.

Blunt, Anthony. Picasso's “Guernica." New York: Oxford University Press. 1969.

Bok, Sissela. A Strategy for Peace. New York: Pantheon Books, 1989.

Bowsky, William M. A Medieval Italian Commune: Siena under the Nine, 1287-1355. Berkeley: University of California Press, 1981.

Boyle, A. J. "Reading Flavian Rome" in Flavian Rome: Culture, Image, Text. Edited by A. J. Boyle and W.J. Dominik. Boston: Brill, 2003. 1-67.

Briand, Auguste. "Briand Calls for the Creation of a European Union," The League of Nations. Geneva, Switzerland. Sixth Meeting 5 September 1929. 49-53. $<$ http://webapp 1.dlib.indiana.edu/collections/lonun/league_era/briand/docs/briad002.pdf >

Brunk, Conrad. "Shaping a Vision: The Nature of Peace Studies." In Patterns of Conflict, Paths to Peace. Edited by Larry Fisk and John Schellenberg, Orchard Park, N. Y.: Broadview Press, 2000.

Cady, Duane L. From Warism to Pacifism: A Moral Continuum. Philadelphia: Temple University Press, 1989.

Caesar, Michael, ed. Dante: The Critical Heritage: 1314(?)-1870 New York: Routledge, 1989.

Caferro, William. Mercenary Companies and the Decline of Siena. Baltimore: Johns Hopkins University Press, 1998.

Cairola, Aldo. Il Palazzo Pubblico di Siena. Roma: Editalia, 1963. 
Campbell, C. J. "The City's New Clothes: Ambrogio Lorenzetti and the Poetics of Peace." The Art Bulletin v. 83 no. 2 (June 2001) p. 240-58.

Carr, Craig L. and Michael J. Seidler. "Pufendorf, Sociality and the Modern State." History of Political Thought, 17, 1996, 354-378.

Carr, Craig L. ed. The Political Writings of Samuel Pufendorf. New York: Oxford University Press, 1994.

Catt, Carrie Chapman, Jane Addams, et al. Why Wars Must Cease. New York: The MacMillan Co., 1935.

Cecil, L. "Economics of Peace and War Provisions-Germany's Economic Efforts in Behalf of Armament Before." The Journal of Modern History. 43.2, 1971, 336338.

Cicero, De Officiis. Cambridge: Harvard University Press, 1956.

Curtius, E. R. Essays on European Literature. Princeton: Princeton University Press, 1973.

Dante. De Monarchia in The Portable Dante. New York: The Viking Press, 1971.

Dante. The Divine Comedy. tr. Laurence Binyon in The Portable Dante. New York: The Viking Press, 1971.

Dante. The Inferno. tr. Robert Pinsky. New York: Farrar, Straus and Giroux, 1994.

Danto, Arthur. The Madonna of the Future: Essays in a Pluralistic Art World. New York: Farrar, Strauss and Giroux, 2000.

Davies, Norman. Europe: A History. New York: Oxford University Press, 1996.

Despland, Michel. Kant on History and Religion. Montreal: McGill-Queen's University Press, 1973. 
Donoghue, Denis. “On 'Burnt Norton”” in Lobb, Edward. Words in Time: New Essays on Eliot's Four Quartets. Ann Arbor: University of Michigan Press, 1993. 1-19.

Dudley, Donald. Urhs Roma. Aberdeen: Phaidon, 1967.

Einstein, Albert and Sigmund Freud, "Why War?" in The Standard Edition of the Complete Psychological Works of Sigmund Freud, Volume XXII (19.32-1936) New Introductory Lectures on Psycho-Analysis and Other Works. James Strachy, Gen. Ed., London: The Hogarth Press, 1964.

Eliot, T.S. Four Quartets. New York: Harcourt, Brace and World, Inc., 1971.

Elsner, Jas. Art and the Roman Viewer: The Transformation of Art from the Pagan World to Christianity. New York: Cambridge University Press, 1995.

Fahey, J. L. "The Path to Peace." The Humanist v. 64 no. 4 (July/August 2004). p. 6, 46.

Feller, Gordon, Sherle R. Schwenninger and Diane Singerman, eds. Peace and World Order Studies: A Curriculum Guide. New York: Transnational Academic Program, Institute for World Order, 1981.

Fichte, J. G. Foundations of Natural Right: According to the Principles of Wissenschafteslehre. New York: Cambridge University Press, 2000.

Foucault, Michel. "The Discourse on Language." in The Archaeology of Knowledge and The Discourse on Language. New York: Pantheon Books, 1972.

Frankl, Viktor E. Man's Search for Meaning. New York: Pocket Books, 1984.

Freccero, John. "Foreword" in Dante. The Inferno. tr. Robert Pinsky. New York: Farrar, Straus and Giroux, 1994.

Frugoni, Chiara. A Distant City: Images of the Urban Experience in the Medieval World. Princeton, N.J.: Princeton University Press, 1991. 
Galinsky, Karl. Augustan Culture: An Interpretive Introduction. Princeton: Princeton University Press, 1996.

Gandhi, Mohandas K. "On Nonviolence." In Peace and War. San Francisco: W. H. Freeman and Company, 1973. pp. 345-348.

Gaskin, J. C. A. "Introduction" in The Leviathan. Thomas Hobbes. New York: Oxford University Press, 1996. xi-xliii.

Gerould, James Thayer, ed. Selected Articles on The Pact of Paris: Officially the General Pact for the Renunciation of War. Freeport, New York: Books for Libraries Press, 1972.

Grotius, Walter. Rights of War and Peace. New York: M. Walter Dunne, 1901.

Haakonssen, Knud. "Hugo Grotius and the History of Political Thought." Political Theory, 13, 1985, 239-265.

Haakonssen, Knud. Grotius, Pufendorf and Modern Natural Law. Brookfield, VT: Ashgate Publishing Company, 1999.

Hammond, Mason. The Augustan Principate: In Theory and Practice During the JulioClaudian Period. Cambridge, MA: Harvard University Press, 1933.

Hannestad, Neils. Roman Art and Imperial Policy. Hajbjerg: Jutland Archaeological Society, 1986.

Hartt, Frederick and David G. Wilkins. History of Italian Renaissance Art: Painting, Sculpture, Architecture. New York: Harry N. Abrams, Inc. 2003. 143-149.

Hauser, Arnold. The Sociology of Art. Chicago: University of Chicago Press, 1982. Herman, Sondra R. Eleven Against War: Studies in American Internationalist Thought, 1898-1921. Stanford: Stanford University Press, 1969. 
Herr, Michael. "Dispatches." In Reporting Vietnam, Part Two: American Journalism 1969-1975. New York: The Library of America, 1998. pp. 555-764.

Hill, David. "The Work and Influence of Hugo Grotius." Grotius, Walter. Rights of War and Peace. New York: M. Walter Dunne, 1901. 1-16.

Hobbes, Thomas. The Leviathan. New York: Oxford University Press, 1996.

Howard, Michael. The Invention of Peace: Reflections on War and International Order. Yale University Press, 2000.

Hughes, A. “Naming the Unnameable: An Iconographical Problem in Rubens's Peace and War." The Burlington Magazine v. 122 (March 1980) p. 157-63+.

Kant, Immanuel. "Idea for a Universal History with Cosmopolitan Intent." In The Philosophy of Kant, ed. by Carl J Friederich. New York: The Modern Library, 1949. 116-131.

Kant, Immanuel. Perpetual Peace. Boston: The World Peace Foundation, 1914.

Kant, Immanuel. Perpetual Peace. New York: Garland Publishing, Inc., 1972.

Keen, Kirsten Hoving. "Picasso's Communist Interlude: the Murals of War and Peace." The Burlington Magazine v. 122 (July 1980) p. 464-70.

Kettering, Alison McNeil. Gerard ter Borch and the Treaty of Münster. The Hague: Waanders Publishers, 1998.

Kiernan, Anna, ed. Voices for Peace. London: Scribner, 2001.

Klein, Robert. Form and Meaning: Essays on Renaissance and Modern Art. New York: Viking Press, 1979.

Langer, Herbert. The Thirty Years' War. Poole: Blandford Press, 1978. 
Leal, Brigitte, Christine Piot, Marie-Laure Bernadac. The Ultimate Picasso. New York: Harry N. Abrams, 2000.

Leuschner, E. "Picturing Rubens Picturing: Some Observations on Giordano's 'Allegory of Peace' in the Prado [sources for the Madrid painting]." Gazette des Beaux-Arts v. ser6 no. v129 (May/June 1997) p. 195-206.

Levi, Primo. The Reawakening New York: Touchstone, 1995.

Lobb, Edward. Words in Time: New Essays on Eliot's Four Quartets. Ann Arbor: University of Michigan Press, 1993.

Locke, John. Two Treatises of Government and A Letter Concerning Toleration. New Haven: Yale University Press, 2003.

Lorenz, Konrad. On Aggression. New York: Bantam Books, 1969.

Lowe, Ben. Imagining Peace: A History of Early English Pacifist Ideas, 1340-1560. University Park, Pennsylvania: The Pennsylvania State University Press, 1997. Magurn, Ruth Saunders, ed. The Letters of Peter Paul Rubens. Cambridge, MA: Harvard University Press, 1955. 408-409.

Mansilla, Luis M. "Viaggio in Italia: Asplund e Kahn: Due Vedute di Siena e Una Passeggiata per lo Sguardo"/"Two Views of Sienna and a Stroll for the Gaze." Casabella 66 (2002): 88-97.

Marsilius, of Padua. Marsilius of Padua, The Defender of Peace: The Defensor Pacis. translated with an introduction by Alan Gewirth. New York: Harper \& Row, 1967.

Mathias, Albert and Tanja Kopp-Malek. "The Pragmatism of Global and European Governance: Emerging Forms of the Political 'Beyond Westphalia'. Millennium- 
Journal Of International Studies 31 (3), 2002, 453-471.

Matthews, Roy T. and F. DeWitt Platt. The Western Humanities, Fifth Edition. New York: McGraw Hill, 2004.

Mayer, John T. T. S. Eliot's Silent Voices. New York: Oxford University Press. 1989.

Mazzotta, Giuseppe. Dante's Vision and the Circle of Knowledge. Princeton, N. J.:

Princeton University Press, 1993.

Mee, Charles L., Jr. The End of Order: Versailles 1919. New York: E. P. Dutton, 1980.

Mellor, Ronald. "The New Aristocracy of Power" in Flavian Rome: Culture, Image,

Text. Edited by A. J. Boyle and W.J. Dominik. Boston: Brill, 2003. 69-101.

Mendlovitz, Saul H. and R. B. J. Walker, eds. Towards a Just World Peace: Perspectives from Social Movements. Boston: Butterworths, 1987.

Michel, Emile. Rubens: His Life, His Work, and His Time. New York: Charles Scribner's Sons. 1899.

Milano, Paolo. "Editor's Introduction," in Dante. The Divine Comedy. tr. Laurence Binyon in The Portable Dante. New York: The Viking Press, 1971.

Milosz, Czeslaw. New and Collected Poems (1931-2001). New York: Ecco, 2001.

Momen, M. “The Politics of Peace-Maintenance.” The International Journal of Conflict Management. 11.3, 2000, 290-294.

Nâbî, "In the Garden of Time and Destiny," excerpted in World Poetry, Katharine Washburn and John S. Major, Eds. Clifton Fadiman, General Editor. New York: W. W. Norton and Company, 1998.

Nathan, Otto and Heinz Norden, eds. Einstein on Peace. New York: Simon and Schuster, 1960. 
Nhema, A. G. The Quest for Peace in Africa: Transformations, Democracy, and Public Policy. Addis Ababa: Ossrea, 2004.

Noreña, Carlos F. "Medium and Message in Vespasian's Templum Pacis." Memoirs of the American Academy in Rome 48, 2003. 25-43.

Norman, Diana. Painting in Late Medieval and Renaissance Siena (1260-1555). New Haven: Yale University Press, 2003. 98-104.

Norman, Dorothy, ed. Nehru: The First Sixty Years, Volume II. New York: The John Day Company, 1965.

Oppenheimer, Paul. Rubens A Portrait: Beauty and the Angelic. London: Gerald Duckworth and Co., Ltd., 1999.

Panofsky, Erwin. Meaning in the Visual Arts. Garden City, NY: Doubleday Anchor, 1955.

Paris, Roland. At War's End: Building Peace After Civil Conflict. New York : Cambridge University Press, 2004.

Parker, Geoffrey. The Thirty Years' War. New York: Routledge, 1984.

Penrose, Sir Roland. Picasso: His Life and Work. Berkeley: University of California Press, 1981.

Perry, Ellen. The Aesthetics of Emulation in the Visual Arts of Ancient Rome. New York: Cambridge University Press, 2005.

Polisensky, J. V. War and Society in Europe 1618-1648. New York: Cambridge University Press, 1978. 
Polzer, Joseph. “Ambrogio Lorenzetti’s War and Peace Murals Revisited: Contributions to the Meaning of the Good Government Allegory." Artibus et Historiae v. 23 no. 45 (2002) 63-105.

Pollard, A. F. Factors in Modern History. London: Constable \& Company, Ltd., 1932.

Potter, Ralph B., Jr. "The Moral Logic of War." In Peace and War. San Francisco: W. H. Freeman and Company, 1973. pp. 7-16.

Pufendorf, Samuel. The Whole Duty of Man, According to the Law of Nature. Indianapolis: Liberty Fund, 2003.

Reid, Julian. “Deleuze's War Machine: Nomadism Against the State." MillenniumJournal Of International Studies 32 (1), 2003, 57-87.

Rolland, Romain. Above the Battle. Chicago: The Open Court Publishing Company, 1916.

Rosenthal, L. "Manhood and Statehood: Rubens's Construction of Heroic Virtue." Oxford Art Journal v. 16 no. 1 (1993) p. 92-111.

Rousseau, Jean-Jacques. The Confessions of Jean-Jacques Rousseau. New York: The Modern Library, 1945.

Rousseau, Jean-Jacques. The Social Contract. New York: Penguin Books, 1968.

Salmon, J. H. M. Cardinal de Retz: The Anatomy of a Conspirator. London: Weidenfeld and Nicolson, 1969.

Santayana, George. Life of Reason: Reason in Common Sense. New York: Scribners, 1905.

Schevill, Ferdinand. History of Florence: from the Founding of the City through the Renaissance. New York: Frederick Ungar Publishing Co., 1961. 
Schevill, Ferdinand. Siena, The Story of a Mediaeval Commune. New York: Scribner's Sons, 1909.

Shapiro, Ian. "John Locke's Democratic Theory" in Two Treatises of Government and A Letter Concerning Toleration by John Locke. New Haven: Yale, 2003 (309-340). Shotwell, James T. War as an Instrument of National Policy and its Renunciation in the Pact of Paris. New York: Harcourt, Brace and Company, 1929.

Sonnino Paul. From D’Avaux To Devot: Politics And Religion In The Thirty Years War. History 87 (286), April 2002, 192-203.

Southard, Edna Carter. The Frescoes in Siena's Palazzo Pubblico, 1289-1539: Studies in Imagery and Relations to Other Communal Palaces in Tuscany. New York: Garland Pub., 1979.

Strong, D. E. Roman Imperial Structure: An Introduction to the Commemorative and Decorative Sculpture of the Roman Empire Down to the Death of Constantine. London: Alec Tiranti, 1961.

Tacitus, Cornelius. Agricola Germania Dialogus. Cambridge, MA: Harvard University Press, 1970. 25-115.

Tacitus. The Histories. New York: Modern Library, 2003.

Tankard, Alice Doumanian. Picasso's Guernica after Rubens Horrors of War: A Comparative Study in Three Parts-Iconographic and Compositional, Stylistic, and Psychoanalytic. Philadelphia: Art Alliance Press, 1984.

Tarar, Ahmer. "Diversionary Incentives and the Bargaining Approach to War." International Studies Quarterly 50, 2006, 169-188. 
Thornbury, Charles. "Introduction" in John Berryman Collected Poems 1937-1971. New York: The Noonday Press, 1989. xvii-lix.

Toynbee, J. M. C. The Art of the Romans. New York: Frederick A. Praeger, 1965.

Van Dyke, Henry. Fighting for Peace. New York: Charles Scribner's Sons, 1917.

Vasquez, John A. "The Probability of War, 1816-1992." International Studies Quarterly $48,2004,1-27$.

Vestal, S. C. The Maintenance of Peace or the Foundations of Domestic and International Peace as Deduced from a Study of the History of Nations. New York: G. P. Putnam's Sons, 1920.

Virgil, Georgics, excerpted in World Poetry, Katharine Washburn and John S. Major, Eds. Clifton Fadiman, General Editor. New York: W. W. Norton and Company, 1998.

Virgil, The Aeneid. New York: Random House, 1983.

Waley, Daniel Philip. Siena and the Sienese in the Thirteenth Century. New York: Cambridge University Press, 1991.

Wallace-Hadrill, 1988, 69-77. "The Social Structure of the Roman House." Papers of the British School at Rome 56 (1988), pp. 43-97.

War Reports of General of the Army George C. Marshall, General of the Army H. H. Arnold, Fleet Admiral Ernest J. King, The. Philadelphia: J. B. Lippincott, 1947. Watts, Derek A. Cardinal de Retz: The Ambiguities of a Seventeenth-Century Mind. New York: Oxford University Press, 1980.

Wedgwood, C. V. The Thirty Years' War. London: Jonathon Cape, 1944. 
Wepplman, S. "Spinello Aretino's Canonization of Thomas Becket and Trecento

Drawing Practice." Master Drawings v. 41 no. 1 (Spring 2003) p. 3-13.

White, John. Art and Architecture in Italy 1250-1400. New Haven: Yale University

Press, 1993. "Control and Casualness in Lorenzetti's Depiction of the

Government and the City."

Williams, Bernard. Shame and Necessity. Berkeley: University of California Press, 1993.

Wilson, Woodrow. President Wilson's State Papers and Addresses, with Editorial Notes, a Biographical Sketch, an Introduction and an Analytical Index. New York: The Review of Reviews Company, 1918.

Windolph, F. Lyman. Leviathan and Natural Law. New York: Greenwood Press, 1951.

Wokler, Robert. “Rousseau's Pufendorf: Natural Law and the Foundations of Commercial Society." History of Political Thought, 15, 1994, 373-402.

Wölfflin, Heinrich. Principles of Art History: The Problem of the Development of Style in Later Art. Mineola, NY: Dover Publications, 1950.

Xenias, Anastasia. "Can a Global Peace Last Even if Achieved? Huntington and the Democratic Peace." International Studies Review 7, 2005, 357-386.

Young, Nigel. "Peace Movements in History." In Towards a Just World Peace:

Perspectives from Social Movements. Saul H Mendlovitz and R. B. J. Walker, eds. Boston: Butterworths, 1987. pp. 141-151.

Zampaglione, Gerardo. The Idea of Peace in Antiquity. Notre Dame: University of Notre Dame Press, 1973. 
Zepp-LaRouche, Helga, “A Precedent for Peace in the Balkans: The Peace of Westphalia," to the EIR Seminar, 5 May 1999. The Schiller Institute.

http://www.schillerinstitute.org/strategic/hzl t of w $0599 . \mathrm{html}$. 


\section{CURRICULUM VITA}

NAME: $\quad$ Allan Berry McGuffey

ADDRESS: 3023 Curran Road

Louisville, KY 40205

DOB: $\quad$ Louisville, KY_19 August 1952

EDUCATION

\& TRAINING: $\quad$ B. A. Humanities (with Honors)

University of Louisville

1970-1973

M. A. Humanities

University of Louisville

1980-1982

Ph. D. English Rhetoric and Composition (incomplete - ABD)

University of Louisville

1983-1986

Ph. D. Humanities

University of Louisville

2004-2007

AWARDS: Graduate Dean's Citation

1982

Departmental Service Award

1981

PROFESSIONAL SOCIETY: Golden Key 